\title{
EDUCAÇÃO AMBIENTAL EM EMPRESAS DO SETOR FLORESTAL NO BRASIL
}

\author{
MÁRCIA CELESTINO MACEDO \\ Engenheiro Agrônomo
}

Orientador: Prof. Dr. DALCIO CARON

\begin{abstract}
Dissertação apresentada à Escola Superior de Agricultura "Luiz de Queiroz", Universidade de São Paulo, para obtenção do titulo de Mestre em Recursos Florestais, com opção em Conservação de Ecossistemas Florestais.
\end{abstract}

\author{
PIRACICABA \\ Estado de São Paulo - Brasil \\ Abril - 2002
}




\section{ERRATA}

MÁRCIA CELESTINO MACEDO. Educação Ambiental em empresas do setor florestal no Brasil

\begin{tabular}{|l|l|l|l|l|}
\hline p. & item & linha & Onde se lê & Leia-se \\
\hline vii & Sumário & décima & 4.1 .3 Número de... & 4.1 .2 Número de... \\
\hline vii & Sumário & décima segunda & 4.1 .5 Elaboração... & 4.1 .3 Elaboração... \\
\hline vii & Sumário & décima terceira & 4.1 .6 Público alvo... & 4.1 .4 Público alvo... \\
\hline vii & Sumário & décima quinta & 4.1 .7 Continuidade... & 4.1 .5 Continuidade... \\
\hline vii & Sumário & décima sétima & 4.1 .10 Atividades... & 4.1 .6 Atividades... \\
\hline vii & Sumário & décima oitava & 4.1 .11 Certificação & 4.1 .7 Certificação \\
\hline 11 & $\begin{array}{l}\text { Revisão de } \\
\text { Literatura }\end{array}$ & décima nona & $\ldots$ ECO-92,... & $\begin{array}{l}\text { Nonferência das } \\
\text { Meio Ambiente e }\end{array}$ \\
\hline 63 & 4.1 & $\begin{array}{l}\text { Desenvolvimento } \\
\text { ECO-92).... }\end{array}$ \\
\hline 67 & 4.1 & décima quinta & 4.1 .3 Número de... & 4.1 .2 Número de... \\
\hline 72 & 4.1 & décima quarta & 4.1 .5 Elaboração... & 4.1 .3 Elaboração... \\
\hline 78 & 4.1 & décima sétima & 4.1 .6 Público alvo... & 4.1 .4 Público alvo... \\
\hline 81 & 4.1 & décima quarta & 4.1 .7 Continuidade... & 4.1 .5 Continuidade... \\
\hline 85 & 4.1 & sétima & 4.1 .10 Atividades... & 4.1 .6 Atividades... \\
\hline
\end{tabular}

Incluir na página 125 a referência bibliográfica:

CASCINO, Fabio. Educação Ambiental: princípios, história, formação de professores. São Paulo: SENAC, 1999. 109 p. 
Dados Internacionais de Catalogação na Publicação (CIP) DIVISĀO DE BIBLIOTECA E DOCUMENTAÇĀO - ESALQ/USP

Macedo, Márcia Celestino

Educação ambiental em empresas do setor florestal no Brasil / Márcia Celestino Macedo. - - Piracicaba, 2002.

$130 \mathrm{p}$.

Dissertaçāo (mestrado) - - Escola Superior de Agricultura Luiz de Queiroz, 2002.

Bibliografia.

1. Administração florestal 2. Certificação florestal 3. Educação ambiental 4. Empresa agricola I. Título

CDD 333.707

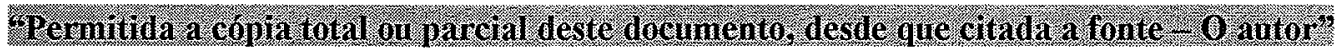


À minha filha Lara,

Alegria constante em minha vida.

Aos meus pais Humberto e Dorvalina, Presença, amor e incentivo.

Ao Ro6son (in memorian),

Que vivia tudo intensamente, repetia e se aproveitava das coisas como quem não tinha pressa, pelo contrário, tinha todo tempo do mundo. 


\section{AGRADECIMENTOS}

A Deus, por me fazer acreditar Nele.

Ao Professor Marcos Sorrentino, por ter sido meu grande incentivador no mestrado com suas preciosas contribuições.

Ao professor Dalcio Caron, pela amizade, delicadeza e atenção prestadas em nossas discussões.

À minha banca de qualificação, em especial à Calú, pelo seu olhar crítico mas delicado, que muito contribuiu para o desfecho deste trabalho.

Ao Professor Jesus Delgado, amigo e mestre, presente desde o início desta trajetória, que apoiou e acreditou no meu trabalho e sensibilidade.

Às Professoras Neuza Nogueira e Regina Monteiro pelo carinho e confiança.

Ao IPEF, especialmente ao Edward e Viviane pelo apoio junto às empresas.

Às empresas que participaram desta pesquisa, encaminhando os materiais e colaborando com informações tão essenciais.

A CAPEs, pelo apoio que proporcionou as condições de realização deste trabalho.

Aos novos amigos e novos parceiros Andréa, Sônia, Luciano, Marcos, Ida, Rosiane, Kayo, Nelma, Pivani, Lígia, Xan, Patrícia, Paulinho e Daré, pela compreensão e apoio.

A todos os amigos que participaram de alguma forma do percurso que resultou nesta dissertação, ainda que não citados nominalmente, expresso um agradecimento especial. 
À minha família de Piracicaba, Malí, Celso, Bia, Osvaldo, Fernanda, Walter e Luna, com quem podemos contar a todo o momento.

Em especial à Zenaide, minha mãe de Piracicaba, que com orações e carinho sustentam meu coração.

Às minhas grandes amigas Sandra, Isabel, Ana Paula e Milena, presentes em momentos alegres e tristes, mas sempre presentes.

À minha grande amiga Cristina, que em poucos anos tive o privilégio de compartilhar trabalhos, alegrias, tristezas, sonhos e também a vida.

À minha tia e amiga Djanira e minha irmã de coração Mônica, que sempre estão meu lado.

Ao Eduardo, pela leitura criteriosa feita com generosidade e principalmente por sua ternura.

Aos meus pais Humberto e Dorvalina, pelo apoio afetivo e material e por me proporcionarem a oportunidade de uma nova vida.

À minha filha Lara, preciosidade em minha vida, por compartilhar todos os nossos momentos com sabedoria e alegria e com quem me sinto cada vez mais realizada. 


\section{SUMÁRIO}

Página

LISTA DE FIGURAS …......................................................... viii

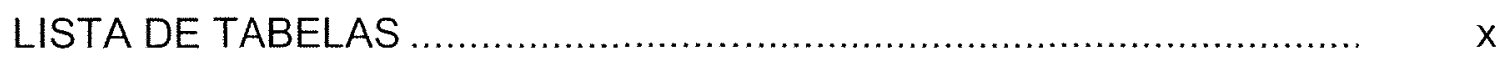

LISTA DE QUADROS ............................................................

LISTA DE SIGLAS, ABREVIATURAS E SIMBBOLOS ............................ xii

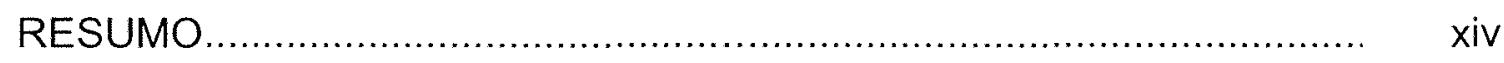

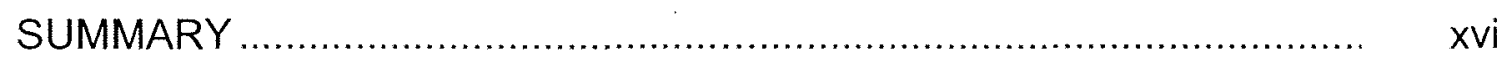

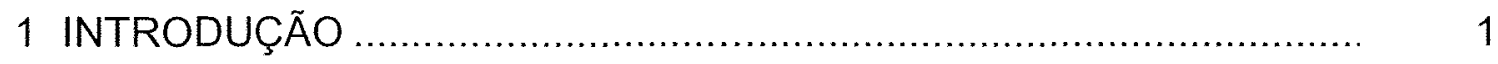

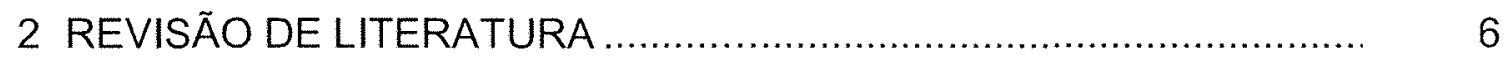

2.1 Educação ambiental ............................................................... 6

2.2 Discurso de educação ambiental nas empresas ................................ 19

2.3 Certificação e educação ambiental ................................................ 35

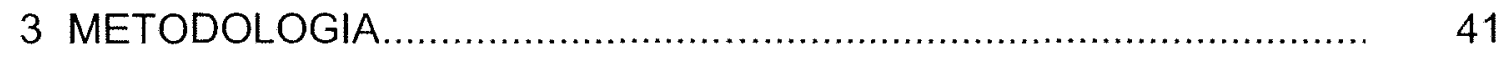

3.1 Procedimentos para obtenção de dados ....................................... 42

3.1.1 Pesquisa documental ou análise documental ............................. 42

3.1 .2 Pesquisa bibliográfica.......................................................... 43

3.1.3 Observação direta intensiva ....................................................... 44

3.1.3.1 Entrevista despadronizada ou não estruturada .......................... 45

3.1.3.2 Entrevista despadronizada ou não estruturada do tipo clínica ..... 45 
3.1.4 Observação direta extensiva ..................................................... 47

3.2 Aplicação dos questionários ...................................................... 48

3.2.1 Classificação das perguntas................................................... 50

3.3 Delimitação da pesquisa ................................................................ 53

3.4 Elaboração, análise e interpretação dos dados................................ 53

4 RESULTADOS E DISCUSSÃO ................................................. 56

4.1 Apresentação dos dados ............................................................ 56

4.1.1 Localização geográfica e análise da infra-estrutura para realização dos programas de educação ambiental.

4.1.3 Número de funcionários que trabalham no setor ambiental e formação profissional .................................................................... 63

4.1.5 Elaboração dos programas de educação ambiental .................... 67

4.1.6 Público alvo, parceiros e atividades desenvolvidas com público externo

4.1.7 Continuidade, acompanhamento e avaliação dos programas de educação ambiental 78

4.1.10 Atividades de educação ambiental com os funcionários 81

4.1.11 Certificação 85

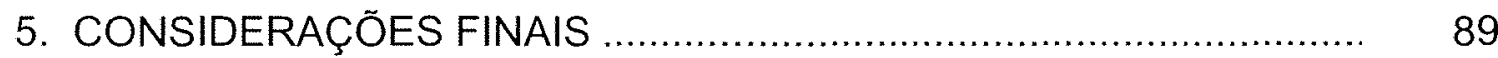

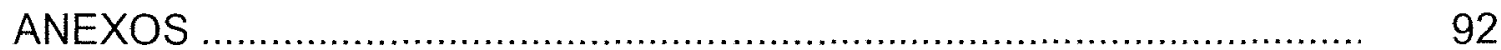

REFERÊNCIAS BIBLIOGRÁFICAS ............................................... 124 


\section{LISTA DE FIGURAS}

Página

1 Modelo de sistema de gestão ambiental para a Norma ISO14001 ..... 27

2 Localização das empresas.......................................................... 57

3 Local especialmente destinado para realização de atividades de educação ambiental.

4 Infra-estrutura do espaço reservado para atividades de educação ambiental.

5 Número de funcionários que trabalham no setor ambiental.

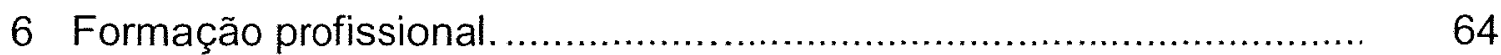

7 Elaboração dos programas de educação ambiental. .......................... 68

8 Número de programas em andamento.......................................... 69

9 Período em que o programa de educação ambiental está em

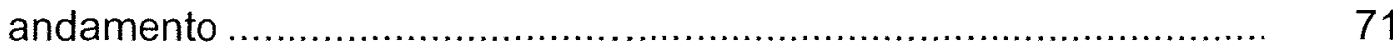

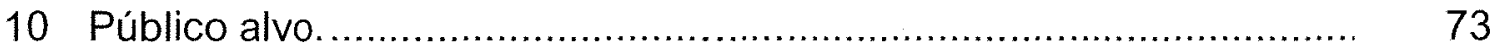

11 Temas abordados nas atividades com público externo.................... $\quad 75$

12 Média do número de participantes por ano.................................... 77

13 Acompanhamento das atividades desenvolvidas........................... 79

14 Avaliação de resultados das atividades desenvolvidas..................... 80 
15 Empresas que possuem atividades de educação ambiental com os funcionários.

16 Tipos de atividades desenvolvidas com os funcionários.

17 Temas abordados nas atividades com os funcionários.

18 Estrutura administrativa segundo o número de empresas em que os funcionários participam das atividades relacionadas à educação ambiental.

19 Certificação. 86

20 Relação do programa de educação ambiental com a certificação. 


\section{LISTA DE TABELAS}

Página

1 Localização das trilhas.

61

2 Empresas segundo número de funcionários com curso de especialização na área ambiental. 65

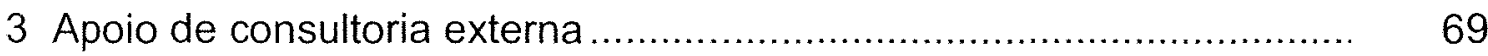

4 Elaboração de material educativo .................................................. 71

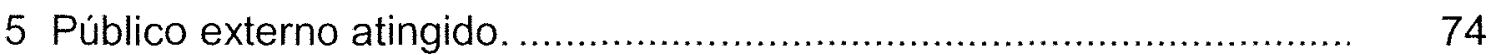

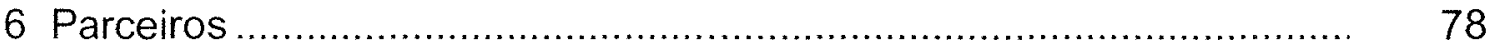

7 Continuidade dos programas de educação ambiental ........................ 78 


\section{LISTA DE QUADROS}

Página

1 Empresas pesquisadas.

2 Empresas segundo a especificação dos locais destinados aos programas de educação ambiental. .......................................................... 60

3 Empresas segundo localização, metragem e número de trilhas................ 62

4 Programas de educação ambiental desenvolvidos pela Eucatex. ...... 116 


\section{LISTA DE SIGLAS, ABREVIATURAS E SÍMBOLOS}

$\begin{array}{ll}\text { ABNT } & \text { Associação Brasileira de Normas Técnicas } \\ \text { BNDES } & \text { Banco Nacional de Desenvolvimento Econômico e Social } \\ \text { BRACELPA } & \text { Associação Brasileira de Celulose e Papel } \\ \text { BS } & \text { British Standard } \\ \text { BSI } & \text { British Standard Institution } \\ \text { CEAM } & \text { Centro de Educação Ambiental } \\ \text { CENIBRA } & \text { Celulose Nipo-Brasileira } \\ \text { CETESB } & \text { Companhia de Tecnologia de Saneamento Ambiental } \\ \text { ESALQ } & \text { Escola Superior de Agricultura Luiz de Queiroz } \\ \text { FAO } & \text { Food and Agricultural Organization } \\ \text { FBCN } & \text { Fundação Brasileira para a Conservação da Natureza } \\ \text { FSC } & \text { Forest Stewardship Council } \\ \text { GQT } & \text { Gerenciamento pela Qualidade Total } \\ \text { IBAMA } & \text { Instituto Brasileiro de Meio Ambiente } \\ \text { IKPA } & \text { Indústrias Klabin de Papel e Celulose } \\ \text { Inpacel } & \text { Indústria de Papel Arapoti } \\ \text { IPEF } & \text { Instituto de Pesquisas Florestais } \\ \text { ISO } & \text { International Standardization Organization } \\ \text { IUCN } & \text { União Internacional para a Conservação da Natureza } \\ \end{array}$


Ltda Limitada

MEC Ministério da Educação e Cultura

NBR Norma Brasileira

ONG's Organizações Não-Governamentais

ONU Organização das Nações Unidas

PACA Projeto aprendendo com a árvore

PDCA Plan, do, check, action

PGA Plano de Gestão Ambiental

PIEA Programa Internacional de Educação ambiental

PLT Project Learning Tree

PNUMA Programa das Nações Unidas para o Meio Ambiente

S.A. Sociedade Anônima

SA Social Acountability

SAGE Strategic Advisory Group on Environment

SGA Sistema de Gestão Ambiental

UIPA União Internacional de Proteção aos Animais

UNESCO United Nations Educational, Scientific and Cultural Organization

USP Universidade de São Paulo

WWF Word Wildlife Fund 


\title{
EDUCAÇÃO AMBIENTAL EM EMPRESAS DO SETOR FLORESTAL NO BRASIL
}

\author{
Autora: MÁRCIA CELESTINO MACEDO \\ Orientador: Prof. Dr. DALCIO CARON
}

\section{RESUMO}

O presente trabalho analisa os programas de educação ambiental executados por empresas do setor florestal, visando contribuir para o seu aprimoramento. A pesquisa objetivou demonstrar a relevância da educação ambiental na implementação dos Sistemas de Gestão Ambiental (SGA) e justificar porque esses programas não devem ser tratados apenas de maneira pontual. Utilizou-se 4 procedimentos para o levantamento dos dados: pesquisa documental ou análise documental, pesquisa bibliográfica, observação direta intensiva através de entrevistas e observação direta extensiva do tipo questionário. A análise dos dados coletados revela maneiras muito diversas de pensar e de atuar com a educação ambiental, entre as empresas estudadas. No detalhamento dos procedimentos adotados verifica-se que as empresas utilizam a educação ambiental sem procurar aprimorar essa prática ou tentar integrá-la aos seus procedimentos de gestão. Como conclusões e recomendações do trabalho destaca-se ser de suma importância que o 
desenvolvimento dos programas de educação ambiental objetivem uma interação do público interno (funcionários, fornecedores, etc) e público externo (população do entorno, consumidores, etc). Os profissionais que trabalham com educação ambiental devem estar conectados em profundidade com todos os elementos, estruturas e funções dos diferentes temas abordados, que incluem, necessariamente, uma preocupação com os direitos humanos. Os programas de educação ambiental devem ter a preocupação de gerar continuidade às atividades realizadas, favorecendo o surgimento de situações para reflexão e auto-conhecimento. Os processos de avaliação são essenciais na medida em que podem propiciar discussões organizadas sobre idéias e sentimentos, facilitando a compreensão dos temas estudados e favorecendo o desenvolvimento do programa. Estes programas, quando implementados pelas empresas, podem contribuir para a obtenção da certificação ambiental, e devem objetivar a compreensão do sentido dos valores sociais e a conquista de um sentimento de profundo interesse pelo meio ambiente, de forma a contribuir para a sua proteção e qualidade. Estabelecendo-se como prioridade a educação ambiental na administração das empresas, pode-se, a partir de um planejamento consciente e adequado, envolver a participação de todos em um conjunto de ações sistematizadas e integradas que, certamente, contribuirão para o efetivo sucesso do programa de educação ambiental e do próprio Sistema de Gestão Ambiental (SGA). 


\title{
ENVIRONMENTAL EDUCATION IN FOREST SECTOR COMPANIES IN BRAZIL
}

\author{
Author: MÁRCIA CELESTINO MACEDO \\ Adviser: Prof. Dr. DALCIO CARON
}

\section{SUMMARY}

This research analyzes the programs for environmental education developed by forest sector companies and intends to contribute to its improvement. The aim is to show the relevance of environmental education programs in the implementation of the Environmental Management Systems and justify why these programs shouldn't be dealt in a punctual view. Four procedures have been used to data survey: document analysis and research, bibliography research, intensive observation by interviews and extensive observation by the use of application forms. The analysis of data, among the companies that are part of this paper, reveals many different ways of thinking and acting in environmental education. The detailing of the adopted procedures, led to the conclusion that these companies make use of the environmental education without seeking the improvement of this practice or try to integrate it to their management procedures. As conclusions and 
recommendations of this paper, it is very important to emphasize that the development of environmental education programs must seek an interaction between internal users (officials, suppliers, etc.) and outer users (neighbor population, consumers, etc.). The environmental education professionals, should be deeply connected to all the elements, structures and functions of each issue, with a focus on human rights. The environmental education programs should consider the continuity of the accomplished activities, providing situations of reflection and self-knowing. The evaluation process is essential, to the extent they allow discussions about ideas and feelings, making easier the comprehension of the study issues and providing the program development. These programs, implemented by the companies, contribute to obtain the environmental certification, by the comprehension of social values sense and the conquest of a deeply interest feeling by the environment, that contributes to its protection and quality. Settling the environmental education as a priority in the business management, as of in a conscious and adequate planning, it will be possible to embrace everyone in a joint of systematic and integrated actions, that will certainly, contribute to the effective success of the environmental education programs and the Environmental Management Systems on itself. 


\section{INTRODUÇÃO}

Em junho de 2000, o Laboratório de Educação e Política Ambiental do Departamento de Ciências Florestais da Escola Superior de Agricultura Luiz de Queiroz da Universidade de São Paulo (ESALQ/USP) - Piracicaba, organizou o "Curso de Educação Ambiental para Empresas: um caminho para a prática". O evento foi monitorado por mim e pela MSc Cristina Costa Diniz, e contou com 33 participantes em sua maioria representantes de grandes empresas, tais como RIPASA, PANEX, CETESB.

Durante o curso discutiu-se temas referentes ao contexto ambiental mundial e nacional enfatizando aspectos da educação ambiental. Foram avaliadas as conseqüências ecológicas advindas do processo econômico, particularmente em sua atual fase de globalização, e as ações voltadas a diminuir e/ou evitar os seus impactos mais significativos.

Como o cuidado com o meio ambiente é, hoje, tema recorrente junto à opinião pública, particularmente nos paises mais desenvolvidos, as grandes empresas também se colocam numa perspectiva ambientalista, buscando estarem afinadas com as preferências de seus consumidores.

Dessa forma, o curso em questão discutiu o atual papel das empresas às questões relacionadas ao meio ambiente. Alguns participantes tiveram a oportunidade de relatar as atividades de educação ambiental realizadas em suas empresas, subsidiando, assim, os debates realizados em seguida.

Este trabalho é um desdobramento desse curso e tem por objetivo principal diagnosticar e discutir a importância de programas de educação ambiental nas empresas. Buscarei demonstrar a relevância em se fazer com 
que a educação ambiental permeie os Sistemas de Gestão Ambiental (SGA) e justificar porque esses programas não devem ser tratados apenas de maneira pontual.

A educação ambiental busca uma transformação profunda na humanidade e deve conter a dimensão dos direitos humanos. Ela deve acontecer no cotidiano, e porta, necessariamente uma interdependência com a natureza. É o despertar de cada um para consigo mesmo (sua própria essência), para com as outras pessoas e com o meio que as cerca.

Moggi e Burkhard (2000, p.29) quando discutem transformações pessoais e nas organizações empresariais, analisam treinamentos cujo vigor de expressão é dado aos processos do pensar. Esses processos, porém "(...) são insuficientes porque ignoram ou não dão a devida ênfase aos processos do sentir e do agir no dia-a-dia". Os autores acrescentam o fator emocional dizendo que mais do que pensar, discursar ou concordar com uma teoria, para que transformações internas realmente ocorram, é necessário sentir e também agir no mundo externo.

A mudança de paradigma intelectual requer uma expansão não apenas de nossas percepções e maneiras de pensar, como também mudanças de valores e esses valores devem ser construídos (Layrargues, 1999, p.143).

Delors (1999, p.90), explicita de forma clara o que ele denomina de "Quatro Pilares da Educação: aprender a conhecer, aprender a fazer, aprender a viver juntos e aprender a ser".

Aprender a conhecer é: “(...) adquirir os instrumentos de compreensão". É a procura incessante do conhecimento, que passa pela busca das fontes de informações, o modo pelo qual processá-las, compreendê-las e utilizá-las. É comum depararmo-nos com indivíduos que, diante de situações inesperadas, tornam-se incapazes de agir por não terem conhecimentos que possibilitem atitudes transformadoras como resposta a essas situações. Morin (2000, p.30), de forma simples sintetiza "(...), quando o 
inesperado se manifesta, é preciso ser capaz de rever nossas teorias e idéias, em vez de deixar o fato novo entrar à força na teoria incapaz de recebê-lo".

Diante disso, tão importante quanto aprender a conhecer é o aprender a fazer. Delors citado acima (1999, p.95), considera que:

"(...) a relação com a matéria e a técnica deve ser completada com a aptidão para as relações interpessoais. O desenvolvimento dos serviços exige, pois, cultivar qualidades humanas que as transformações tradicionais não transmitem, necessariamente $e$ que correspondem à capacidade de estabelecer relações estáveis e eficazes entre as pessoas".

"O educador pode possibilitar o rompimento da quietude, mas não a ação do construir, do conhecer. Essa, só o educando pode" (Madalena Freire, 1997). ${ }^{1}$ O indivíduo deve aprender a lutar, conquistar e construir seu espaço próprio. Deve aprender a ser responsável pela sua busca de conhecer, de construir sua competência. Deve aprender a pensar. Quanto a isso, podemos citar Rubem Alves (2000, p.122): "É do desenvolvimento da capacidade de pensar que se forma um povo. Povo que não pensa fica à mercê das mentiras".

Quando Delors (1999, p.96) cita o "aprender a viver juntos", é no sentido de fazer com que se estimulem e consolidem laços de cooperação e solidariedade, que conseqüentemente contribuirão para que os indivíduos adotem posturas pessoais e comportamentos sociais que lhes permitam viver numa relação construtiva consigo mesmo e com o seu meio. Como diz Madalena Freire (1997)2: "vida em grupo dá muito trabalho e prazer, porque eu não construo nada sozinho, tropeço a cada instante com os limites do outro e os meus próprios, na construção da vida, do conhecimento, da nossa história".

1 FREIRE, M. O que é grupo? Reunião Pedagógico-Educacional. Trabalho em grupo. 10/03/1997.8p. 2 idem. 
Integrando-se as três considerações anteriores sobre "aprender", estaremos "aprendendo a ser". O querer mudar, e o querer ser, são o poder da transformação.

Diante do exposto, um programa de educação ambiental tem que ser um conjunto de ações sistematizadas. Ele deve promover, simultaneamente, o desenvolvimento de conhecimento, de atitudes, ações e habilidades necessárias à conservação, recuperação e melhoria da qualidade ambiental e de vida.

Essa dissertação tem como objeto de análise os programas de educação ambiental desenvolvidos por 14 empresas do ramo de papel e celulose sediadas em alguns Estados brasileiros. Buscarei avaliar os significados atribuídos por essas empresas à educação ambiental e aos seus programas nesta área, com o propósito de contribuir para o incremento dos mesmos.

Este estudo está estruturado em quatro fases.

A primeira fase que se insere no CAPÍTULO 2 é a Revisão de Literatura, que foi subdividida em três partes. Na primeira parte, apresento um histórico da educação ambiental e a sua influência, em escala planetária, nas discussões relativas às questões ambientais. $\mathrm{Na}$ segunda parte, discuto a relação da educação ambiental com o Sistema de Gestão Ambiental (SGA) das empresas. Na terceira parte é apresentada a importância da educação ambiental nos processos de certificação das empresas, enfocando principalmente os treinamentos ministrados aos funcionários.

A segunda fase explicita a Metodologia (CAPÍTULO 3) utilizada em função dos objetivos da pesquisa, descrevendo o contexto e os procedimentos para a coleta e análise dos dados.

Na terceira fase, que envolve os Resultados e Discussão (CAPITULO 4), apresento os dados pesquisados, através de gráficos e tabelas, e faço as discussões pertinentes com base nos princípios discutidos na Revisão de Literatura. 
Finalmente, nas Considerações Finais (CAPITULO 5), demonstro a importância da educação ambiental na viabilização dos processos de gestão das empresas, através de algumas recomendações. 


\section{REVISÃO DE LITERATURA}

\subsection{Educação ambiental}

A educação ambiental visa, de maneira geral, uma transformação profunda nos valores humanos e deve ser baseada e construída no contexto de uma educação voltada à defesa dos direitos humanos, buscando-se uma sociedade mais justa em nível local, continental e planetário.

Reigota, 1995, p.11 diz:

"A educação ambiental deve procurar estabelecer uma "nova aliança" entre a humanidade e a natureza, uma "nova razão" que não seja sinônimo de auto destruição e estimular a ética nas relações econômicas, políticas e sociais."

Os países em desenvolvimento (como o nosso), são testemunho de uma qualidade de vida insatisfatória para grande parte de suas populações, devido à precariedade das condições básicas de sobrevivência - higiene, saúde, moradia, educação, alimentação e transporte, entre outras. Essa realidade assume proporções de impactos ambientais de enorme relevância, principalmente nos grandes centros urbanos.

No afã de dominar a natureza para suprir suas necessidades, o homem, em seu processo civilizatório, explorou-a através de sistemas 
econômicos que possibilitaram a produção e o consumo de bens que tornam as perspectivas de futuro insustentáveis.

Todo bem produzido e consumido gera resíduos. Até meados do século $X X$, a forma de tratar os resíduos tinha, como mentalidade dominante, deixá-los em algum lugar longe ou enterrá-los (prática ainda muito recorrente nos países do terceiro mundo). A partir dessa época, a reflexão sobre os problemas causados pela destruição das florestas, contaminação de mananciais, poluição do ar e do solo, e principalmente a produção e destinação dos resíduos, vem ganhando importantes espaços de discussão.

A prática humana de tentar dominar a natureza é anterior à chamada Revolução Industrial (iniciada em Londres, Inglaterra, no séc. XVIII) que instaurou o processo de produção de resíduos em grande escala. "É a partir do Renascimento, com seu antropocentrismo, que o homem se torna TodoPoderoso e passa a se lançar no projeto de dominação da natureza" (C.W. Gonçalves, 2000, p.27). Até então, o homem mantinha com a natureza uma relação de sacralidade que era sustentada pela fé no seu aspecto divino. $O$ sagrado desvincula-se da natureza e também das festas de colheita e fertilidade. E ainda segundo o mesmo autor, "(...) o homem descola-se da natureza e, de fora, passa a dominá-la". Na visão antropocêntrica, segundo Patrício Melo Gomes, existe a primazia do homem sobre o mundo natural, tomando-se a natureza como recurso de uso e benefício para os homens (2000, p.130)".

Em uma época muito anterior ao Renascimento, a humanidade teve que aprender a conviver numa natureza mais poderosa que ela. Aprender a relacionar-se com o ambiente era fundamentalmente uma questão de sobrevivência. Meadows (s.d) $)^{3}$ afirma que "desde o primeiro momento em que os seres humanos começaram a interagir com o mundo ao seu redor, e ensinarem seus filhos a fazerem o mesmo, estava havendo educação e educação ambiental" (citado por Czapski, 1998, p.21).

3 MEADOWS, D. Conceitos para se fazer educação ambiental. 2.ed.Nazaré Paulista: Ipê.115p. 
Houve, sem dúvida, a ruptura de uma visão da natureza como fonte de alegria, inspiração, aprendizado e também respeito, passando a predominar a concepção positivista (caracterizada pela subordinação da imaginação e da argumentação à observação de dados) e utilitarista de exploração dos recursos renováveis e não renováveis convergindo para obtenção de conforto pessoal e acumulação de bens materiais. Pode-se afirmar que a civilização ocidental é vista como uma expressão da conquista da natureza, tomada apenas como fonte de recursos.

A sociedade moderna foi constituindo-se a partir desses pressupostos de dominação da natureza e utilização crescente e irresponsável de seus recursos. Após a Segunda Guerra Mundial, principalmente a partir da década de 60 , devido à ocorrência do aumento das atividades industriais, intensificouse a percepção de que a humanidade caminhava aceleradamente para o esgotamento ou a inviabilização dos recursos indispensáveis à sua própria sobrevivência. Em várias partes do mundo, as conseqüências de um desenvolvimento desorganizado, começavam a ser sentidas. Até que alguns movimentos (os hippies, por exemplo) e iniciativas ambientalistas foram ganhando espaço, discutindo-se em última instância, a qualidade de vida e o destino da humanidade na Terra.

Em 1962, a jornalista Rachel Carson, em seu livro "Primavera Silenciosa"4, denunciava a ação destruidora do homem, em todo o mundo, degradando o ambiente. O livro provocou uma grande discussão internacional em torno das questões ambientais.

Nesse sentido, em 1968, cientistas de vários países reuniram-se em Roma formando o "Clube de Roma", onde discutiu-se o padrão de consumo, as reservas de recursos naturais não renováveis e o crescimento da população mundial. Desse encontro surgiu um dos principais documentos que chamava a atenção para os limites do planeta em suportar desgastes e o crescimento populacional (Cascino, 1999). O documento intitulado "Os Limites do 
Crescimento" alertou para a necessidade de mudanças econômicas e políticas, caso contrário, chegaríamos a um colapso.

Nesse contexto de inquietação gerada a partir dos relatórios e movimentos sociais, a Organização das Nações Unidas (ONU) realizou a Conferência das Nações Unidas sobre o Meio Ambiente Humano - a Conferência de Estocolmo, realizada entre 5 e 16 de junho de 1972. Foi a partir desse encontro, com a participação de 113 países, que se determinou o dia 5 de junho como o Dia Mundial do Meio Ambiente. Criou-se também o Programa das Nações Unidas para o Meio Ambiente (PNUMA); assinou-se um documento que tratava da importância de um trabalho de educação de jovens e adultos nas questões ambientais, com conduta responsável (dos indivíduos, das empresas e comunidades) frente à proteção e melhoramento do meio ambiente; recomendou-se a criação do Programa Internacional de Educação Ambiental (PIEA) como forma de ajudar a enfrentar a ameaça de crise ambiental no planeta (Silvia Czapski, 1998, p.29).

Em 1975, a UNESCO (United Nations Educational, Scientific and Cultural Organization) organiza em Belgrado a primeira reunião de especialistas em educação ambiental e áreas ligadas ao meio ambiente, a qual resultou na elaboração de um documento conhecido como Carta de Belgrado. Esta carta definia os objetivos, conteúdos e métodos de educação ambiental (Reigota, 1995, p.9).

Entre 14 e 26 de outubro de 1977, na ex-União Soviética, ocorreu a Conferência Intergovernamental de Educação Ambiental de Tbilisi, na qual estabeleceram-se os princípios orientadores e o caráter interdisciplinar crítico, ético e transformador da educação, que são até hoje, as referências adotadas em todo o mundo. O Brasil não teve representação oficial nesse encontro, apenas em 1997 as recomendações foram divulgadas por órgãos públicos brasileiros. 
O documento "Educação Ambiental", produzido pela Coordenação Ambiental do MEC, destacou os sete pontos principais, que traduzem o "espírito da conferência" de Tbilisi (Silvia Czapski 1998, p.31):

1. A educação ambiental é um processo permanente, dinâmico e integrativo no qual indivíduos e comunidade tomam consciência do seu meio ambiente, adquirindo valores, conhecimento, habilidades, experiências e determinação para agir individual e coletivamente para resolver os problemas ambientais;

2. a educação ambiental possibilita a aquisição de conhecimentos e habilidades capazes de induzir a mudanças de atitudes, sendo, portanto, transformadora, vindo a refletir na implantação de uma nova ordem ambientalmente sustentável;

3. a sensibilização e a conscientização do cidadão estimula a participação individual nos processos coletivos;

4. a educação ambiental vai além das atividades do ensino formal, deve estar presente em todos os grupos sociais;

5. o ambiente em seus múltiplos aspectos deve ser considerado, atuando-se com visão ampla de alcance local, regional e global;

6. a educação ambiental tem caráter permanente, pois é crescente e continuada a compreensão da complexidade dos aspectos que envolvem a questão ambiental e a evolução do senso crítico;

7. a educação ambiental deve ser contextualizadora, atuando diretamente na realidade da comunidade, sem perder de vista a dimensão planetária. 
Ainda, segundo Silvia Czapski (1998, p.34), a reunião de Tbilisi gerou quarenta e uma recomendações, cada uma delas com um conjunto de propostas. No Brasil, o Ministério da Educação e Cultura (MEC) destacou alguns dos princípios, transformando-os em "doze pequenos mandamentos". Foi, sem dúvida, um grande marco da educação ambiental.

Dez anos de Tbilisi, portanto em 1987, ocorreu a Conferência Internacional sobre Educação e Formação Ambiental em Moscou. Essa reunião, que contou com especialistas de noventa e quatro paises, reafirmou os objetivos e princípios propostos em 1977.

No Brasil, através do ensino formal nas áreas de biologia, ciências e ecologia, as questões ambientais passaram a ser levantadas e discutidas, mesmo que modestamente, a partir de meados do século $X X$. O grande encontro, realizado no Rio de Janeiro em 1992, denominado ECO-92, foi que possibilitou um melhor mapeamento das iniciativas de órgãos públicos e organizações não governamentais relacionados à educação ambiental. Constatou-se que multiplicavam-se "as iniciativas de indivíduos isolados, professores, profissionais de diversas áreas e cidadãos, sensibilizados pela questão ambiental" (Sorrentino, 2000, p.108).

Durante o encontro da ECO-92, foi finalizado e aprovado pelo Fórum Internacional de ONGs e Movimentos Sociais, o "Tratado de Educação Ambiental para Sociedades Sustentáveis e Responsabilidade Global".

O Tratado, segundo Sorrentino (1995, p.23), aponta três princípios básicos importantes:

1. "A educação ambiental deve ter como base o pensamento crítico e inovador, em qualquer tempo ou lugar, em seus modos formal, não formal e informal, a transformação e a construção da sociedade;

2. a educação ambiental é individual e coletiva. Tem o propósito de formar cidadãos com consciência local e planetária, que 
respeitem a auto-determinação dos povos e a soberania das nações;

3. a educação ambiental deve envolver uma perspectiva holística, enfocando a relação entre ser humano, a natureza e o universo de forma interdisciplinar ".

A reunião da ECO-92 teve como subsidio as conclusões apontadas no relatório Brundtland, publicado no livro "O Nosso Futuro Comum", que foi feito a partir de reuniões promovidas pelas Nações Unidas e coordenadas pela primeira ministra norueguesa Gro-Brundtland. Nesse relatório aponta-se a necessidade de realizar-se processos participativos e multidisciplinares para a elaboração de temas relacionados à educação ambiental (Cascino, 1999).

Segundo Sorrentino (2000, p.110) há quatro grandes conjuntos de temas e objetivos nos distintos projetos educação ambiental no país:

4. Biológicos: de proteger, conservar e preservar espécies, os ecossistemas, a biodiversidade, detectando as causas da degradação da natureza e estabelecendo-se bases de conservação e utilização dos recursos naturais.

5. Espirituais: de promover o autoconhecimento e também do Universo, resgatando valores, sentimentos e tradições e da reconstrução de referências espaciais e temporais que visem uma nova ética voltada em valores como verdade, amor, paz, integridade, diversidade cultural, felicidade e sabedoria, visão global e holistica.

6. Políticos: que deve desenvolver uma cultura para que os procedimentos sejam democráticos, estimulando a cidadania e a participação popular, deve estimular a formação e o 
aprimoramento de organizações, promover o diálogo na diversidade e a autogestão política; e,

7. econômicos: voltados à melhoria da qualidade de vida, gerando empregos em atividades "ambientais", não alienantes ou exploradoras do indivíduo.

Esse conjunto de temas e objetivos, deveria estar presente nas mais variadas esferas de decisão política. A hipótese de Gaia, de Lovelock em 1979 (citado por, Capra, 1996, p.90) demonstra as evidências de que o planeta é um todo indissociável, um sistema vivo, auto-organizador. Mas o que se nota, de forma geral, é que os detentores do poder político e econômico nas nações desenvolvidas e em desenvolvimento ainda demonstram timidez, ou mesmo abstenção, perante sua responsabilidade pela manutenção e melhoria das condições de sobrevivência no planeta, pela participação social nesse processo e emancipação dos cidadãos.

Boaventura de Sousa Santos, estudando a questão política na pósmodernidade, examina a questão de natureza e de ecologia.

"Quanto mais incomunicáveis forem as identidades, mais difícil será concentrar as resistências emancipatórias em projectos coerentes e globais. Ultimamente, a emergência do vínculo com a natureza e, com ele, o despertar de uma identidade ecológica transnacional parecem conferir a este vínculo um potencial globalizador promissor" (2000, p.147).

Fritjof Capra (1996, p.232), em seu livro "A Teia da Vida", destaca o princípio da interdependência entre os diferentes ecossistemas e as comunidades humanas: 
"A natureza cíclica dos processos ecológicos é um importante princípio da ecologia. Os laços de realimentação dos ecossistemas são as vias ao longo das quais os nutrientes são continuamente reciclados. As comunidades de organismos têm evoluído dessa maneira ao longo de bilhões de anos, usando e reciclando continuamente as mesmas moléculas de minerais, de água e de ar (...).Um dos principais desacordos entre a economia e a ecologia deriva do fato que a natureza é cíclica, enquanto que nossos sistemas industriais são lineares" (p.232).

Em consonância com essas idéias propostas por Capra, Carlos Walter P. Gonçalves (200.0, p.23) nos convida a uma reflexão, em seu artigo "Um pouco de filosofia no meio ambiente" quando comenta que:

"Convivemos com tal tranqüilidade com os artefatos que fazem parte da chamada tecnosfera, que sequer conseguimos imaginar um mundo em que essas coisas não estejam presentes. Dessa forma, acabamos aceitando-as como naturais ao ambiente".

E continua, comentando que temos vivido nos dois últimos séculos, após a Revolução Industrial, sob a crença de que a Ciência e a Técnica constituem formas de saber nas quais devem se apoiar os povos, a fim de assegurarem seus objetivos de "progresso" e "bem-estar". Mesmo com um acúmulo de patrimônio técnico-científico, continuamos a conviver em uma situação de miséria em grande parcela da humanidade e uma devastação da natureza sem precedentes.

Há uma cisão bastante clara entre os seres humanos e, sem falso moralismo, tem-se de um lado um enorme contingente de famintos, desabrigados, doentes sem auxilio, foragidos de guerra ou perseguição 
político-religiosa; e de outro, uma situação de conforto, sobra (ou excesso) de recursos materiais.

Ao primeiro grupo, falta-lhes condições básicas, espaços de locução para poderem participar e, a partir daí, transformarem sua própria realidade. Este é um bom indicativo de que algo está fora de consonância no planeta. No segundo grupo, o de geradores de bens materiais, serviços, etc., parece que se inicia um processo de abertura para o "diálogo" com os menos favorecidos, através de campanhas contra a fome (como a do Betinho, por exemplo), trabalhos voluntários coletivos e/ou individuais e, até mesmo, o exemplo de algumas empresas se abrindo a atendimento ao cliente ou para visitas monitoradas/guiadas.

"Existe e deve ser assegurado o direito de participação, mas ele é complementado pelo dever de participação, pois todo ser humano necessita da vida em associação, onde cada um se beneficia da solidariedade e todos têm o dever de solidariedade. Assim, pois, a participação não só é um direito, é também um dever, bastando lembrar que não se pode ter uma sociedade democrática, na qual a vontade e os interesses de todos sejam considerados, se não houver a participação" (Dallari, 2001, p.97).

Nesse sentido, passa-se a questionar cada vez mais as formas de produção industrial, poluidoras em potencial dos recursos naturais, sendo as mais perceptiveis a água, o solo e o ar.

O setor florestal (indústria de papel e celulose), objeto de análise nesse estudo, tem aproveitado o fato de possuir áreas extensas, para desenvolver programas de educação ambiental, como um benefício à comunidade. 
Pesquisas que possibilitem entendimentos sobre as várias linhas de pensamento na educação ambiental têm sido desenvolvidas por alguns autores.

Sorrentino (1995, p.14), propõe quatro grandes correntes para classificar "(...) as diversas "educações ambientais" existentes.

A primeira ele define como "Conservacionista". Esta corrente foi um dos resultados advindos das discussões internacionais que ocorreram após a publicação do livro "Primavera Silenciosa" em 1962. Atualmente ela encontrase presente em muitos paises desenvolvidos. É uma corrente direcionada a proteger amostras de toda diversidade de ecossistemas. No Brasil ela ganhou força a partir da atuação de entidades conservacionistas como UIPA (União Internacional de Proteção Ambiental) e FBCN (Federação Brasileira de Conservação da Natureza), entre outras, e também com a primeira tradução para o português de um livro sobre educação ambiental, o "Educação Ambiental" de Thomas Tanner, em $1978^{5}$.

A segunda corrente de Sorrentino é a denominada "Educação ao ar livre" que tem como premissa aguçar os sentidos e a percepção dos participantes através do contato direto e exploração dos elementos da natureza. Ela teve suas origens junto a escoteiros, espeleólogos, naturalistas e praticantes de esportes e lazer junto à natureza. Ganhou a dimensão de educação ambiental através de grupos que se auto-definem como praticantes de turismo ecológico, de percursos em trilhas de interpretação da natureza, entre outros nomes. Sorrentino também esclarece que em países do Norte, esta corrente tem um grande número de adeptos e também possui uma consciência filosófica mais apurada, com atividades ligadas à natureza e associadas a dinâmicas de grupo, que buscam "estímulo ao autoconhecimento e aprimoramento do fazer cotidiano, individual e social" (p.15).

A corrente denominada Gestão Ambiental tem como eixo principal de definição a busca da autonomia e cidadania através da participação do

${ }^{5}$ TANNER, R. T. Educação ambiental. São Paulo: EDUSP, 1978. 158p. 
indivíduo. No Brasil, essa corrente começou a destacar-se no período militar através dos movimentos contra a poluição, “(...) por liberdades democráticas [entre outros movimentos] que reivindicaram a participação da população na administração dos espaços públicos e nas definições do futuro que estávamos construindo para nós e nossos descendentes".

Conforme Sorrentino (1995, p.16), a corrente denominada "Economia Ecológica":

"(...) bebe na fonte do "ecodesenvolvimento" (Sachs, 1986) e de "O negócio é ser pequeno" (Schumacher, 1981), escritos no início dos anos 70, mas que só na segunda metade da década de 80 ganha impulso, por parte dos organismos internacionais, a partir de documentos como "Nosso Futuro Comum" (Comissão Brundtland, 1987), "Nossa Própria Agenda" (1989) e a "Estratégia Mundial para a Conservação"f"Cuidando do Planeta Terra" (IUCN IPNUMA/WWF, 1980 e 1991) e com as diretrizes de atuação dos bancos mundiais e documentos da FAO, UNESCO e outros órgãos internacionais".

A corrente Economia Ecológica é subdivida em duas vertentes. A primeira vertente, chamada de "Desenvolvimento Sustentável", aglutina empresários, governantes e uma parcela de organizações não governamentais interessadas na manutenção do "status quo".

A segunda, denominada "Sociedades Sustentáveis", é composta por aqueles que sempre estiveram na oposição ao atual modelo de desenvolvimento e que têm uma visão revolucionária, transformadora, que coloca a perspectiva da auto-gestão econômica, ou de mudanças, no próprio processo de gestão da empresa. 
Esta segunda vertente se insere nas quatro condições básicas, para se construir o desenvolvimento sustentável. São elas: "buscar uma economia factivel, ecologicamente apropriada, socialmente justa e culturalmente eqüitativa, respeitosa e sem discriminação de gênero" (Francisco Gutiérrez, 1994, citado por Gadotti, 2000, p.61).

Gadotti (2000, p.61) ainda explicita a contradição entre sustentabilidade e capitalismo: "(...) como pode existir um crescimento com equidade, um crescimento sustentável numa economia regida pelo lucro, pela acumulação ilimitada, pela exploração do trabalho, e não pelas necessidades das pessoas?".

Portanto são considerados nessa corrente, programas de educação ambiental que permitam visualizar propostas de geração de trabalho e renda e de proteção ao meio ambiente, na perspectiva de uma sociedade sustentável.

É necessário valorizar-se o interesse comum, que envolve o cuidado com o planeta, ao invés de enfatizar-se as diferenças sociais e o aumento de poder nas mãos de poucos, que visam apenas o interesse próprio.

Devemos acreditar que as pessoas são capazes e que os problemas podem ser resolvidos. A educação ambiental como educação política, requer diálogo, encontros, persistência. "Participação, engajamento, mobilização, emancipação e democratização são as palavras chave" (Layrargues, 1999, p.134). 


\subsection{Discurso de educação ambiental nas empresas}

"Os mercados de capital podem contribuir para o desenvolvimento econômico, mas podem também ser social e economicamente questionáveis por não promoverem a prosperidade de todos"6 ${ }^{2}$. Via de regra é o que se tem presenciado no setor industrial: os processos econômicos e tecnológicos ainda desprezam as questões e as necessidades sócio-ambientais.

A autora Maimon (1996, p.37-40) faz um breve histórico sobre as questões ambientais no mercado econômico. Ela salienta que até a década de 70 as empresas limitavam-se a evitar acidentes locais e a cumprir as normas de controle de poluição. O lema era: "poluía-se para depois despoluir". Havia um alto custo para a compra de tecnologias despoluidoras e ressaltava-se a crença de que havia uma incompatibilidade entre crescimento econômico e política de proteção ambiental. As empresas mantinham uma postura ambiental reativa, caracterizada pelo propósito minimo de cumprir a legislação ambiental vigente de forma a evitar problemas de fiscalização com as autoridades competentes. Buscava-se alto lucro em curto prazo, e as questões ambientais eram tratadas após os danos terem sido causados. Algumas empresas com restrições de expansão na Europa instalaram-se no Brasil atraídas pela sua abundância de recursos naturais e mão-de-obra barata, fatores que apresentavam altos custos nos países desenvolvidos.

A autora prossegue comentando sobre as crises do petróleo de 1973 e 1979 quando alguns países buscaram a diminuição do consumo energético. No Brasil tentou-se diversificar as alternativas de fontes de energia, sem, no entanto, preocuparem-se com uma possivel racionalização da utilização dos recursos energéticos ou, ainda, uma mudança de concepção quanto ao seu aproveitamento. 
Não se levou em conta a conseqüente deterioração ambiental, mas sim fatores econômicos como preços relativos dos insumos energéticos e os prováveis efeitos sobre os índices inflacionários e sobre a atividade econômica. Houve, nas décadas de 70 e 80 , um grande incremento na construção de usinas hidrelétricas, porém foram desconsiderados os impactos sociais do deslocamento de populações e os ambientais.

Maimon ainda comenta que, a pressão de movimentos ambientalistas forçou a integração do controle ambiental às práticas da economia, e este passou a ser parte integrante no desenvolvimento do processo produtivo. Um princípio básico passou a ser a prevenção da poluição com o envolvimento da economia de matérias primas e recursos energéticos e o desenvolvimento de produtos menos agressivos.

Os complexos industriais que mantiveram a competitividade ao longo da década de 80 foram o agro-industrial, químico, metal-mecânico e o de papel e celulose.

A autora enfatiza que o fator determinante dessa competitividade era o baixo custo da matéria prima resultante da disponibilidade de boas reservas de recursos naturais. Apesar da difusão da conscientização e da formulação da política ambiental, a responsabilidade ambiental era ainda incipiente. Ocorreram muitos problemas institucionais com a capacitação do corpo de fiscalização e era grande a ausência de investimentos em equipamentos e processos de prevenção à poluição.

O final da década de 80 é marcado pela ênfase dada aos pronunciamentos pelas questões ambientais. Começam os debates sobre modernidade - liberalismo econômico, qualidade total. O processo produtivo com qualidade e responsabilidade ambiental gera disputa de mercado. Ocorre a consolidação da "bioética" global, que pressupõe uma busca por valores morais e princípios ideais de conduta humana à vida. É a necessidade de sobrevivência dentro de um mercado promissor. Surge então, uma nova visão sobre o meio ambiente, onde ele passa a ser uma nova oportunidade de 
negócio, tanto tecnológico como organizacional. Surge o consumidor "verde" e, a partir daí, consolidam-se e difundem-se as inovações de tecnologias limpas e o conceito de excelência ambiental que avalia a organização não somente pelo seu desempenho produtivo, mas por seus valores éticos e pela performance ambiental.

Ainda, segundo a autora acima citada, nesse processo evidenciaramse alguns fatores determinantes da qualidade ambiental, que são: a pressão dos órgãos de controle e comunidade local; a origem do capital (nacional, multinacional, privado e público) e o grau de inserção da empresa no mercado internacional.

Essa evolução levou algumas empresas a integrar a responsabilidade ambiental na sua gestão administrativa. A questão ambiental deixa de ser uma função exclusiva da produção para tornar-se uma função da administração. Ela passa a interferir no planejamento das atividades de rotina, na discussão dos cenários alternativos e, conseqüentemente, na análise de sua evolução, gerando políticas, metas e planos de ação. Dentre as atividades/ responsabilidades da função ambiental na organização estão o treinamento e mudanças de comportamento dos funcionários e o contato com a comunidade local, governo e organizações não governamentais (ONG's).

As atividades humanas podem gerar alterações no meio ambiente. Nesse sentido, Araújo (1997, p.17) avalia que:

"(...) no contexto atual das sociedades modernas, a indústria desempenha relevante papel para o progresso econômico (....). No entanto, as atividades industriais, como a atividade humana de uma forma geral, podem constituir-se em fatores de perturbação ao meio ambiente, caso não sejam (grifo meu) conscientemente administradas". 
A produção de bens pelas empresas envolve a participação de todas as forças organizadas da sociedade.

Maimon (1996, p.19) aponta que a responsabilidade ambiental das empresas depende de sua interação com os atores internos e externos.

"(...) os principais atores externos são o governo e os respectivos órgãos de controle (local, regional e nacional), os movimentos ambientalistas, as instituições de comércio e industriais, em particular o setor de ecobusiness, as instituições de pesquisa, os sindicatos e (...) os consumidores. Dentre os internos (...) o departamento de segurança e meio ambiente, o de pesquisa e desenvolvimento, o de qualidade, o de produção, o de vendas e o de marketing, o de controle financeiro, o jurídico, o departamento de administração e pessoal, as comissões de fábrica os prestadores de serviço e terceirização".

"A educação ambiental deve ter como objetivo alcançar uma transformação profunda dos funcionários dentro da organização, do presidente ao chão-de-fábrica" (Valle, 1995, p. 11). É papel da educação ambiental a comunicação das responsabilidades em toda a empresa, e o trabalho desenvolvido deve ser realizado de forma a que todos saibam, exatamente, o que cada um deve fazer.

Valle (1995, p.11), discute a inserção da educação ambiental para discussão de novos conceitos e diz::

“(..) a incorporação dos conceitos de Desenvolvimento Sustentável e de Atuação Responsável no dia a dia de uma empresa requer mudança de cultura em todos os seus niveis funcionais. A inserção desses novos conceitos na cultura das 
empresas exige um sistema de comunicação eficiente entre seus vários níveis hierárquicos através do estabelecimento de um programa de educação ambiental que mobilize todos os seus integrantes“.

Callenbach e Capra (1993, p.107) também ressaltam que:

“(...) a mudança para tornar as operações ecologicamente responsáveis depende da participação de todas as pessoas da empresa. Qualquer membro da equipe gerencial que não esteja convencido da necessidade e das vantagens da administração com consciência ecológica precisa (...) ser motivado. Enquanto os funcionários não estiverem convencidos, o projeto malogrará, não importa quão bem tenha sido elaborado sob outros aspectos".

Maimon (1996, p.23-24) classifica 3 tipos de empresas: as responsáveis, as seguidoras e as mentirosas.

As "empresas responsáveis" têm um discurso que corresponde à ação efetiva, elas têm uma postura ético ambiental onde se considera os diferentes atores internos e externos das empresas e os respectivos interesses. Elas também contam com equipes interdisciplinares e ONG's ambientalistas. Possuem uma gestão de longo prazo, levando-se em consideração seus interesses com os da sociedade em que vivem. São empresas que visualizam a restrição ambiental como uma oportunidade de negócio.

As "empresas seguidoras" não possuem nenhum discurso ambiental, elas simplesmente obedecem às normas por questão de sobrevivência.

O que a autora denomina de "empresas mentirosas", são as que consideram bens e serviços ambientais como mercadorias. Elas utilizam-se dos direitos de poluição e recorrem a argumentos de proteção de emprego e 
da empresa nacional. Recorrem muitas vezes a "maquiagem verde", onde o discurso contradiz a ação efetiva.

Callenbach e Capra (1993, p. 100), comentam que:

“(..) uma empresa ecologicamente consciente tem uma cultura que abarca diferentes percepções, idéias, valores e comportamentos. Uma eco-auditoria bem sucedida pode identificar quais os conceitos expostos a seguir precisam de maior conscientização: estado do mundo (...); inter - relação dos problemas (..); mudança de objetos para a relações (...); mudanças das partes para o todo (...); mudança da dominação para a parceria (...); mudança de estruturas para processos (...); mudanças de auto-afirmação para integração (...); e mudança de crescimento para sustentabilidade".

Maimon (1996, p.49:52), comenta que a percepção mais comum que as empresas têm a respeito dos órgãos reguladores (municipais, estaduais ou federais) é que estes não possuem suficiente capacidade técnica e que são altamente corruptíveis. Julgam os movimentos ambientalistas como fundamentalistas e desconhecedores do setor industrial, opondo-se ao progresso. Quanto ao consumidor, ainda acreditam que existe uma preferência por mercadorias mais baratas e que não pagarão mais pelo "rótulo verde". Atualmente, nas empresas brasileiras, a responsabilidade ambiental restringese ao atendimento de normas de prevenção à poluição e aos RIMAs (relatórios de impactos ambientais). Observa-se maior responsabilidade ambiental nas empresas mais inseridas na economia internacional. Empresas exportadoras sofrem maior pressão das barreiras não tarifárias ecológicas, e os financiamentos internacionais de que necessitam são mais facilmente obtidos em razão de uma produção ambientalmente adequada. Acionistas, 
consumidores e parceiros econômicos em geral também solicitam das empresas uma forma de produção que respeite as necessidades ecológicas do planeta.

Castilho $^{7}$ (1994), citado por Bacha (1996, p.99) estudou as barreiras não tarifárias e conclui que:

"(..) as preferências ambientais dos consumidores internacionais de celulose e papel são importantes na medida em que têm se traduzido em normas restritivas às importações impostas por seus países, principalmente os da União Européia".

Atualmente, o cumprimento da legislação ambiental é uma das principais preocupações vivenciadas pelas empresas. Posicionar-se somente sob os aspectos legais é insuficiente. Enfatiza-se sobretudo sua influência no impacto das transações comerciais, nacionais e internacionais, assim como seu posicionamento perante o processo de conscientização ambiental dos consumidores.

As grandes empresas, quando se certificam, exigem que seus fornecedores e serviços terceirizados também o façam. O pequeno produtor, que é fornecedor a empresas certificadas, também terá que ter procedimentos adequados de produção, passando a integrar uma cadeia ambientalista no ciclo produtivo.

Aparentemente o que ocorre com muitas empresas são programas de educação ambiental, muitas vezes distantes do Sistema de Gestão Ambiental (SGA), que sugere um conjunto de ações sistematizadas com o objetivo de reduzir e controlar impactos ao meio ambiente. Esses programas podem

7 CASTILHO, M.R. Barreiras não Tarifárias: o caso da imposição de restrições ambientais sobre as exportaçōes brasileiras de papel e celulose. Rio de Janeiro, 1994. 106p. Dissertação (Mestrado) - Instituto de Economia Industrial, Universidade Federal do Rio de Janeiro. 
acabar tendo como única finalidade uma projeção no mercado de uma imagem de empresa ambientalmente correta, desqualificando, assim, seus objetivos principais.

Valle (1995, p.39) define Gestão Ambiental como:

"(...) como um conjunto de medidas e procedimentos bem definidos e adequadamente aplicados que visam a reduzir e controlar os impactos introduzidos por um empreendimento sobre o meio ambiente. A Gestão Ambiental requer como premissas, um comprometimento da alta direção da empresa e de seus acionistas com o estabelecimento de uma Política Ambiental clara e definida que irá nortear as atividades da organização com relação ao meio ambiente. A partir de sua Política Ambiental, expressa por diretrizes e normas internas que deverão ser de conhecimento de todos os seus empregados diretos, prestadores de serviço e colaboradores em geral, a empresa deve estabelecer seu planejamento ambiental".

A ISO-14001 é definida como:

"Norma que especifica os requisitos relativos a um sistema de gestão ambiental, permitindo a uma organização formular uma politica e objetivos que levem em conta os requisitos legais e as informações referentes aos impactos ambientais significativos" (NBR ISO 14001:1996, p.3).

Para que seja implantado um Sistema de Gestão Ambiental (SGA), de acordo com a ISO-14001 é necessário o percurso através do "Ciclo do PDCA" 
(Plan, Do, Check e Action), que é utilizado em processos de implantação do Gerenciamento pela Qualidade Total - GQT (Fiqura 1).

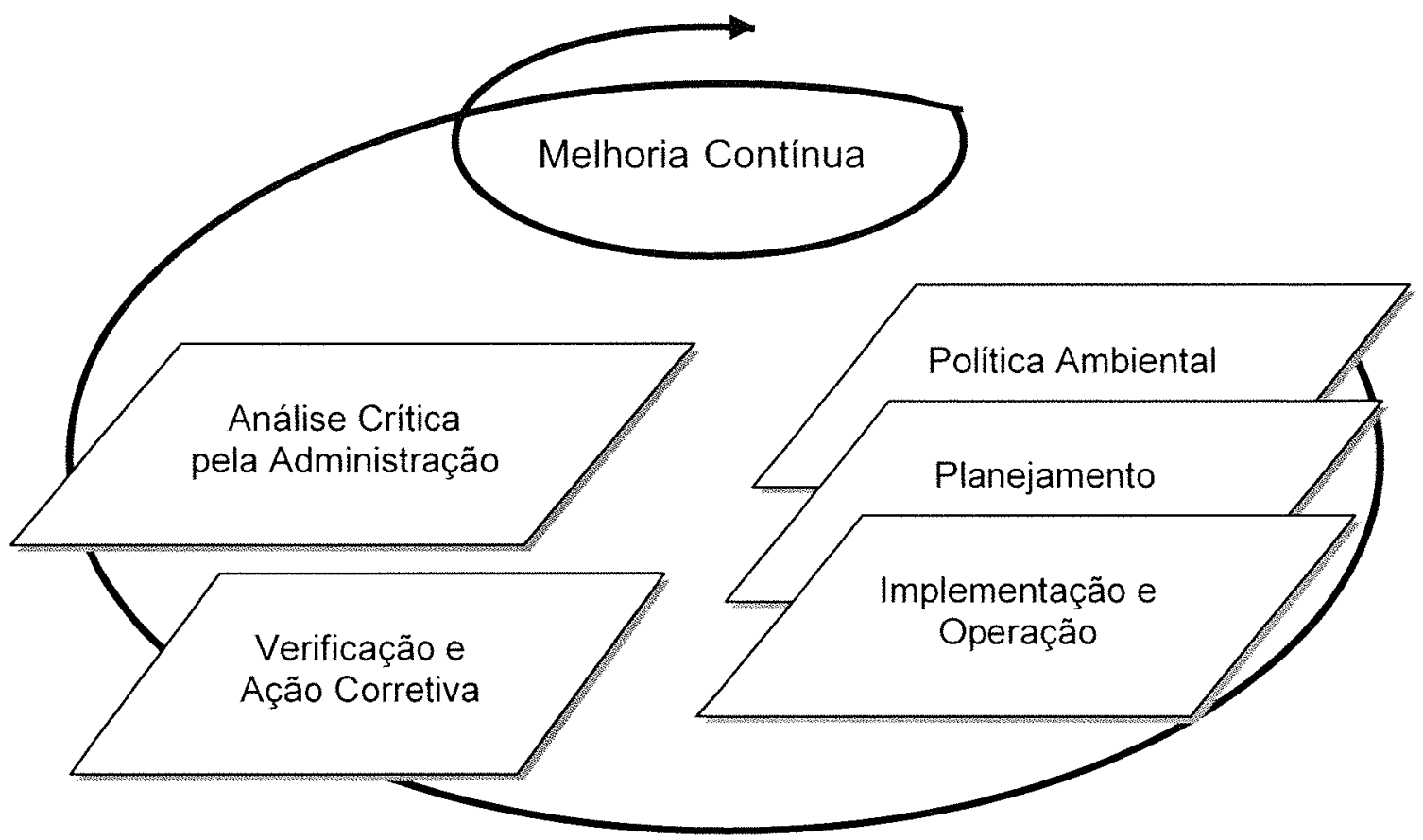

Fonte: ABNT-NBR ISO 14001:1996

Figura 1 - Modelo de sistema de gestão ambiental para a Norma ISO14001

De acordo com Abreu (2000, p.45):

"As etapas necessárias para a implantação de um Sistema de Gestão Ambiental (SGA) estão descritas a seguir:

1. Política Ambiental - na qual se define a Política Ambiental da empresa.

2. Planejamento - na qual se estabelece, a partir da identificação dos aspectos e impactos ambientais da empresa, um Plano de Gestão Ambiental (PGA). 
3. Implementação e Operação - na qual se implanta e se operacionaliza o Plano de Gestão Ambiental (PGA) definido na etapa anterior.

4. Verificação e ação corretiva - na qual se mede, monitora e avalia o desempenho ambiental da empresa, a partir do seu Plano de Gestão Ambiental (PGA).

5. Análise Crítica do Sistema de Gestão Ambiental (SGA) pela administração - na qual se avalia criticamente o Sistema de Gestão Ambiental (SGA), visando identificar novos caminhos para a empresa atingir uma melhoria contínua do seu desempenho ambiental.

A grande espiral do ciclo do PDCA (Plan, Do, Check e Action) indica que esse é sempre retomado, de forma que a melhoria contínua seja alcançada, progressivamente, a cada novo ciclo".

Braga (1995, p.221) tem uma classificação para posturas ambientais nas empresas. São elas: conservadora, legalista, estratégica e ecodesenvolvimentista.

Ela denomina "postura conservadora" a empresa que encara a questão ambiental como modismo e utiliza uma "máquina verde" para fins de marketing. "(...) a educação ambiental, quando existe é apenas um instrumento de marketing destinado a desviar a atenção dos impactos ambientais causados pela empresa".

A postura conservadora adota campanhas periódicas e os temas são questões completamente dissociadas da poluição industrial e da realidade regional. "A ênfase é biológica, abordando-se assuntos como espécies sob perigos de extinção, animais e plantas características da região. O público alvo preferencial é o externo". 
A postura legalista encara a questão ambiental como mais uma restrição do Estado e da legislação à atividade econômica. Neste caso a educação ambiental também é instrumento de marketing. $O$ público alvo preferencial é o externo e a temática biológica continua presente, no entanto inclui-se "(...) toda uma divulgação dos investimentos efetuados pela empresa em equipamentos de tratamento da poluição".

A postura denominada estratégica possui, como centralidade, uma visão estratégica da questão ambiental, da qual depende diretamente a competitividade internacional da empresa e seus produtos. Em geral as empresas que adotam essa postura:

"(...) ou assumem que poluem (...) declarando que há muito a ser feito, ou assumem que (...) já foram no passado grandes poluidoras, mas que hoje fazem de tudo o que é possivel para evitar/ reduzir a poluição. A educação ambiental (...) é um dos requisitos para a obtenção da certificação ambiental. Além de poderoso instrumento de marketing, ela passa a ser encarada como instrumento de aumento de produtividade. A ênfase em campanhas periódicas é trocada pela condução de programas mais abrangentes de periodicidade planejada"(p.222).

O público alvo preferencial é o interno, "(...) com a adoção do princípio de "treinamento da diretoria ao chão de fábrica". Quanto ao público externo (...) é realizado todo um esforço para convencer consumidores e/ou mercado internacional da adequação ambiental da empresa e do produto".

A postura Ecodesenvolvimentista discute qual é o papel da educação ambiental nas empresas e diz: 
"(...) a gestão ambiental (...) deveria ser capaz de dar conta de aspectos fundamentais atualmente negligenciados pela maioria absoluta das empresas (...), e uma educação ambiental compativel (...) deveria possuir como principais objetivos, despertar o sentimento de co-responsabilidade e facilitar o exercício da cidadania" (Braga, p.223).

Uma empresa com essa postura trabalharia tanto o público interno (os empregados ou funcionários), quanto o externo, população do entorno e consumidores. A temática seria centrada nas relações entre o sistema produtivo, a sociedade e o meio ambiente (Braga, 1995).

Obtendo-se uma visão do estado da arte dos programas pode-se mostrar que, através de um programa de educação ambiental, os Sistemas de Gestão Ambiental (SGA) poderão ser implementados com maior solidez, indo além do treinamento dos funcionários. A educação ambiental deve, portanto, permear todos os niveis do Sistema de Gestão Ambiental e não ser encarada de maneira pontual, com programas desvinculados do sistema produtivo e da realidade do entorno sócio-ambiental.

Bacha (1996, p.110), em estudo referente à criação do parque ecológico do grupo Klabin comentou que:

"(...) a criação do parque, em 1979, deve ser entendida como (aspas do autor) "fruto do aumento da consciência ecológica" dos dirigentes da Klabin ante 0 crescimento dos movimentos conservacionistas e preservacionistas. A ampliação do parque ecológico, em 1988, coincide com o período de maiores pressões internacionais contra o desmatamento nas áreas tropicais do mundo e com o maior dinamismo na criação de Unidades de Conservação no Brasil". 
Ele ainda salienta que durante as suas entrevistas pôde identificar a preocupação ambiental nos técnicos de nivel superior, faltando um trabalho de base no nível de operários rurais.

Souza (2000) em artigo publicado em site na internet, expressa o papel da educação ambiental em empresas e indústrias:

"(...) a educação ambiental é um instrumento eficaz no controle da poluição. Nesses empreendimentos, o controle da poluição deve começar no processo, estando também parte dessa responsabilidade nas mãos dos trabalhadores, pois se mantêm envolvidos diretamente na produção".

Ela ainda salienta que "as organizações estão sendo estrategicamente sensibilizadas a adotar um novo modelo de gestão empresarial contemplando a qualidade ambiental".

Nesse sentido, deve-se dar um salto qualitativo ao incorporar-se procedimentos educativos e de pesquisa que enfatizem a inserção do sujeito no seu "loco" de ação - o trabalho.

Callenbach e Capra (1993, p.107) ainda enfatizam que:

"(...) traçar e implementar os objetivos e as estratégias da empresa (...) será muito mais fácil se o estilo de administração for cooperativo e sistêmico. A atenção deve ser voltada para liberar a energia das pessoas e reconhecer o potencial latente que elas têm; dar orientação; colocar os processos em andamento; demonstrar respeito e consideração; enfatizar a intuição, o sentido, a visão; aumentar a flexibilidade; intensificar o potencial de aprendizado do sistema". 
Seguindo-se essas sugestões de compreender e realizar os empreendimentos empresariais, os autores apontam para sistemas mais integrados, onde a subjetividade ganha um espaço de interlocução.

Também Harman \& Hormann (1990, p.169) comentam que "(..) o tipo de organização em que as pessoas querem estar, compativeis com a visão holística, é aquela que dá importância ao autodesenvolvimento, à qualidade dos relacionamentos, às atividades significativas e ao esforço cooperativo".

Moggi \& Burkhard (2000, p.64) definem alguns niveis qualitativos em empresas. São eles: nivel dos recursos, que inclui tudo que é físico, material, e ocupa espaço; nível dos processos, que compreende os fluxos vitais da empresa, como matéria-prima, documentos, pessoas, dinheiro; nivel das relações, que compreende tudo o que acontece entre as pessoas (seria, segundo termo usado pelos autores, o "astral" da organização que se expressa no ambiente de trabalho); e o nível de identidade, que está relacionado à biografia da empresa, sua cultura, seus valores.

Eles ainda dizem:

"No nível da identidade, encontramos conceitos mais abrangentes. Sua compreensão exige consciência holística ou ecológica (...). Com consciência holística, compreendemos a relação do objeto com outros objetos dentro de um sistema maior. Cada nível qualitativo exige consciência e habilidade diferentes para atuar eficazmente na organização. Conforme subimos na hierarquia, mais necessária se torna à atuação segura nos níveis das relações e da identidade. Nos níveis dos recursos e dos processos, aplicamos a inteligência, o raciocínio. No nível das relações, atuamos com sensibilidade, ponderação e equilibrio emocional. No nivel da identidade, com sabedoria e intuição (...). Os processos de mudança eficazes têm como 
caracteristica a atuação com ênfase simultânea e equilibrada no limiar da ciência e da arte".

Valle (1995, p.12), diz que:

"Um programa de educação ambiental no âmbito de toda empresa deve estimular a participação de seus funcionários na apresentação de sugestões e propostas para a ação e deve permitir a reavaliação contínua dos resultados alcançados, através de campanhas de incentivo, seminários internos, eventos de congraçamento alusivos à proteção e à melhoria do meio ambiente".

Harman \& Hormann (1990, p.35) observam que:

“(...) existem amplas evidências de que as pessoas procuram basicamente atividades e relacionamentos significativos. Os seres humanos prosperam, não à base de prazeres fáceis, mas diante de desafios. Portanto, apesar de o pleno emprego não ser mais o necessário do ponto de vista da produção, a plena participação, é essencial do ponto de vista social".

Há necessidade da criação de espaços para o exercício cotidiano do diálogo e a disponibilidade de informações para que processos participativos ocorram.

Quando a participação de fato existe, ela é educativa e proporciona reflexões sobre a realidade, levando as pessoas a se sentirem capacitadas a vivenciar situações de grupo de forma mais consciente.

Gutberlet (1998, p.09) quando discute produção e consumo versus proteção ambiental enfatiza a necessidade de: 
"(..) se discutir os problemas ambientais sob uma perspectiva holística e não somente técnica, visto tratar-se de um sistema complexo; um metabolismo que apresenta infinitas interligações e interdependências, das quais algumas são de prioridade vital. Esse instrumento também pode servir na educação ambiental, uma vez que evidencia a complexidade dos fatores e das conseqüências relacionadas aos processos de produção, consumo e descarte".

A partir dessas colocações, compreende-se que as empresas têm no SGA um instrumento de prevenção e controle dos impactos ambientais que, também, visam a otimização da utilização dos recursos naturais. Nesse sentido, os programas de educação ambiental devem ser realizados dentro desse sistema de gestão, tendo como temas principais os impactos ambientais, sociais e sócio-ambientais gerados pelas indústrias.

Assuntos relacionados à fauna e flora são indiscutivelmente importantes, mas por si só não são suficientes. A educação ambiental em empresas passa a ser relevante quando coloca em pauta temas e necessidades do cotidiano. Os programas de conservação de fauna e flora devem ser incorporados ao sistema, sendo, portanto, mais um instrumento para se fazer educação ambiental e não um método.

As empresas e os seus programas ambientais devem ter como preocupação atender as necessidades do público de seu entorno, que é diretamente afetado pelos impactos que elas causam ou já causaram, visando uma boa qualidade de vida. Devem também facilitar a participação e a comunicação entre os diferentes sujeitos sociais do processo produtivo, buscando uma utilização dos recursos naturais na forma mais sustentável possivel, fazendo "uso" sem destruir ou extinguir nenhum bem, sempre pensando em conservá-lo para as futuras gerações. 


\subsection{Certificação e educação ambiental}

Até o final da década de 70 , as questões ambientais vinham sendo tratadas apenas dentro de padrões e limites estabelecidos pela legislação. A destruição progressiva do meio ambiente tornava-se muito evidente, particularmente nos paises mais industrializados por utilizarem mais largamente os recursos naturais. Isso fez com que a sociedade começasse a exigir um controle mais eficiente nas atividades que interferem na qualidade de vida, bem como uma mudança na concepção de produção e consumo, buscando racionalizar o aproveitamento dos bens naturais.

Surgiram, em alguns países, iniciativas isoladas com o intuito de identificar e de divulgar produtos que não agredissem o meio ambiente. Era o início dos chamados "selos verdes".

O primeiro surgiu na Alemanha em 1978 e foi denominado "Anjo Azul" que identificava "(...) produtos que, no julgamento de seus outorgantes não causavam os menores danos quando comparados com produtos equivalentes" (Valle, 2000, p.97). Surgiram também outros selos, entre eles o Environmental Choice no Canadá; o Green Cross e Green Seal, americanos; o Eco Mark, japonês e o White Swan dos países nórdicos. (Abreu, 2000, p.32).

Nessa época vários países criavam seus próprios selos ambientais. Em 1993, com base nas recomendações do Strategic Advisory Group on Environment (SAGE), a "International Standardization Organization" (ISO), criou um comitê técnico, o TC 207 que teve como incumbência elaborar uma série de normas internacionais sobre gestão ambiental e as ferramentas necessárias para garantir uma abordagem sistêmica que possibilitasse a certificação de empresas com o intuito de demonstrar sua eficiência no desempenho ambiental. Surge então a ISO 14000.

A "International Standardization Organization" (ISO) foi fundada em 1947 e é considerada a principal organização internacional de normalização. Sua sede fica em Genebra, na Suiça, e somente países que tenham 
organismos de normalização é que podem fazer parte da ISO. Participam 110 organismos nacionais e o Brasil que possui a ABNT (Associação Brasileira de Normas Técnicas), além de participar da ISO, também faz parte dos 18 países que compõem o Conselho Superior da ISO (Moura, 2002, p. 53 - 59).

As normas da ISO 14000 são concebidas como "(...) um sistema orientado para melhorar o desempenho ambiental da organização através da melhoria contínua de seu sistema de gestão" (Valle, 2000, p.97-98).

Em 1992 a British Standars Institution (BSI), órgão britânico de normalização, homologa a norma BS 7750 que estabelece procedimentos para a criação de um Sistema de Gestão Ambiental nas organizações.

A série ISO 9000 de Gestão da Qualidade e Garantia da Qualidade foi elaborada a partir da BS 5750 - norma britânica de Gestão de Qualidade e Garantia da Qualidade.

A versão de 1994 da norma BS 7750 (British Standard 7750, Specification for Environmental Management Systems) serviu de base para a elaboração da norma ISO 14001 - Sistemas de Gestão Ambiental Especificações e Diretrizes para Uso, cuja finalidade é equilibrar a proteção ambiental e a prevenção de poluição com as necessidades sócio-econômicas. A norma descreve os requisitos para certificação/registro e/ou autodeclaração do Sistema de Gestão Ambiental de uma organização. Ela contém pressupostos que podem, e devem, ser objetivamente auditados.

As empresas que se encontram em processo de implantação da ISO 14001 devem atender diretrizes para treinamento, conscientização e competência de seus membros, parceiros e funcionários, que dizem o seguinte:

“(..) a organização deve identificar as necessidades de treinamento e deve estabelecer e manter procedimentos que façam com que seus empregados ou membros em cada nível e função, estejam conscientes da importância da conformidade 
com a política ambiental, procedimentos e requisitos do Sistema de Gestão Ambiental (SGA); dos impactos ambientais significativos, reais ou potenciais, de suas atividades e dos benefícios do meio ambiente resultantes da melhoria do seu desempenho pessoal, de suas funções e responsabilidade em atingir a conformidade com a política ambiental, procedimentos, requisitos dos sistemas de gestão ambiental, inclusive os requisitos de preparação e atendimento a emergências, das potenciais conseqüências da inobservância de procedimentos operacionais especificados". 8

Outro exemplo de certificação é a SA 8000 , que é coordenada pela Social Accountability International, uma organização não-governamental, com sede nos Estados Unidos. Trata-se de uma Norma que funciona :

“(..) como um principio ético balizador das ações e relações da empresa com os públicos com os quais ela interage funcionários, consumidores, fornecedores e a comunidade. Seu objetivo final é a busca de valor para todos os elos da cadeia.(...) A Norma surgiu em resposta à pressão do mercado consumidor sobre empresas que ignoram o descaso de seus fornecedores em relação às condições de trabalho oferecidas em suas fábricas" (Exame, novembro 2001, p.34).

Grandes empresas buscam avaliar aspectos de responsabilidade social de seus fornecedores, que devem adequar seus processos de gestão à Norma SA 8000 , pois, caso não o façam, pode-se romper as relações comerciais existentes. A Norma é baseada nos Tratados da Organização Internacional do Trabalho, na Declaração Universal dos Direitos Humanos e na

\footnotetext{
${ }^{8}$ NBR ISO 14001, São Paulo. 1996, p.5
} 
Declaração Universal dos Direitos da Criança e segue o padrão da ISO 9000 e ISO 14000, facilitando o processo de implantação às empresas que já conhecem o sistema. Os principais pontos tratados na Norma são:

- "Trabalho infantil: é proibida a contratação de crianças de 15 anos ou menos. Se existirem funcionários nessa faixa etária, eles não poderão ser demitidos. Nesse caso, é de responsabilidade da empresa assegurar sua educação. Somados, o horário de trabalho e de permanência na escola não podem exceder, incluindo o tempo de transporte, 10 horas por dia.

- Liberdade de associação e direito à negociação coletiva: protege $o$ direito dos trabalhadores de formar sindicatos $e$ afiliar-se a grupos organizados.

- Discriminação: proíbe a discriminação baseada em cor, nacionalidade, religião, deficiência física, sexo, orientação sexual, afiliação a sindicatos ou partido político.

- Horário de trabalho: a jornada norma deverá ser de 44 horas semanais. As horas extras devem ser voluntárias e ter caráter temporário, não devendo exceder 12 horas semanais.

- Práticas disciplinares: proíbe punição física, coerção e abuso verbal no uso da disciplina. As empresas também deve impedir comportamentos, como gestos, linguagem e contato físico, que sejam sexualmente coercitivos, ameaçadores, abusivos ou exploradores.

- Comunicação: a política de responsabilidade social deve ser documentada, implementada e comunicada a todos os funcionários" (Exame, 2001, p.36). 
No que diz respeito ao setor florestal, este possui o apoio do Forest Stewardship Council (FSC). O FSC é uma entidade internacionalmente reconhecida que credencia as organizações certificadoras, de modo a garantir a autenticidade de suas declarações. O objetivo do FSC é promover um manejo florestal das florestas do mundo de forma ambientalmente adequada, socialmente benéfica e economicamente viável. Isto é feito através do estabelecimento de um padrão mundial de Princípios de Manejo Florestal (FSC, 1999). O mais antigo programa de certificação do mundo, e um dos credenciados do FSC, é o SmartWood. A rede SmartWood congrega certificadores independentes, sem fins lucrativos. As certificadoras que buscam ser credenciadas devem desenvolver padrões e guias de campo baseados nos princípios e critérios do $\mathrm{FSC}^{9}$

Seja qual for o processo de certificação, todos os funcionários devem estar envolvidos e familiarizados com o sistema.

Os cursos oferecidos sobre a Norma Ambiental devem ter uma abordagem bastante ampla que possibilite o envolvimento e o interesse na participação do processo de certificação.

Dora Abreu (2000, p.49), percebe que os cursos oferecidos nas empresas, visando uma imersão na ISO 14001, normalmente apresentam muitos detalhes técnicos com características voltadas para treinamentos. A maioria das empresas oferece pequenas palestras sobre questões ambientais, muitas vezes ministradas por funcionários que participaram de algum evento, "(...) como se alguns minutos de conversa fossem suficientes para provocar mudanças comportamentais" (Abreu, 2000, p.63).

Os programas de educação ambiental devem ser diferenciados de programas de treinamento, pois a educação ambiental possibilita a sensibilização dos indivíduos a ponto de não apenas tornarem responsáveis pelas questões ambientais da empresa, mas também por tudo aquilo que possa interferir na qualidade de vida do planeta. Ocorre o sentimento de

9 PROGRAMA DE CERTIFICAÇÂO FLORESTAL (PCF). Piracicaba: Imaflora, s.d. 2p 
pertencimento, que faz com que ele se sinta parte de uma grande teia de relações, e entenda que sua atuação pode interferir, de forma efetiva, em toda essa rede.

Cyro Valle (2000, p.13) comenta: "É fundamental que os funcionários reconheçam na educação ambiental um novo fator de progresso, não a confundindo com treinamento profissional, muito embora os dois se complementem".

Dora Abreu (2000, p.79) encerra seu livro "Sem ela nada feito!" dizendo que as empresas não podem deixar de "procurar os caminhos que levam à verdadeira educação ambiental". Dentre eles, cita:

"A verdadeira educação ambiental é capaz de resgatar os sentimentos de amor e de respeito à Terra, já que esses sentimentos ficaram perdidos no longo da caminhada humana, na ilusão de que se está na direção de uma vida mais fácil e confortável. Os benefícios da educação ambiental não se perdem quando um grupo de auditores deixa uma empresa, e é preciso que a verdadeira educação ambiental entre nas empresas, impregnando a mente das pessoas de uma consciência ecológica, requisito necessário, não só para manter a sobrevivência dessas empresas, mas, principalmente, a sobrevivência de toda a humanidade". 


\section{METODOLOGIA}

A primeira fase da pesquisa partiu de informações fornecidas por empresas cadastradas no Instituto de Pesquisas Florestais (IPEF), que através de um convênio firmado com a Universidade de São Paulo, viabiliza pesquisas ao setor empresarial florestal. Este cadastro indica os responsáveis pela área de ambiência, recursos humanos e marketing. Das 50 empresas cadastradas, 14 são associadas ao IPEF (Anexo C) e 36 não são associadas (Anexo D).

Foi encaminhado questionário a todas as empresas, tendo sido obtidas respostas de 14 empresas adiante relacionadas:

1. Aracruz Celulose S.A.

2. A.W.Faber Castel S.A.

3. Bahia Sul Celulose S.A.

4. CAF Santa Bárbara Ltda.

5. CENIBRA Celulose Nipo - Brasileira S.A.

6. Duratex S.A.

7. Eucatex S.A. Indústria e Comércio

8. IKPC - Indústrias Klabin de Papel e Celulose

9. International Paper do Brasil Ltda.

10. Inpacel - Indústria de Papel Arapoti

11. Lwarcel Celulose e Papel Ltda.

12. Rigesa Celulose, Papel e Embalagens Ltda

13. Ripasa SA Celulose e Papel

14. Veracel Celulose S.A. 
As informações solicitadas tiveram o propósito de verificar o atendimento das orientações do Sistema de Gestão Ambiental (SGA) no que tange a programas de treinamento e educação ambiental.

\subsection{Procedimentos para obtenção de dados}

Utilizou-se para obtenção dos dados 4 procedimentos: pesquisa documental ou análise documental, pesquisa bibliográfica, observação direta intensiva através de entrevistas e observação direta extensiva do tipo questionário.

\subsubsection{Pesquisa documental ou análise documental:}

A pesquisa documental é caracterizada por "(...) todos os materiais escritos que podem servir como fonte de informação para a pesquisa científica e que ainda não foram elaborados" (Lakatos e Marconi, 1982, p.56).

Todas as empresas pesquisadas tiveram seus sites consultados e 06 empresas encaminharam materiais informativos referentes aos programas de educação ambiental por elas aplicado. Esse material foi analisado e através dele buscou-se informações que pudessem complementar ou enriquecer os dados encaminhados via questionário.

Outras fontes como informes anuais, publicações de revistas e jornais também foram utilizadas como meios para complementação dos dados.

"[Os documentos] representam ainda uma fonte "natural" de informação. Não são apenas uma fonte de informação contextualizada, mas surgem num determinado contexto e fornecem informações sobre esse mesmo contexto. (...) Além disso [podem] complementar as informações obtidas por outras técnicas de coleta" (Lüdke e André, 1986, p.39). 
Holsti, 1969, citado por Lüdke e André (1986, p.3910), aponta duas situações para o uso da análise documental nas quais a presente pesquisa se enquadra:

- "Quando o acesso aos dados é problemático, seja porque o pesquisador tem limitações de tempo ou de deslocamento (...);

- Quando se pretende ratificar e validar informações obtidas por outras técnicas de coleta, como, por exemplo (...) o questionário".

Quando foram iniciadas as tarefas de investigação, criou-se um dossiê de documentos relativos à pesquisa, envolvendo pastas, cadernos, livretos, principalmente fichários.

$O$ arquivo deve conter, também, resumo de livros, recortes de periódicos, notas e outros materiais necessários à ampliação de conhecimentos, mas cuidadosamente organizados (Lakatos e Marconi, 1991, p.164).

\subsubsection{Pesquisa bibliográfica}

Para Lakatos e Marconi (1991):

"A pesquisa bibliográfica é um apanhado geral sobre os principais trabalhos já realizados, revestidos de importância, por serem capazes de fornecer dados atuais e relevantes relacionados com o tema" (p. 158)

"A pesquisa bibliográfica, ou de fontes secundárias, abrange toda literatura já tornada pública em relação ao tema em estudo, desde publicações avulsas, boletins, jornais, revistas, livros, pesquisa, monografias, teses (...), até meios de comunicação 
orais: rádio, gravações. (...) Sua finalidade é colocar o pesquisador em contato direto com tudo o que foi escrito, dito, ou filmado sobre determinado assunto. (...) A pesquisa bibliográfica não é mera repetição do que já foi dito ou escrito sobre certo assunto, mas propicia o exame de um tema sob novo enfoque ou abordagem, chegando a conclusões inovadoras" (p.183).

Buscou-se na literatura trabalhos relacionados à gestão e educação ambiental em empresas. É ainda incipiente a bibliografia referente ao tema, particularmente no que toca à educação ambiental em empresas.

\subsubsection{Observação direta intensiva}

Segundo Lakatos e Marconi (1991, p.190), há duas técnicas de observação direta intensiva: a observação e a entrevista.

A observação é uma técnica que se utiliza a partir dos sentidos em direção à "( ...) obtenção de determinados aspectos da realidade".

"A entrevista tem como objetivo principal a obtenção de informações do entrevistado, sobre determinado assunto ou problema" (Lakatos e Marconi, 1991, p.196).

"A entrevista, mais que o questionário, permite que o pesquisador se aproxime, na situação de mensuração [de] diferentes pressões sociais, pois o entrevistador pode, dentro de certos limites, variar a natureza da atmosfera, ao apresentar suas perguntas" (Selltiz, 1974, p.273). 


\subsubsection{Entrevista despadronizada ou não estruturada}

"O entrevistador tem liberdade para desenvolver cada situação em qualquer direção que considere adequada. É uma forma de poder explorar mais amplamente uma questão. Em geral, as perguntas são abertas e podem ser respondidas dentro de uma conversação informal" (Lakatos e Marconi, 1991, p.197).

Para maiores esclarecimentos das respostas advindas dos questionários, ou pelo fato de haver necessidade de uma complementação dos dados, foi efetuado contato telefônico com 6 empresas. Estes passaram a ser considerados como entrevistas, pois, era efetuado um registro dos dados levantados durante sua duração, cuja média era de 20 minutos, e acrescentadas observações e complementos assim que terminava.

\subsubsection{Entrevista despadronizada ou não estruturada do tipo clínica}

"Trata-se de estudar os motivos, os sentimentos, a conduta das pessoas. Para esse tipo de entrevista pode ser organizada uma série de perguntas especificas" (Lakatos e Marconi, 1991, p.197).

Algumas vantagens e limitações citadas pelas autoras:

Vantagens:

- "(..) Há uma maior flexibilidade, podendo o entrevistador repetir ou esclarecer perguntas, formular de maneira diferente; especificar algum significado, como garantia de estar sendo compreendido (...).

- Dá oportunidade para obtenção de dados que não se encontram em fontes documentais e que sejam relevantes e significativos. 
- Há possibilidade de conseguir informações mais precisas, podendo ser comprovadas, de imediato, as discordâncias.

Limitações:

- (...) Disposição do entrevistado em dar informações necessárias.

- (...) Ocupa muito tempo e é difícil de ser realizada" (p.197).

"Especialmente nas entrevistas não totalmente estruturadas, onde não há imposição de uma ordem rígida de questões, o entrevistado discorre sobre o tema proposto com base nas informações que ele detém e que no fundo são a verdadeira razão da entrevista. (...) A entrevista permite correções, esclarecimentos e adaptações que a tornam sobremaneira eficaz na obtenção das informações desejadas" (Lüdke e André, 1986, p.33-34).

Em três momentos utilizei a entrevista "semi-estruturada, que se desenrola a partir de um esquema básico, porém não aplicado rigidamente, permitindo que o entrevistador faça as necessárias adaptações" (Lüdke e André, 1986, p.34). O questionário foi então, aplicado pessoalmente, com duração de aproximadamente uma hora, onde houve a possibilidade de maiores esclarecimentos e detalhamentos. Tal fato deu-se devido a maioria das empresas encontrarem-se localizadas em cidades muito distantes de Piracicaba, e além disso, havia limitação de prazo para o desenvolvimento da dissertação. A proximidade geográfica com algumas destas empresas possibilitou um detalhamento maior sobre os procedimentos aplicados nos programas de educação ambiental sem, contudo, comprometer o caráter geral da pesquisa. 


\subsubsection{Observação direta extensiva}

O principal procedimento para coleta de dados foi a observação direta extensiva realizada através do questionário. A título de precaução, era efetuada uma verificação crítica preliminar tão logo os questionários retornavam, a fim de permitir em tempo hábil a identificação de informações confusas ou discrepantes (Marinho, 1980, p.34).

No entanto, antes do envio dos questionários, foi efetuado um préteste na empresa Belgo Mineira Siderúrgica de Piracicaba para verificar o formato e o conteúdo questionado. As perguntas foram respondidas pelo setor responsável pela educação ambiental e algumas alterações foram realizadas. Constatou-se que, de um modo geral, foram consideradas de fácil entendimento.

Lakatos e Marconi, 1991, p.165 comentam que, após a elaboração dos instrumentos de pesquisa, o procedimento mais utilizado para averiguação de sua validade é o teste-preliminar ou pré-teste que consiste em:

"(...) testar os instrumentos da pesquisa sobre uma pequena parte da população do "universo" ou da amostra, antes de ser aplicado definitivamente, a fim de evitar que a pesquisa chegue a um resultado falso. Seu objetivo, portanto, é verificar até que ponto esses instrumentos têm, realmente, condições de garantir resultados isentos de erros (...). A aplicação do pré-teste poderá evidenciar possíveis erros permitindo a reformulação da falha no questionário definitivo". 


\subsection{Aplicação dos questionários}

"Questionário é um instrumento de coleta de dados constituído por uma série ordenada de perguntas, que devem ser respondidas por escrito e sem a presença do entrevistador. Em geral, o pesquisador envia o questionário ao informante, pelo correio ou por um portador; depois de preenchido, o pesquisado devolve-o do mesmo modo. (...) Em média, os questionários expedidos pelo pesquisador alcançam 25\% de devolução" (Lakatos e Marconi, 1991, p.201).

Dentre as vantagens e desvantagens citadas pelas autoras, destacamos as seguintes:

Vantagens:

- "Economiza tempo, viagens e obtém grande número de dados.

- Atinge maior número de pessoas ao mesmo tempo,(...).

- Obtém respostas mais rápidas e mais precisas,(...).

- Há mais uniformidade na avaliação, em virtude da natureza impessoal do instrumento.

- Obtém respostas que materialmente seriam inacessiveis" (p.201). 
Desvantagens:

- "Percentagem pequena de questionários que volta, (...).

- Impossibilidade de ajudar o informante em questões mal compreendidas, (...).

- A devolução tardia prejudica o calendário ou sua utilização.

- O desconhecimento das circunstâncias em que foram preenchidos torna difícil o controle e a verificação" (Lakatos e Marconi, 1991, p.202).

No caso deste estudo, as perguntas foram elaboradas através da criação de categorias, que foram sendo orientadas através do quadro teórico em que se apóia a pesquisa. Foi realizado um exame do material bibliográfico, procurando-se encontrar os aspectos recorrentes. Guba e Lincoln ${ }^{11}$ (1981), citado por Lüdke e André, 1986, p.43, orientam quanto a criação de categorias e sugerem que sejam verificados "(...) temas, observações e comentários [que] aparecem e reaparecem em contextos variados, vindos de diferentes fontes e em diferentes situações. Esses aspectos (...) são a base para o primeiro agrupamento da informação em categorias".

"O processo científico não vai dos "dados" à teoria, mas parte de determinadas informações, mediatizadas por uma problemática, para uma formulação epistemológica de problemas e, em seguida, desses problemas para um corpo de hipóteses que forma a base de toda teorização" (Bruyne et al, 1977, p.102).

${ }^{11}$ GUBA, E. G.; LINCOLN, Y.S. Effective evaluation. San Francisco: Jossey-Bass, 1981. 


\subsubsection{Classificação das perguntas}

Vários autores descrevem classificações de perguntas, dentre eles Richardson (2001), Selltiz (1974) e Lakatos e Marconi (1991). Estas últimas autoras descrevem que em geral, as perguntas podem ser classificadas em 3 categorias: abertas, fechadas e de múltipla escolha.

Perguntas abertas são as que permitem ao informante responder livremente, usando linguagem própria e emitindo opiniões. Perguntas fechadas ou dicotômicas são aquelas em que o informante escolhe sua resposta entre duas opções, sim e não. $E$ as perguntas de múltipla escolha são perguntas fechadas, mas que apresentam uma série de possiveis respostas, abrangendo várias facetas do mesmo assunto (Lakatos,1991, p.206).

A técnica [perguntas de múltipla escolha] é facilmente tabulável e proporciona uma exploração em profundidade quase tão boa quanto a de perguntas abertas (Lakatos e Marconi, 1991, p.207). Foram também utilizadas perguntas onde houve a combinação de respostas de múltipla escolha com respostas abertas, possibilitando assim, mais informações sobre o assunto. Utilizou-se também no questionário perguntas do tipo mostruário, onde “(...) as respostas possíveis estão estruturadas junto à pergunta, devendo o informante assinalar uma ou várias delas" (Lakatos e Marconi 1991, p.206).

As questões foram elaboradas buscando-se respostas para o entendimento dos programas de educação ambiental propostos pelas empresas. Os trabalhos de Braga (1995) e Sorrentino (1995), serviram de apoio para construção do questionário, tendo sido, levados em conta também os autores citados na revisão bibliográfica, cujas contribuições para determinação de pontos importantes da pesquisa não poderiam ser negligenciadas.

O questionário (ANEXO B) foi preparado e enviado via e-mail ao setor responsável pela área ambiental de cada empresa e respondido pelo 
profissional encarregado do mesmo. Ele foi acompanhado por uma carta de apresentação do gerente administrativo do IPEF (ANEXO A).

\begin{tabular}{|cccccc|}
\hline & $\begin{array}{c}\text { questionários } \\
\text { respondidos }\end{array}$ & $\%$ & $\begin{array}{c}\text { questionários } \\
\text { não } \\
\text { respondidos }\end{array}$ & $\%$ & Total \\
\hline $\begin{array}{c}\text { empresas } \\
\text { associadas } \\
\text { empresas } \\
\text { não }\end{array}$ & 11 & 78.57 & 3 & 21.43 & 14 \\
$\begin{array}{c}\text { associadas } \\
\text { total }\end{array}$ & 7 & 19.44 & 29 & 80.56 & 36 \\
\hline
\end{tabular}

Quadro 1 - Empresas pesquisadas.

O Quadro 1 apresenta um resumo das empresas associadas e não associadas ao Instituto de Pesquisas Florestais (IPEF), que participaram ou não da pesquisa. Das 14 empresas associadas 11 responderam o questionário, significando $78,57 \%$. Das 36 empresas não associadas, apenas 7 enviaram o questionário respondido, o que significa $19,44 \%$ do total. São elas:

- A.W. Faber Castell S.A.

- Rigesa Celulose, Papel e Embalagens Ltda

- Veracel Celulose S.A.

- Masisa do Brasil Ltda

- Flosul Madeiras

- Trombine Florestal S.A.

- Plantar S.A.

As empresas não associadas Masisa do Brasil Ltda, Flosul Madeiras e Trombine Florestal S. A., informaram que não possuem programas de 
educação ambiental. A empresa Plantar S.A. informou que não responderia o questionário por não ter interesse em participar da pesquisa.

Dos 50 questionários enviados obteve-se retorno de 18 empresas, significando $36 \%$ do total (Quadro 1).

Quanto à representatividade dessas empresas no rol de companhias que atuam no setor florestal, foi feita uma comparação com o número de empresas associadas a Associação Brasileira de Celulose e Papel BRACELPA (ANEXO E). Das 54 empresas associadas a essa Associação, 10 foram estudadas no presente trabalho, significando $18,51 \%$ (dados coletados em junho de 2001).

As empresas Aracruz, Bahia Sul, Cenibra, Inpacel, International Paper, Klabin, Lwarcel, Rigesa, Ripasa e Veracel, pertencem ao grupo de empresas produtoras de papel e celulose. Já as empresas: Duratex, Eucatex, A.W. Faber Castell e CAF Santa Bárbara, pertencem ao grupo de produção de madeira para outros fins (móveis, aglomerados, lápis, etc.). Muitas vezes essas empresas fornecem madeira para as que são produtoras de papel e celulose, porém, este não é seu produto principal.

Os programas de educação ambiental, propostos pelas empresas, estão relacionados no ANEXO F de maneira sucinta.

Todas as informações que foram obtidas no processo da pesquisa, envolvendo questionários, entrevistas, coleta de dados através de sites específicos e materiais fornecidos pelas empresas, encontram-se em arquivo particular da mestranda, e está disponivel para consulta.

Devido ao grande número de empresas pesquisadas não foi possível checar pessoalmente todas as informações, porém os dados são relevantes à medida que possibilitam a verificação do quadro conceitual atribuído por cada empresa ao seu programa de educação ambiental. 


\subsection{Delimitação da pesquisa}

"Delimitar a pesquisa é estabelecer limites para a investigação. A pesquisa pode ser delimitada em relação:

- ao assunto: selecionado um tópico, a fim de impedir que se torne ou muito extenso ou muito complexo;

- à extensão - porque nem sempre se pode abranger todo o âmbito onde o fato se desenrola;

- a uma série de fatores - meios humanos, econômicos e de exiqüidade de prazo - que podem restringir o seu campo de ação" (Lakatos e Marconi, 1991, p.162).

A presente pesquisa limitou-se à verificação de algumas características dos programas de educação ambiental, considerando-se principalmente o trabalho de Braga, 1995, quando a autora estabelece posturas de educação ambiental (ver página 28), sem, no entanto aprofundarse nas práticas e conteúdos das mesmas.

\subsection{Elaboração, análise e interpretação dos dados}

"Após a coleta dos dados, eles são elaborados e classificados de forma sistemática. Antes da análise e interpretação, os dados devem seguir os seguintes passos: seleção, codificação e tabulação.

- Seleção: é o exame minucioso dos dados. De posse do material coletado, o pesquisador deve submetê-lo a uma verificação crítica, a fim de detectar falhas ou erros, evitando informações confusas, distorcidas, incompletas, que podem 
prejudicar o resultado da pesquisa (...). A seleção concorre também para evitar posteriores problemas de codificação.

- Codificação: é a técnica operacional utilizada para categorizar os dados que se relacionam. Mediante a codificação, os dados são transformados em símbolos, podendo ser tabelados e contados. A codificação divide-se em duas partes: 1. classificação dos dados, agrupando-os sob determinadas categorias; 2. atribuição de um código, número ou letra, tendo cada um deles um significado. Codificar quer dizer transformar o que é qualitativo em quantitativo, para facilitar não só a tabulação dos dados, mas também sua comunicação.

- Tabulação: é a disposição dos dados em tabelas, possibilitando maior facilidade na verificação das inter-relações entre eles. É uma parte do processo técnico de análise estatística, que permite sintetizar os dados de observação, conseguidos pelas diferentes categorias e representa-las graficamente. Dessa forma, poderão ser melhor compreendidos e interpretados mais rapidamente" (Lakatos e Marconi, 1991, p.166-167).

Seguidas as orientações para elaboração dos dados, feitas pelas autoras Lakatos e Marconi, procedeu-se a análise e interpretação dos dados, a fim de obter-se respostas às sobre os programas de educação ambiental. Prosseguiu-se com a interpretação dos dados, que se refere ao "verdadeiro significado do material apresentado, em relação aos objetivos propostos e ao tema" (Lakatos e Marconi, 1991, p.168), utilizando-se sempre dos conhecimentos teóricos para obtenção dos resultados.

Para visualização dos resultados obtidos, ficou estabelecida a apresentação de tabelas, gráficos e quadros que têm o propósito de : 
"(...) auxiliar na apresentação dos dados, uma vez que facilita, ao leitor, a compreensão e interpretação rápida da massa de dados, podendo, apenas com uma olhada, apreender importantes detalhes e relações. Todavia seu propósito mais importante é ajudar o investigador na distinção de diferenças, semelhanças e relações, por meio da clareza e destaque que a distribuição lógica e a apresentação gráfica oferecem às classificações" (Lakatos e Marconi, 1991, p.169).

O tratamento dos resultados foi feito através do cálculo das percentagens porque:

"Geralmente, a análise de conteúdo visa a um tratamento quantitativo que não exclui a interpretação qualitativa. (...) O mais simples consiste no cálculo de freqüências e percentagens que permitem estabelecer a importância dos elementos analisados" (Richardson, 1999, p.233). 


\section{RESULTADOS E DISCUSSÃO}

\subsection{Apresentação dos dados}

Os dados apresentados a seguir referem-se a tabulação das informações fornecidas pelas empresas que responderam ao questionário. As perguntas efetuadas nos questionários foram transformadas em 7 categorias, são elas:

1. Localização geográfica e análise da infra-estrutura para realização dos programas de educação ambiental;

2. número de funcionários que trabalham no setor e formação profissional;

3. elaboração dos programas de educação ambiental;

4. público alvo, temas abordados com público externo e parceiros;

5. continuidade, acompanhamento e avaliação dos programas de educação ambiental;

6. atividades de educação ambiental desenvolvidas com os funcionários;

7. certificação.

Essas categorias são analisadas num paralelo com o referencial bibliográfico, onde também apresenta-se sugestões e/ou comentários a respeito de cada uma delas. 


\subsubsection{Localização geográfica e análise da infra-estrutura para realização dos programas de educação ambiental.}

A Figura 2 representa a localização das empresas analisadas segundo distribuição nos Estados. Das 14 empresas, 42,86\% estão localizadas no interior do Estado de São Paulo. Na análise por região, 64,29 \% localizam-se na região sudeste, $21,43 \%$ região sul e $14,29 \%$ região nordeste.

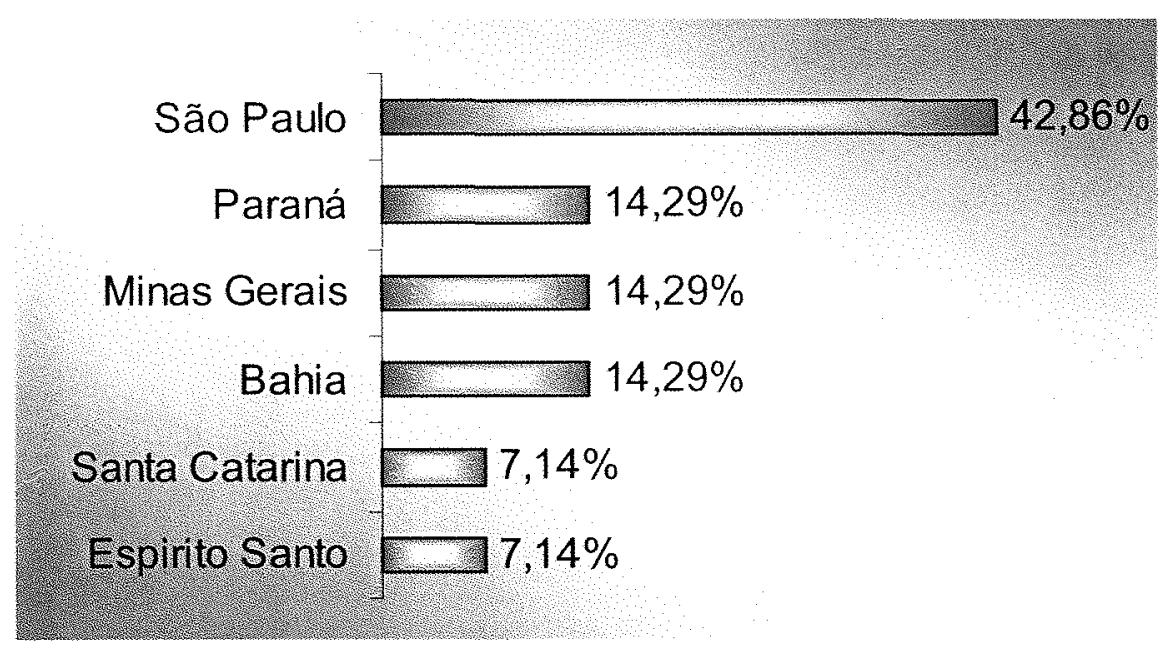

Figura 2 - Localização das empresas.

Constata-se também que todas as empresas possuem um setor especialmente destinado às questões ambientais. Algumas empresas informaram os setores aos quais a área ambiental está vinculada. São eles: gerência de meio ambiente corporativo, gerência ambiental - área fabril ou divisão de madeira. Não efetivou-se estudo específico dos organogramas das empresas, porém, através do questionamento referente a infra-estrutura destinada aos programas de educação ambiental, pode-se constatar que cerca de $93 \%$ das empresas analisadas, ou seja, 12, possuem um local especialmente destinado à realização de atividades de educação ambiental, conforme exposto na Figura 3. 


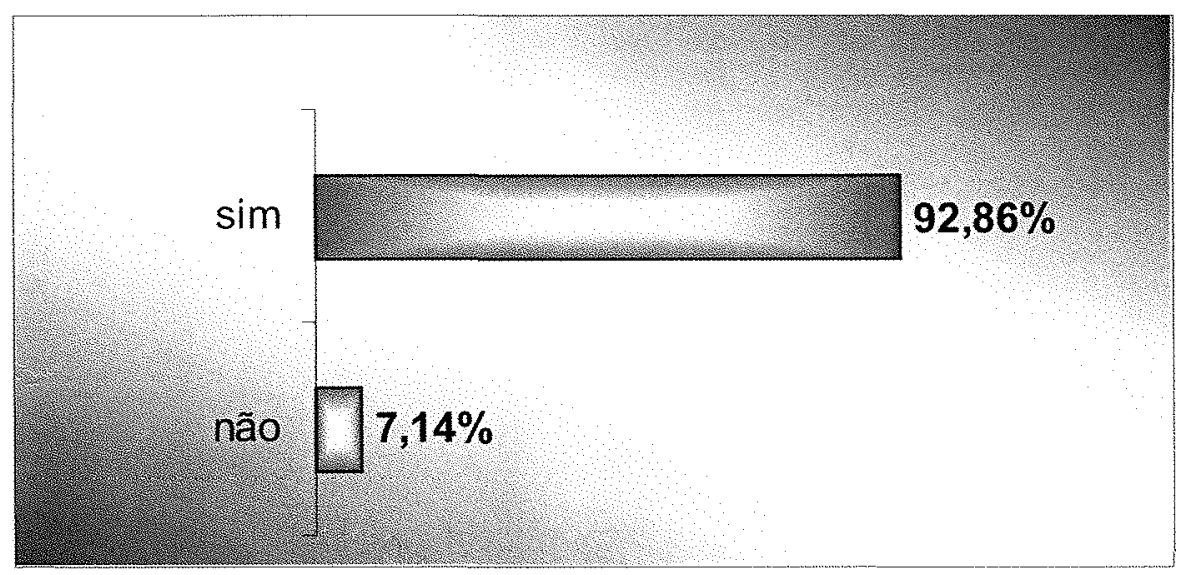

Figura 3 - Local especialmente destinado para realização de atividades de educação ambiental.

Das 12 empresas que possuem espaços destinados às atividades de educação ambiental, 3 não responderam às perguntas sobre infra-estrutura. Das 9 empresas restantes, 7 possuem centros de educação ambiental, uma possui local destinado a atividades externas e uma possui local reservado para cursos e treinamentos. Dessas empresas, $56 \%$ possuem algum tipo de museu, normalmente com temas relacionados à fauna e flora, $67 \%$ possuem animais em cativeiro, $78 \%$ possuem auditório, $44 \%$ sala de aula e $33 \%$ biblioteca. A maioria tem disponibilidade para áreas de alimentação e a totalidade possui instalações sanitárias (Figura 4). 


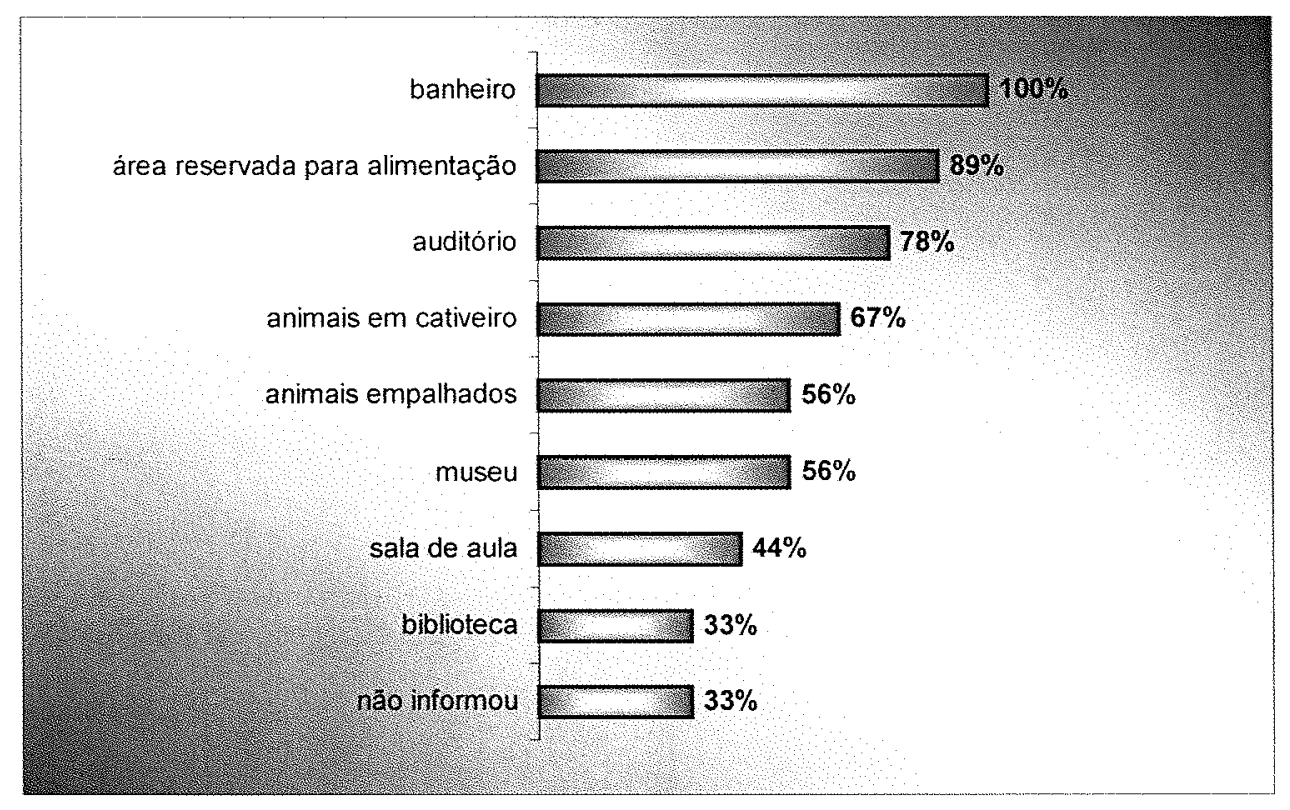

Figura 4 - Infra-estrutura do espaço reservado para atividades de educação ambiental.

$O$ item infra-estrutura é relevante à medida em que possibilita visualizar os investimentos feitos pelas empresas.

Centros de educação ambiental que disponibilizam materiais educativos e propostas pedagógicas com aprofundamento teórico, com certeza contribuem significativamente para alcançar os objetivos propostos pela educação ambiental.

O Quadro 2 descreve os tipos de instalações utilizadas pelas empresas nas atividades de educação ambiental.

Observa-se que, $42,86 \%$ das empresas não possuem área reservada para atividades externas.

Verifica-se que $50 \%$ das empresas, ou seja, 7, possuem sala especialmente destinada a cursos e treinamentos. Destas empresas, $85,71 \%$, ou seja, 5 (hachurado no Quadro 2), possuem um centro de educação ambiental. 


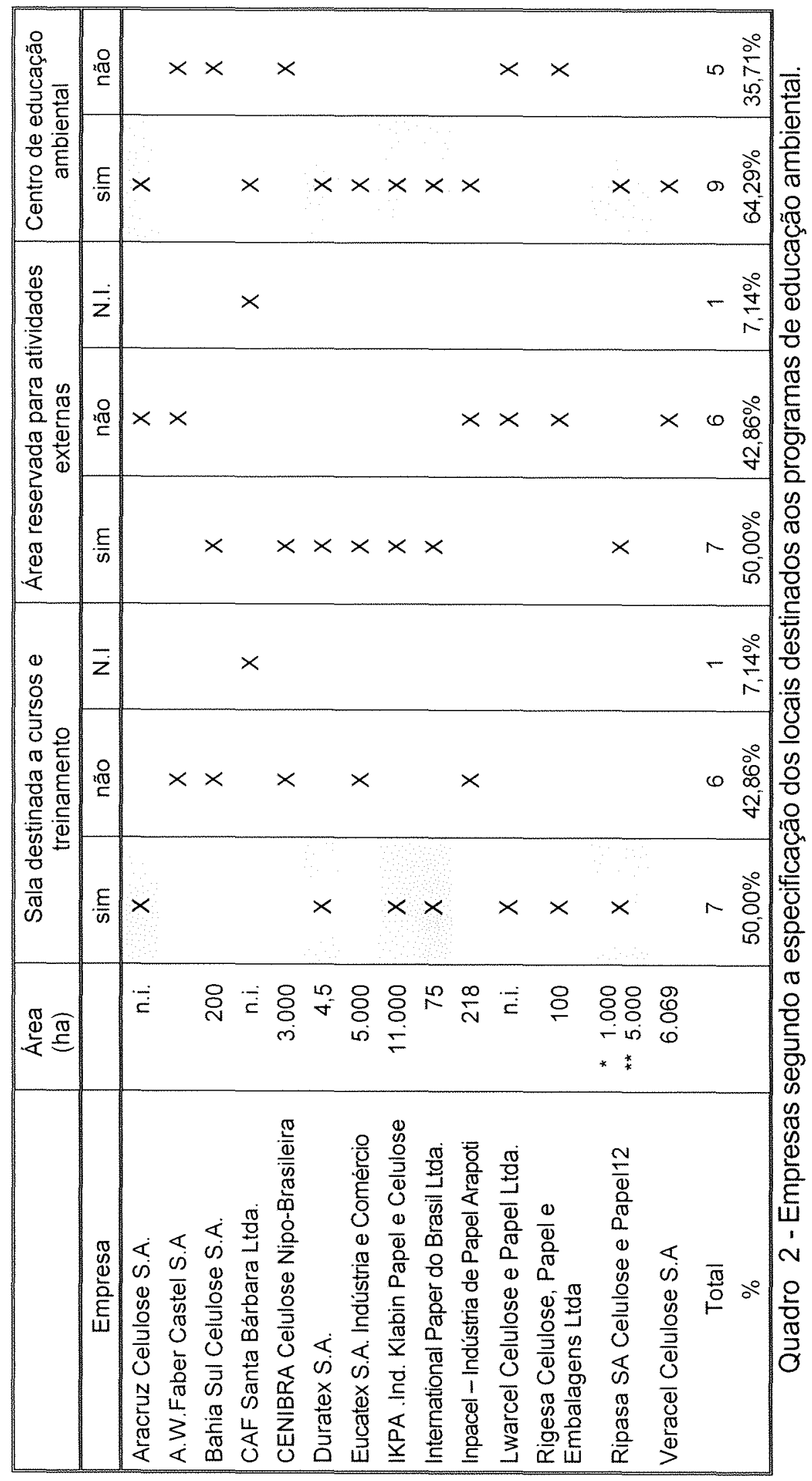


As empresas que possuem centro de educação ambiental somam $64,29 \%$. Estes centros localizam-se em região onde há produção de floresta.

As áreas destinadas a produção de floresta, incluem a manutenção de uma reserva natural. Estes espaços são adequados para implantação de trilhas interpretativas. Os centros de educação ambiental são construídos próximos a estas áreas com a finalidade de promover as atividades de educação ambiental.

O Quadro 3 apresenta a localização, as metragens e o número de trilhas que cada empresa possui.

Constata-se a utilização de trilhas interpretativas em 11 empresas, totalizando $78,57 \%$. Verificamos que, dessas empresas, 2 possuem, cada uma, mais que 5 trilhas, conforme demonstrado no Quadro 3.

Nota-se também que, das 11 empresas que possuem trilhas, $81,82 \%$ as têm próximas às suas instalações fabris (Tabela 1).

Tabela1. Localização das trilhas.

\begin{tabular}{|c|c|c|}
\hline & n. ${ }^{\circ}$ de empresas & $\%$ \\
\hline na própria empresa & 9 & 81,82 \\
\hline outro local & 2 & 18,18 \\
\hline Total & 11 & 100,00 \\
\hline
\end{tabular}




\begin{tabular}{|c|c|c|c|c|}
\hline \multirow[b]{2}{*}{ Empresa } & \multirow[b]{2}{*}{ não } & \multicolumn{3}{|c|}{$\operatorname{sim}$} \\
\hline & & $\begin{array}{l}\text { na própria } \\
\text { empresa }\end{array}$ & quantas & $\begin{array}{c}\text { Metragem } \\
\text { m (lineares) }\end{array}$ \\
\hline Aracruz Celulose S.A. & $x$ & & 0 & \\
\hline A.W.Faber Castell S.A. & $x$ & & 0 & \\
\hline Bahia Sul Celulose S.A.* & & $x$ & 2 & total 3000 \\
\hline CAF Santa Bárbara Ltda* & & $x$ & 1 & n.i. \\
\hline $\begin{array}{l}\text { CENIBRA Celulose Nipo - } \\
\text { Brasileira S.A. * }\end{array}$ & & $x$ & 1 & 1.000 \\
\hline Duratex S.A. * & & $x$ & 1 & 1.000 \\
\hline $\begin{array}{l}\text { Eucatex S.A. Indústria e } \\
\text { Comércio* }\end{array}$ & & $x$ & 2 & $\begin{array}{l}1.200 / \\
2.100\end{array}$ \\
\hline $\begin{array}{l}\text { IKPA - Indústrias Klabin de } \\
\text { Papel e Celulose.* }\end{array}$ & & $x$ & 1 & 3.000 \\
\hline $\begin{array}{l}\text { International Paper do Brasil } \\
\text { Ltda. }^{*}\end{array}$ & & $x$ & 6 & variadas \\
\hline $\begin{array}{l}\text { Inpacel - Indústria de Papel } \\
\text { Arapoti* }^{\star}\end{array}$ & & $x$ & 1 & 2.500 \\
\hline $\begin{array}{l}\text { Lwarcel Celulose e Papel } \\
\text { Ltda. }\end{array}$ & $x$ & & 0 & \\
\hline $\begin{array}{l}\text { Rigesa Celulose, Papel e } \\
\text { Embalagens Ltda* }\end{array}$ & & $x$ & 1 & n.i. \\
\hline Ripasa SA Celulose e Papel & & outro local & 2 & $1.600 / 1.000$ \\
\hline Veracel Celulose S.A. & & outro local & 5 & variadas \\
\hline Total & 3 & 11 & & \\
\hline$\%$ & $21,43 \%$ & $78,57 \%$ & & \\
\hline
\end{tabular}

Quadro 3 - Empresas segundo localização, metragem e número de trilhas.

Este trabalho não efetuou um acompanhamento das práticas de educação ambiental nas trilhas interpretativas, o que poderia ter sido de grande importância para uma análise mais aprofundada dos conteúdos abordados.

* Empresa instalada junto à produção de floresta. 
Porém é importante citar que:

"Um dos objetivos das trilhas de uso público em áreas naturais é suprir as necessidades recreacionais de maneira a manter o ambiente estável e permitir ao visitante a devida segurança e conforto" (Rocha, 1997, p.20).

É recomendável que as trilhas de interpretação da natureza sejam utilizadas com muita cautela, pois sua importância vai além de uma simples caminhada. Há trilhas que disponibilizam informações de conceitos biológicos, as que propiciam momentos de admiração da natureza ou reflexões sobre o próprio indivíduo, entre outras possibilidades. Portanto, faz-se necessário um estudo criterioso de quais objetivos pretende-se alcançar com a criação das trilhas.

"Ao caminhar pelos espaços naturais, somos convidados não mais a observar o que vemos, mas observar a nós mesmos enquanto componentes daquele ambiente" (Mendonça, 2000, p.138).

\subsubsection{Número de funcionários que trabalham no setor ambiental e formação profissional}

Observa-se que $42,86 \%$ das empresas possuem de 4 a 6 pessoas trabalhando diretamente nos programas de educação ambiental e 28,57\% possuem 7 funcionários ou mais, conforme demonstrado na Figura 5. 


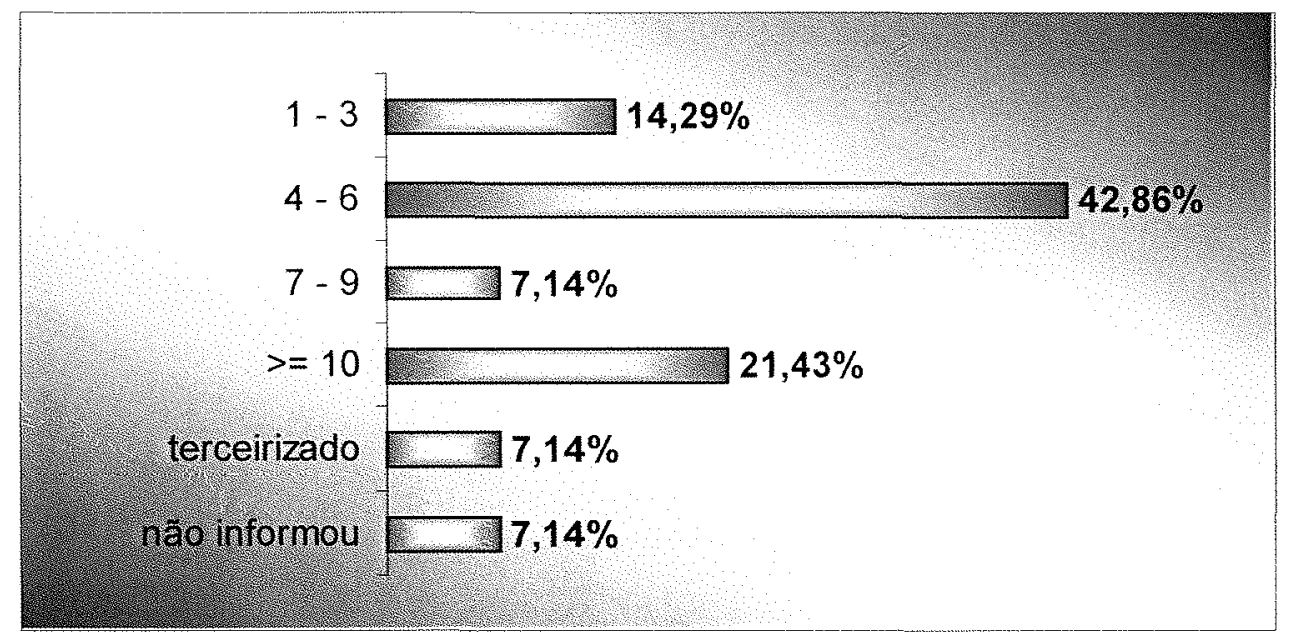

Figura 5 - Número de funcionários que trabalham no setor ambiental.

Analisando a formação profissional dos funcionários que trabalham nos programas de educação ambiental (Figura 6), observa-se que 1,45\% possuem apenas o $1^{\circ}$ ou $2^{\circ}$ grau, $12,32 \%$ são profissionais da área ambiental (biólogo, ecólogo, engenheiro agrônomo ou florestal, técnico agrícola, em pecuária ou florestal), 17,39\% dos profissionais não são formados para a área ambiental e $68,84 \%$ do pessoal operacional citado não tiveram a formação profissional especificada pela empresa. A maioria das empresas só especificou a formação do coordenador do programa.

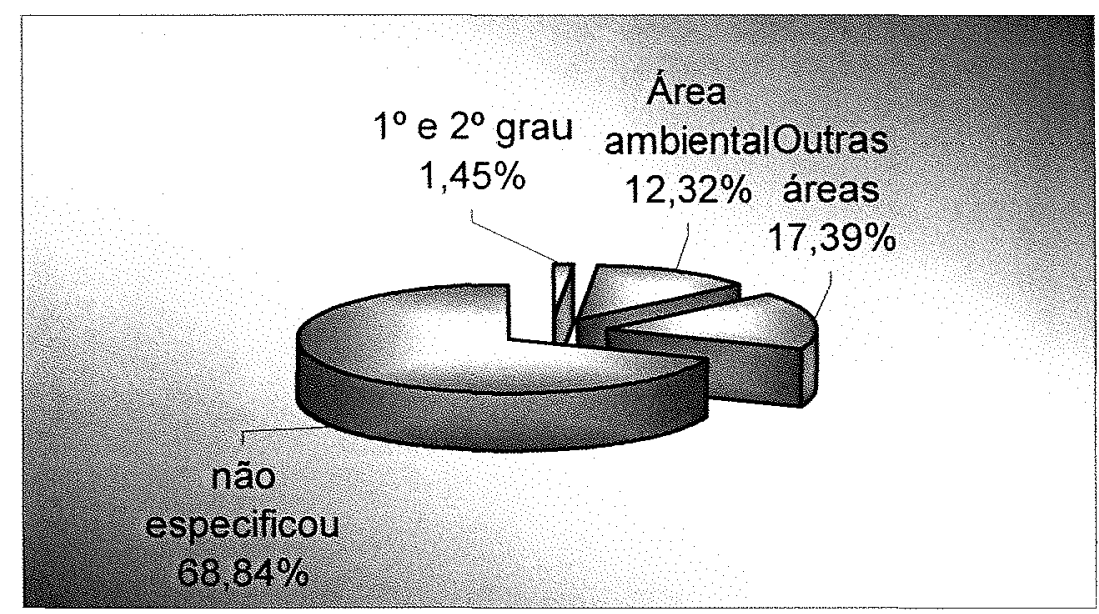

Figura 6 - Formação profissional. 
A Tabela 2 apresenta dados referentes ao número de empresas que possuem profissionais com curso de especialização na área ambiental atuando nos programas de educação ambiental. O questionamento refere-se a cursos de especialização, mestrado ou doutorado.

Tabela 2. Empresas segundo número de funcionários com curso de especialização na área ambiental.

\begin{tabular}{lccc}
\hline & \multicolumn{3}{c}{$\mathrm{n}^{\circ}$ de funcionários } \\
Empresa & nenhum & um & dois \\
\hline Aracruz Celulose S.A. & & $X$ & \\
A.W.Faber Castell S.A. & & & $X$ \\
Bahia Sul Celulose S.A. & & $X$ & \\
CAF Santa Bárbara Ltda. & & $X$ & \\
CENIBRA Celulose Nipo - Brasileira S.A. & $X$ & & \\
Duratex S.A. & & $X$ & \\
Eucatex S.A. Indústria e Comércio & $X$ & & \\
IKPA - Indústrias Klabin de Papel e Celulose & $X$ & & \\
International Paper do Brasil Ltda. & $X$ & & \\
Inpacel - Indústria de Papel Arapoti & $X$ & & \\
Lwarcel Celulose e Papel Ltda. & $X$ & & \\
Rigesa Celulose, Papel e Embalagens Ltda & $X$ & & \\
Ripasa SA Celulose e Papel & $X$ & & \\
Veracel Celulose S.A. & & $X$ & \\
$\quad$ Total & & & \\
$\quad \%$ & 57,14 & 35,71 & 7,14 \\
\hline
\end{tabular}

Conforme demonstrado na Tabela 2, verifica-se que $57,14 \%$ das empresas não possuem profissionais com curso de especialização na área de educação ambiental (especialização, mestrado ou doutorado). 35,71\% possuem alguma formação específica na área ambiental, e a empresa que 
possui 2 especialistas é a que terceiriza os serviços dos programas, sendo, portanto, funcionários da empresas de consultoria.

No entanto, faz-se necessário enfatizar que:

“(..) para um programa de educação ambiental atingir seus objetivos ele deve ser elaborado por profissionais que estejam familiarizados com técnicas utilizadas na resolução de problemas, fazendo com que os alunos ou participantes melhorem sua capacidade de observação, reconheçam e analisem os fatos, formulem hipóteses, deduções, previsões, etc" (Hungerford, 1992, p.XII) - traduzido do espanhol.

Os profissionais que trabalham com educação ambiental devem estar conectados em profundidade com todos os elementos, estruturas e funções dos diferentes temas ambientais estudados, incluindo também a preocupação com relação aos direitos humanos, a educação para a cidadania e a promoção da saúde.

"Devem ajudar os alunos a atingirem conhecimentos sobre o meio ambiente, e, sobretudo fazer com que adquiram capacidade para trabalhar individual e coletivamente com a finalidade de conseguir manter um equilíbrio dinâmico entre qualidade de vida e qualidade do entorno" (Propósito geral da educação ambiental, Hungerford, 1992, p.XI) - tradução do espanhol. 
Ainda, segundo Cascino, 1999, p.94,

"(..) professores que saltam da condição de contratados para "treinar", para a condição de parceiros que munidos de uma sistematização competente, assumem a cumplicidade de contribuir com a temporalidade - os ritmos preexistentes no ambiente local, reconstruindo os campos relacionais, recriando percepções e perspectivas."

Essa condição citada por Cascino, também pode referir-se a outros profissionais atuantes na área, ou seja, profissionais de diferentes áreas podem assumir o papel de parceiros desde que tenham capacidade de percepção dos ritmos preexistentes no ambiente. Estes profissionais devem possuir uma formação teórica que favoreça a compreensão dos alunos, e sua atuação com relação aos problemas ambientais. Dai a necessidade de aprofundamento nos conceitos e práticas de educação ambiental.

\subsubsection{Elaboração dos programas de educação ambiental}

"Um programa de educação ambiental pode ser definido como um conjunto de atividades propostas (...) relacionadas com os conhecimentos, competências, atitudes e comportamentos para adotar um modo de vida em harmonia com o entorno. Esta definição implica algo mais que a simples preparação dos documentos na escola ou no sistema educativo nacional. Significa, de fato, que as instâncias envolvidas deverão encarregar-se de desenhar programas que facilitem a aquisição destes conhecimentos, permitam dominar as técnicas de resolução de problemas, possibilitem a evolução das crenças e valores e a aprendizagem teórica e prática do exercício de ação da cidadania. Como se vê, o processo de preparação dos 
programas não se limitam tão somente a elaboração do material pedagógico, já que nele intervêm outros fatores, como a elaboração de objetivos e metas, o conteúdo de ensino para alcançar estes objetivos e metas, a estruturação deste conteúdo, os métodos pedagógicos e por último a avaliação da eficácia do conteúdo e dos métodos com relação ao alcance destas metas e objetivos" (Hungerford, 1992, p.11) - traduzido do espanhol.

A grande maioria das empresas, ou seja, 12 empresas $(85,71 \%)$, elaborou seus próprios programas de educação ambiental. Apenas $7,14 \%$, que corresponde a uma única empresa, contrata serviços de consultoria externa para elaboração do projeto e uma outra, também correspondendo a $7,14 \%$ do total, tem seu programa baseado em um modelo americano. Esses dados estão representados na Figura 7.

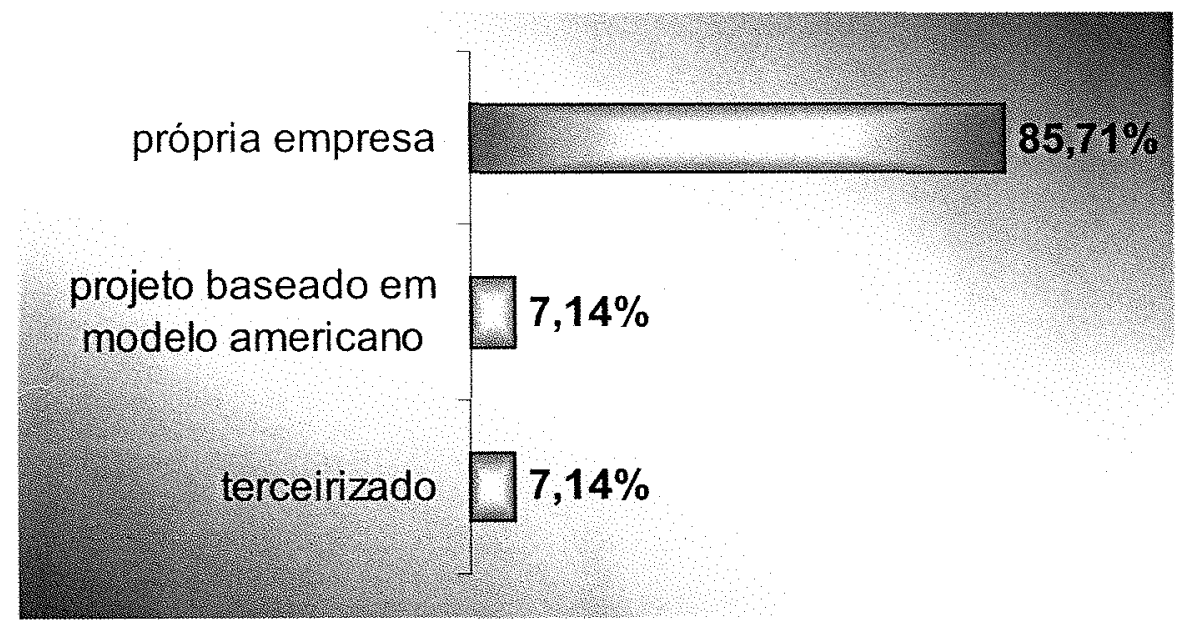

Figura 7 - Elaboração dos programas de educação ambiental.

Das empresas que elaboram o programa de educação ambiental, verifica-se que $61,54 \%$ não contam com apoio de nenhuma consultoria externa e apenas $38,46 \%$ contam com consultoria especializada (Tabela 3 ). 
Tabela 3. Apoio de consultoria externa.

\begin{tabular}{lcc}
\hline Empresa & sim & não \\
\hline Aracruz Celulose S.A. & $\mathrm{X}$ & \\
Bahia Sul Celulose S.A. & $\mathrm{X}$ & \\
CAF Santa Bárbara Ltda. & & $\mathrm{X}$ \\
CENIBRA Celulose Nipo - Brasileira S.A. & $\mathrm{X}$ & $\mathrm{X}$ \\
Duratex S.A. & & $\mathrm{X}$ \\
Eucatex S.A. Indústria e Comércio & & $\mathrm{X}$ \\
IKPA - Indústrias Klabin de Papel e Celulose & $\mathrm{X}$ & \\
International Paper do Brasil Ltda. & & $\mathrm{X}$ \\
Inpacel - Indústria de Papel Arapoti & & $\mathrm{X}$ \\
Lwarcel Celulose e Papel Ltda. & $\mathrm{X}$ & \\
Rigesa Celulose, Papel e Embalagens Ltda & & $\mathrm{X}$ \\
Ripasa SA Celulose e Papel & & $\mathrm{X}$ \\
Veracel Celulose S.A. & 5 & 8 \\
$\quad$ Total & 51,54 \\
\hline
\end{tabular}

Das empresas pesquisadas, $71,43 \%$ possuem um único programa de educação ambiental, conforme demonstrado na Figura 8.

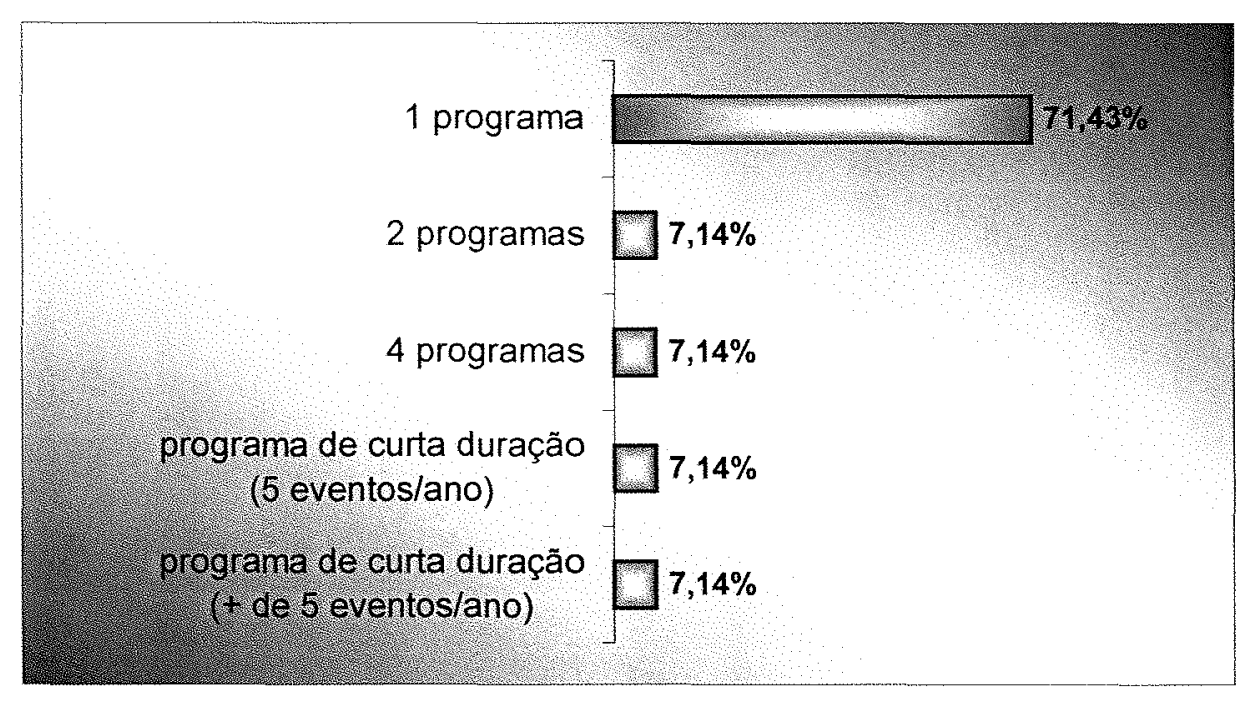

Figura 8 - Número de programas em andamento. 
Apenas uma empresa teve suas atividades de educação ambiental iniciadas há mais de 15 anos (1987). As demais (92,86\%) iniciaram o processo a partir de 1992, ano em que foi promovido pela UNESCO a ECO - 92 do Rio de Janeiro, marco significativo para as questões ambientais. Esses dados estão representados na Figura 9.

O advento da ECO-92 reforçou o surgimento de movimentos ambientalistas e intensificou as práticas em busca de alternativas ecologicamente saudáveis.

Por influência desta circunstância as empresas passaram, neste momento a incorporar seus programas de educação ambiental.

É necessário, como ressalva, atentar-se cuidadosamente para práticas relacionadas à ecologia apenas por modismos passageiros. Conhecimentos de áreas diversas como geografia, biologia, turismo, entre outras, foram assimilados de maneira pouco consistente às práticas ambientalistas.

$\dot{E}$ importante que as atuações nessa área sejam baseadas em conceitos éticos sólidos para que sejam assimiladas as condições técnicas, econômicas, políticas e morais vigentes. Será possível, assim, trilhar-se um caminho de desenvolvimento e auto-superação. 


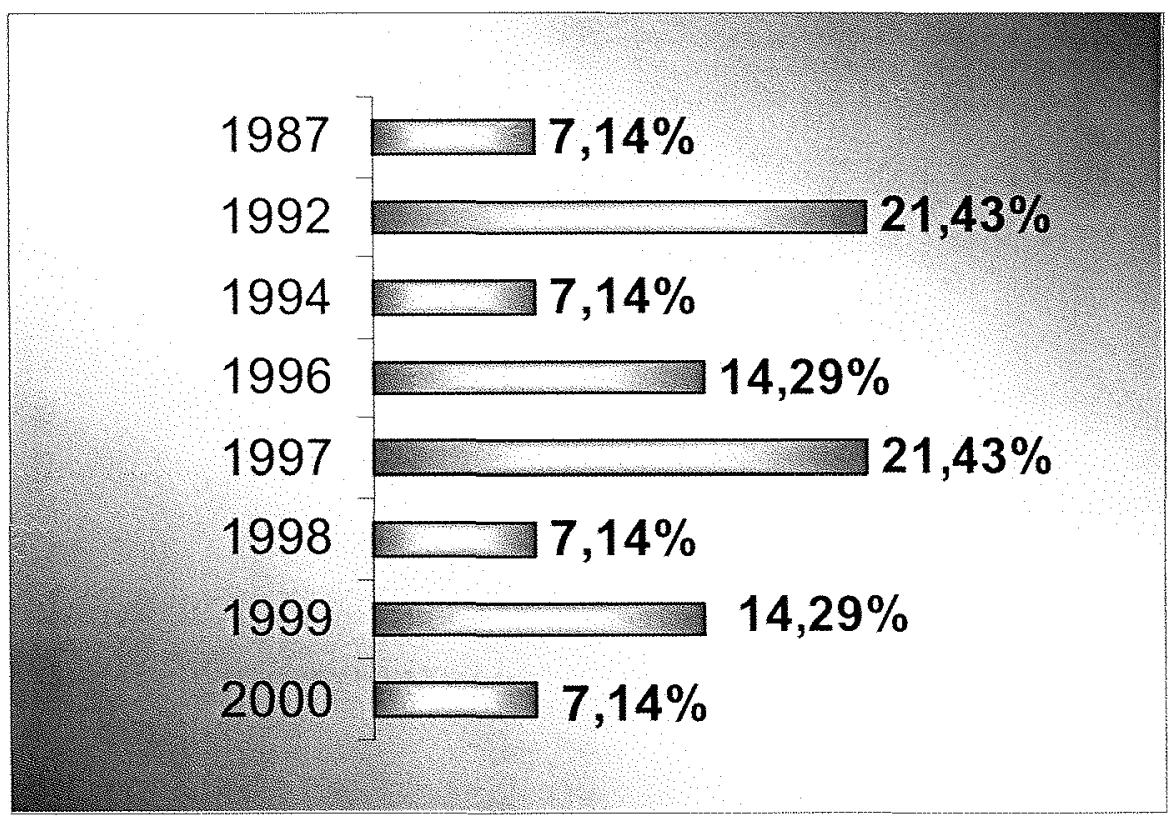

Figura 9 - Período em que o programa de educação ambiental está em andamento

Questionou-se também a respeito da elaboração de material educativo.

Das empresas pesquisadas, $57,14 \%$ elaboraram algum tipo de material educativo (folders, cartilhas, vídeos), conforme demonstrado na Tabela 4.

Tabela 4. Elaboração de material educativo.

\begin{tabular}{lcr}
\hline & $\mathrm{n} .^{\circ}$ de empresas & \multicolumn{1}{c}{$\%$} \\
\hline sim & 8 & 57,14 \\
não & 3 & 21,43 \\
não informou & 3 & 21,43 \\
Total & 14 & 100,00 \\
\hline
\end{tabular}


Este resultado é importante, pois demonstra o interesse das empresas na elaboração de material educativo.

Porém, cabe ressaltar que uma série de cuidados devem ser tomados quando da elaboração destes materiais.

Viezzer et al. (1996), quando analisaram 25 cartilhas sob a ótica da educação popular, ressaltaram algumas recomendações a partir dos pressupostos da educação ambiental definidos por ocasião da Conferência de Tbilisi. São elas:

"1. Quais os conhecimentos que [as cartilhas] trazem?

2. Que tipo de consciência trabalham?

3. Que atitudes estimulam?

4. Que habilidades aportam?

5. Quais as formas de participação sugeridas?"

Com base nisso, sugere-se atenção na elaboração de qualquer material que tenha finalidade educacional, buscando-se sempre o apoio de um profissional capacitado para tal.

\subsubsection{Público alvo, parceiros e atividades desenvolvidas com público externo}

$71,43 \%$ das empresas têm como público alvo a comunidade escolar, sendo que $85,71 \%$ trabalham com escolas de ensino fundamental da cidade onde está localizado o centro de educação ambiental, conforme Figura 10. 


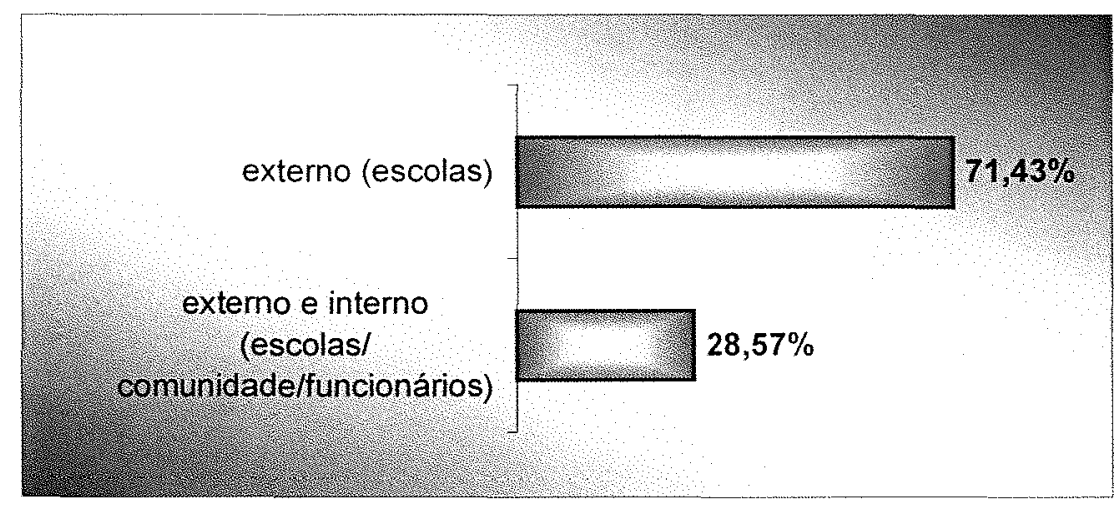

Figura 10 - Público alvo.

"(...) a mudança para tornar operações ecologicamente responsáveis depende da participação de todas as pessoas da empresa" (Callenbach e Capra, 1993, p.107).

Uma situação adequada seria a educação ambiental com postura ecodesenvolvimentista, onde o público alvo seria tanto o interno (empregados), quanto o externo (população do entorno, consumidores), conforme Braga, 1995, p.223.

A Tabela 5 demonstra que doze empresas têm como público alvo externo escolas de ensino fundamental da cidade onde está localizada, perfazendo um total de $85,71 \%$. Apenas 5 empresas $(35,71 \%)$ apresentam programas voltados para a comunidade do entorno da fábrica e familiares de seus funcionários. 
Tabela 5. Público externo atingido.

\begin{tabular}{lcc}
\hline & n. ${ }^{\circ}$ de empresas & $\%$ \\
\hline escolas de ensino fundamental da cidade & 12 & 85,71 \\
escolas de ensino médio da cidade & 10 & 71,43 \\
escolas de ensino fundamental da região & 7 & 50,00 \\
escolas de ensino médio da região & 7 & 50,00 \\
outros $^{14}$ & 6 & 42,86 \\
comunidade do entorno da fábrica $_{\text {familiares dos funcionários }}$ & 5 & 35,71 \\
\hline
\end{tabular}

Os programas de educação ambiental são caracterizados principalmente pelo atendimento ao público externo, dividindo-se em dois grupos distintos: escolas/professores e visitantes em geral.

Porém é importante que os programas sejam estendidos também a população do entorno e ao público interno, que são os funcionários $e$ fornecedores. Esse processo deve ser continuamente aprimorado na perspectiva da educação ambiental, sem negligenciar as características de participação, emancipação e valorização da diversidade, entre outros princípios, fundamentais à educação ambiental.

"É urgente que os processos educativos sejam mais abrangentes e essenciais cuidando prioritariamente da ampliação da consciência humana, possibilitando a percepção profunda da nossa condição de guardiões da vida na Terra. A consciência ecológica emergirá espontaneamente quando o sentido da unidade for tocado, ou seja, quando cada criatura sentir-se verdadeiramente vinculada a todas as formas de vida e aos mistérios da existência (...). A criança traz em si o forte vinculo com a natureza e está espontaneamente aberta para tornar-se 
um aprendiz de seus ensinamentos, basta que seja orientada para isso. A infância é um terreno fértil, para desenvolver o aprendizado da harmonia entre as diversas formas de vida da Terra" (Izenildes Lima, citado por Gadotti, 2000, p.178).

O questionário encaminhado às empresas pesquisadas abordou temas relativos às atividades de educação ambiental realizadas com o público externo. Verificou-se que 13 empresas (92,86\%) tratam dos temas relacionados à fauna e flora. $85,71 \%$ ressaltam, em suas práticas educativas a responsabilidade sócio-ambiental de cada cidadão e 78,57\% discutem a qualidade ambiental da região. A responsabilidade sócio-ambiental da empresa e de cada um de seus empregados é discutida por $50 \%$ e $35,71 \%$ discutem a poluição e tecnologias utilizadas na fábrica e/ou floresta (Figura 11).

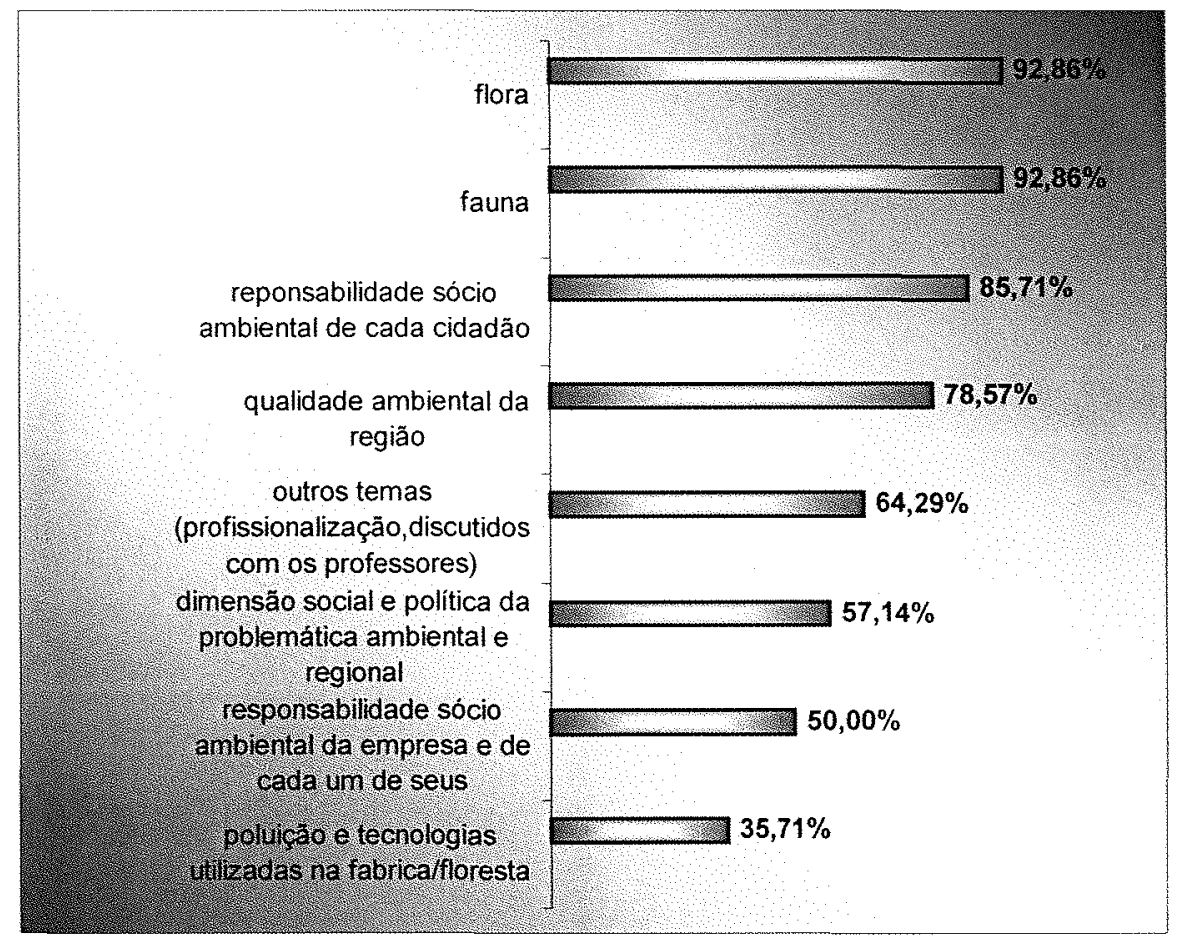

Figura 11 - Temas abordados nas atividades com público externo. 
Esses aspectos das políticas ambientais que são consubstanciados nos programas educativos referem-se a propostas gerais de gestão empresarial, cuja abrangência transcende os limites de atuação de cada empresa.

Os temas abordados pelas empresas devem ser tratados numa dimensão educacional que estimule a busca de uma consciência crítica da relação humana com o meio sócio-ambiental. A verdadeira pedagogia visa a emancipação da consciência humana de modo a atingir um pensar autônomo e criativo.

Os programas educativos têm como público alvo, na maioria das empresas pesquisadas, a faixa etária que varia entre 7 e 16 anos. Os temas devem incluir dinâmicas pedagógicas que estimulem o crescimento $e$ aprendizado pessoais como grupos, discussões, danças, teatro e festividades buscando uma conscientização ecológica. Assim será reforçado o papel da empresa na formação das crianças e na educação ambiental.

Quanto ao número de visitantes aos centros de educação ambiental, verifica-se que $42,86 \%$ das empresas atingem mais de 3.000 pessoas ao ano, sendo que, destes, $21,43 \%$ tem uma média acima de 4.100 , conforme demonstrado na Figura 12.

Uma empresa informa que, além dos 4.000 participantes dos programas internos, ainda atinge 60.000 externamente trabalhando a comunidade do entorno (dados coletados de comentários no questionário). 


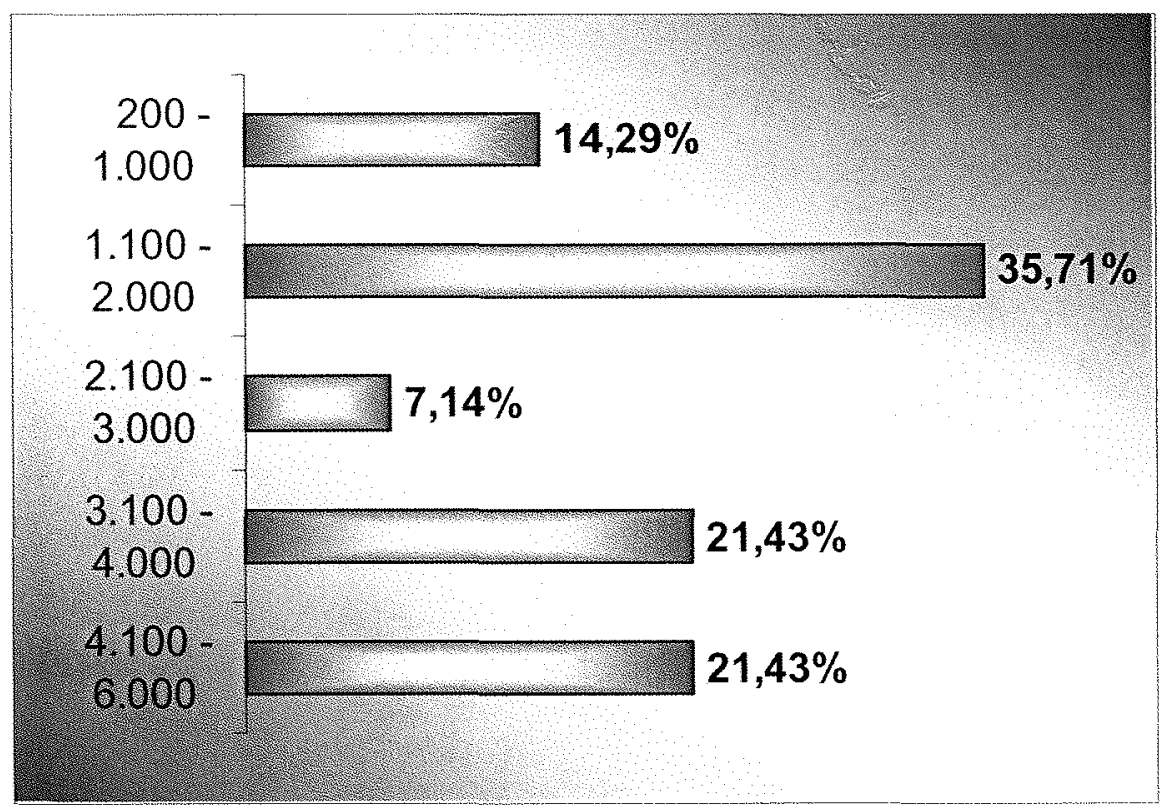

Figura 12 - Média do número de participantes por ano.

Duas empresas responderam que a eficiência do trabalho de educação ambiental está relacionada com o maior número de visitantes aos programas. No entanto, o que deve ser buscado é uma relação de qualidade aos visitantes. O retorno de um determinado público pode oferecer condições mais satisfatórias de aplicabilidade e avaliação destes programas. O reencontro propicia aos educadores a percepção quanto ao que foi assimilado pelos participantes em visitas anteriores e um número reduzido de pessoas pode favorecer uma maior aproximação de cada participante.

Esses fatores devem ser levados em consideração na elaboração de um programa de educação ambiental quando se estabelecem os objetivos que se pretende alcançar.

Analisando os questionários, verifica-se que $50 \%$ da empresas trabalham em parcerias com órgãos públicos (prefeituras, secretarias municipais e estaduais), Banco Nacional de Desenvolvimento Econômico e 
Social (BNDES), organizações não governamentais (ONGs) e Universidades. Os dados estão representados na Tabela 6.

Tabela 6. Parceiros.

\begin{tabular}{ccc}
\hline & n. ${ }^{\circ}$ de empresas & $\%$ \\
\hline sim & 7 & 50,00 \\
não & 7 & 50,00 \\
Total & 14 & 100,00 \\
\hline
\end{tabular}

Através dessas parcerias, encontram-se projetos relacionados a microbacias hidrográficas, programas de reintrodução de aves, parcerias agrícolas, convênios com cooperativas de agricultores, levantamentos de fauna, flora e fitossociologia, entre outros. Esses dados são importantes, pois demonstram o interesse das empresas em apoiarem projetos relacionados às questões ambientais.

\subsubsection{Continuidade, acompanhamento e avaliação dos programas de educação ambiental}

Verifica-se que $50 \%$ das empresas possuem programas que tem como proposta pelo menos mais um retorno dos participantes às atividades de educação ambiental (Tabela 7).

Tabela 7. Continuidade dos programas de educação ambiental.

\begin{tabular}{ccc}
\hline & $\mathrm{n}^{\circ}$ de empresas & $\%$ \\
\hline $\operatorname{sim}$ & 7 & 50,00 \\
não & 7 & 50,00 \\
Total & 14 & 100,00 \\
\hline
\end{tabular}


“(...) necessidade de tempo para amadurecimento, crescimento, dedicação, amor, para se constituir e fixar uma maneira de ver e sentir a realidade, envolvendo todos os interessados, tornandoos co-participantes de todo processo" (Cascino, 1999, p.91).

Qualquer trabalho educacional deve propiciar condições de emancipação do ser humano, e esse processo só acontece na medida em que se oferecem oportunidades e momentos para um mergulho em si próprio. Os processos de continuidade deveriam acontecer dentro de uma série de atividades sistematizadas, que pudessem ser acompanhadas e analisadas em profundidade, criando-se situações favoráveis para momentos de reflexão e conhecimento de si próprio e de seu entorno.

Das 14 empresas, 9 (64,29\%) procuram desenvolver algum tipo de contato e/ou acompanhamento aos visitantes após o desenvolvimento das atividades, conforme demonstrado na Figura 13.

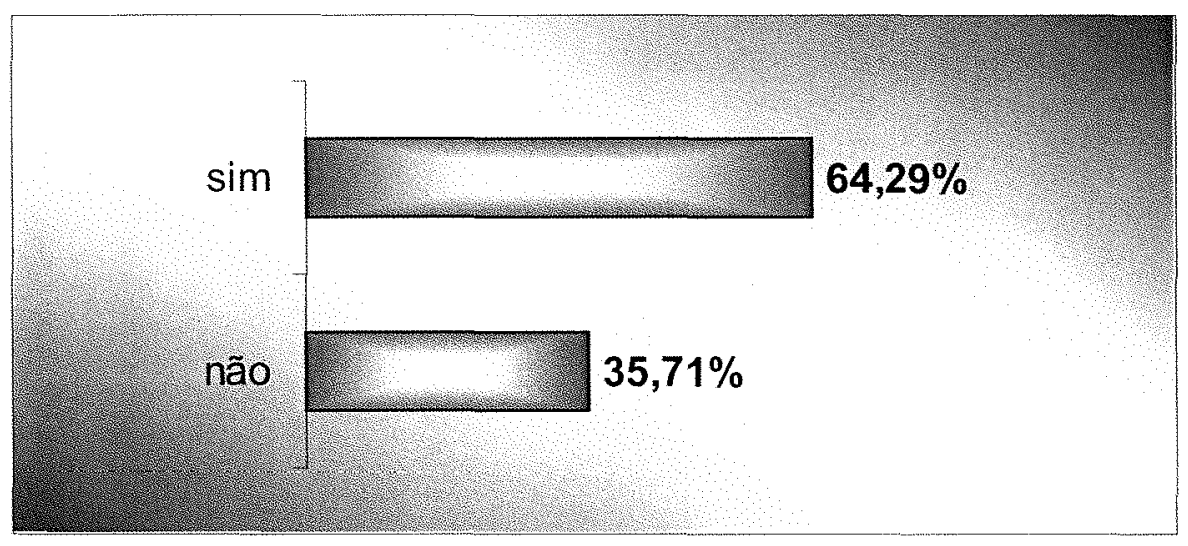

Figura 13 - Acompanhamento das atividades desenvolvidas.

"Nos programas de educação ambiental, a avaliação deverá ser global. (...). Um dos principais pontos consistiria em avaliar a coerência interna dos programas, e dizer, se suas metas e objetivos, métodos pedagógicos e estratégias de avaliação do aluno são compativeis. (...) Este tipo de avaliação deveria iniciar- 
se no momento em que se começa a elaborar o programa, continuando nas primeiras fases e depois destas. Este trabalho não é fácil, já que a avaliação é uma operação em que se intervem juízos de valor. O grau de coerência interna das metas, objetivos, pedagogia e avaliação de resultados deve ser julgado - pelo menos a princípio - de forma subjetiva. Todos os envolvidos na elaboração e aplicação deverão estar conscientes a todo o momento da necessidade de avaliação e deverão participar dela. Também é preciso contar com a presença dos serviços de um ou vários assessores profissionais com experiência, que se encarregarão de analisar o programa neste sentido. Serão sinalizadas as incoerências detectadas, e se prosseguirá seguidamente a revisão do programa" (Hungerford, 1992, p.34) - traduzido do espanhol.

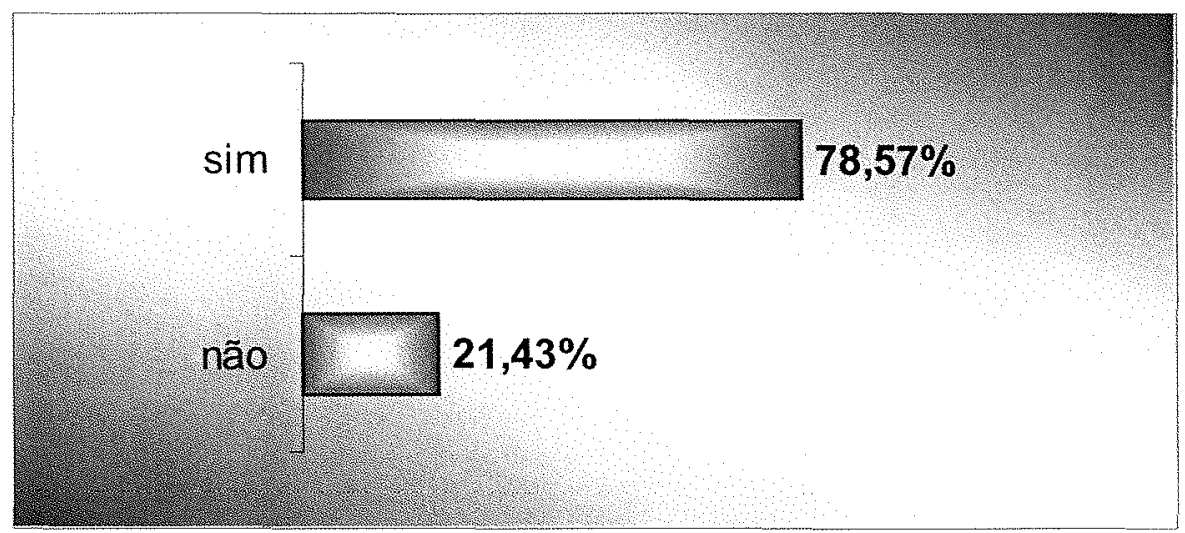

Figura 14 - Avaliação de resultados das atividades desenvolvidas.

$78,57 \%$ das empresas, ou seja 11 , utilizam questionários, redações e desenhos como métodos de avaliação de resultados (Figura 14).

Estes métodos de avaliação não podem ser considerados satisfatórios, já que, questionários, redações e/ou desenhos devem ser utilizados acompanhados de discussões organizadas sobre idéias e sentimentos, 
facilitando a compreensão dos temas em questão, possibilitando também, a criação de situações onde participantes e organizadores possam expressar-se, favorecendo o crescimento do programa. Esta conclusão é reforçada quando das 11 empresas que dizem possuir processos de avaliação, observa-se que 3 questionários demonstraram preocupação com a insuficiência e ineficácia de seus métodos, solicitando sugestões para aprimoramento dos mesmos.

\subsubsection{Atividades de educação ambiental com os funcionários}

"Uma educação ambiental compatível com a postura ecodesenvolvimentista, deveria possuir como principais objetivos despertar o sentimento de corresponsabilidade e facilitar o exercício da cidadania. (...) A temática centrar-se-ia nas relações entre o sistema produtivo, a sociedade e o meio ambiente. Seriam abordados temas como: as relações entre poluição e tecnologias utilizadas; a responsabilidade sócio ambiental da empresa e de cada um de seus empregados; a responsabilidade sócio-ambiental de cada cidadão; a divulgação sistemática dos índices de monitoramento da qualidade ambiental na região;a dimensão social e política da problemática ambiental regional" (Braga, 1995, p.223). 


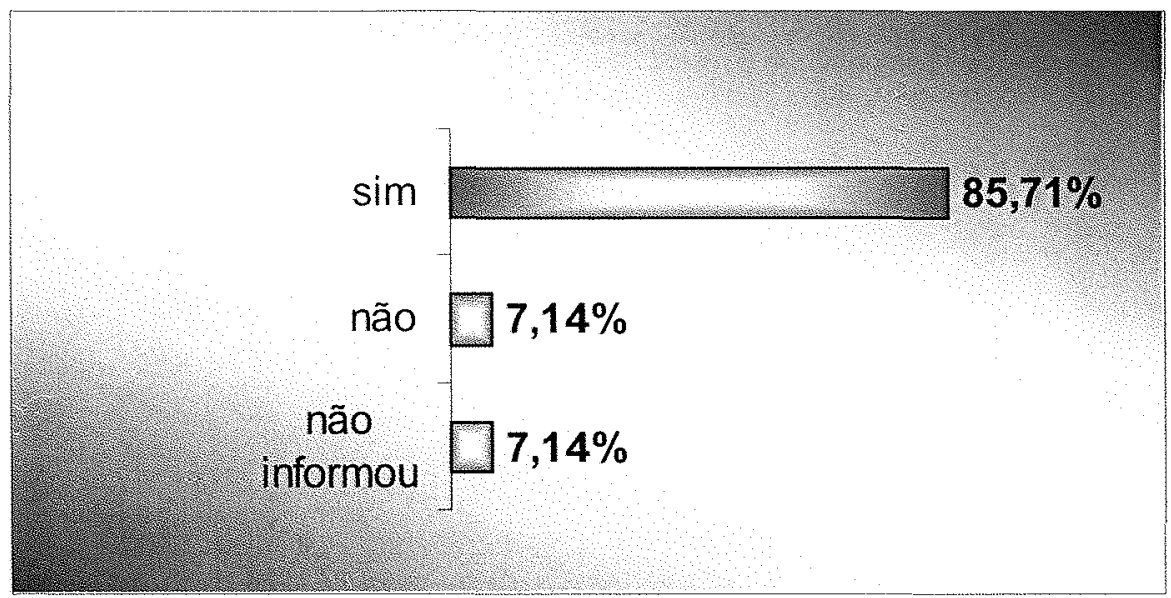

Figura 15 - Empresas que possuem atividades de educação ambiental com os funcionários.

Das 14 empresas, verifica-se que $85,71 \%$ desenvolvem atividades de educação ambiental com os funcionários, conforme Figura 15. Desse total, todas realizam cursos de capacitação com palestrantes internos e 58,33\% utilizam-se de palestrantes convidados. $83,33 \%$ das empresas incluem as comemorações de datas especiais como principal atividade de educação ambiental. Nenhuma empresa desenvolve atividades com os funcionários junto a comunidade do entorno da fábrica. Todos esses dados estão demonstrados na Figura 16.

Os outros tipos de atividades desenvolvidas com funcionários referemse a campanhas e palestras sobre economia de energia e de papel, coleta seletiva e reciclagem de lixo e desenvolvimento sustentável, entre outras. 


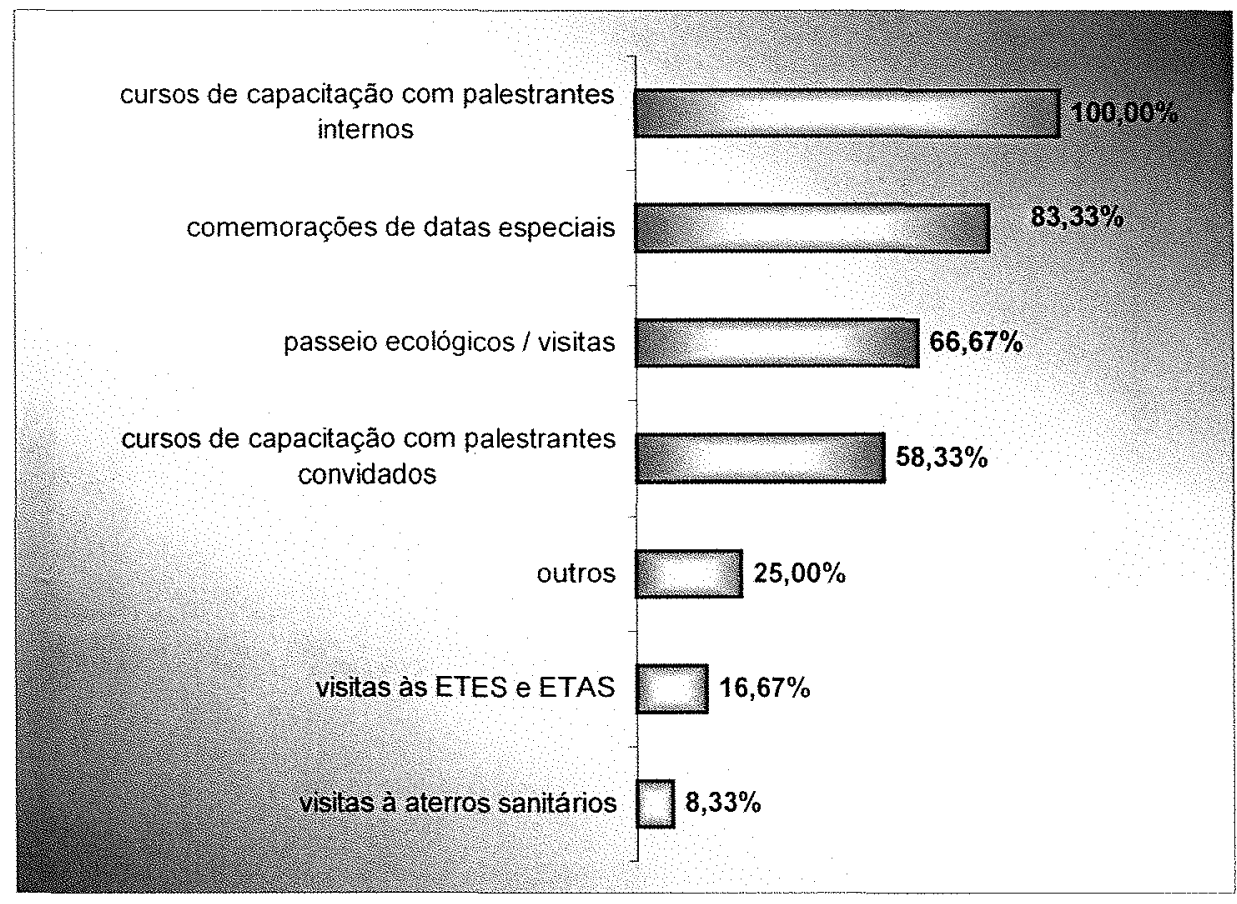

Figura 16 - Tipos de atividades desenvolvidas com os funcionários.

Destacam-se, como temas mais abordados nas atividades desenvolvidas com os funcionários, os referentes à fauna e flora, com $83,33 \%$ das empresas, e sobre a responsabilidade sócio-ambiental da empresa e de cada um de seus empregados com 75,00\%, conforme Figura 17.

Assuntos relacionados à fauna e flora são indiscutivelmente importantes, mas por si só não são suficientes. A educação ambiental em empresas é relevante quando coloca em pauta temas do cotidiano. Os programas de conservação de fauna e flora devem ser incorporados ao sistema, sendo, portanto, mais um instrumento para se fazer educação ambiental, e não um método. 


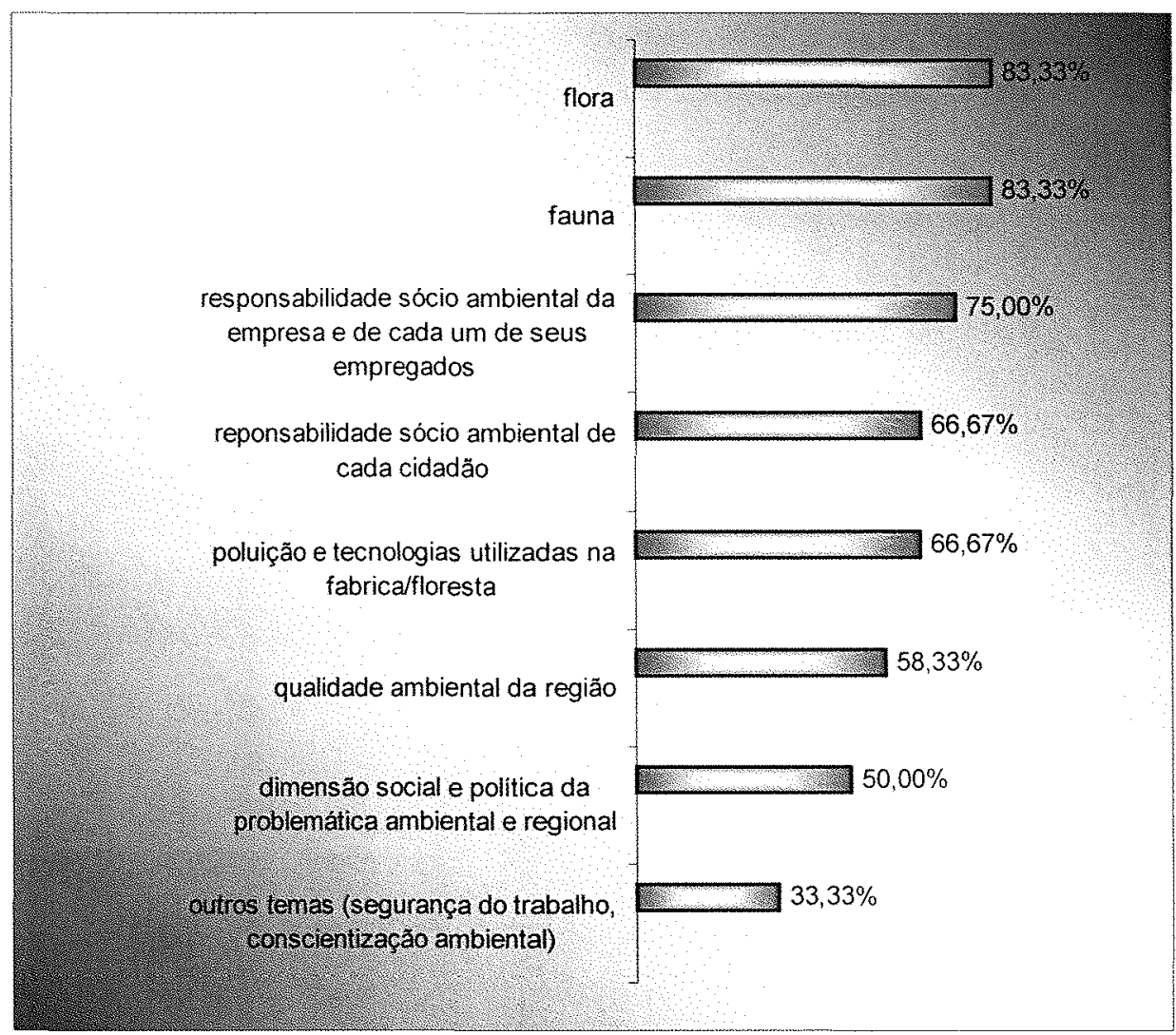

Figura 17 - Temas abordados nas atividades com os funcionários.

As empresas responderam questões sobre envolvimento de seus funcionários nas atividades relacionadas à educação ambiental.

Nota-se que $83,33 \%$ das empresas têm a participação de sua administração na programação de educação ambiental. O mesmo número de empresas tem o seu pessoal de produção engajado nas práticas educativas. $75 \%$ têm a gerência envolvida e somente $25 \%$ incluem a diretoria no processo (Figura 18).

Os programas de educação ambiental, visando uma conscientização ecológica, devem iniciar-se de forma organizada, descentralizada e com a participação de todos 
"A educação ambiental deve ter como objetivos alcançar uma transformação profunda dos funcionários dentro da organização, do presidente ao chão de fábrica" (Valle, 1995, p.11).

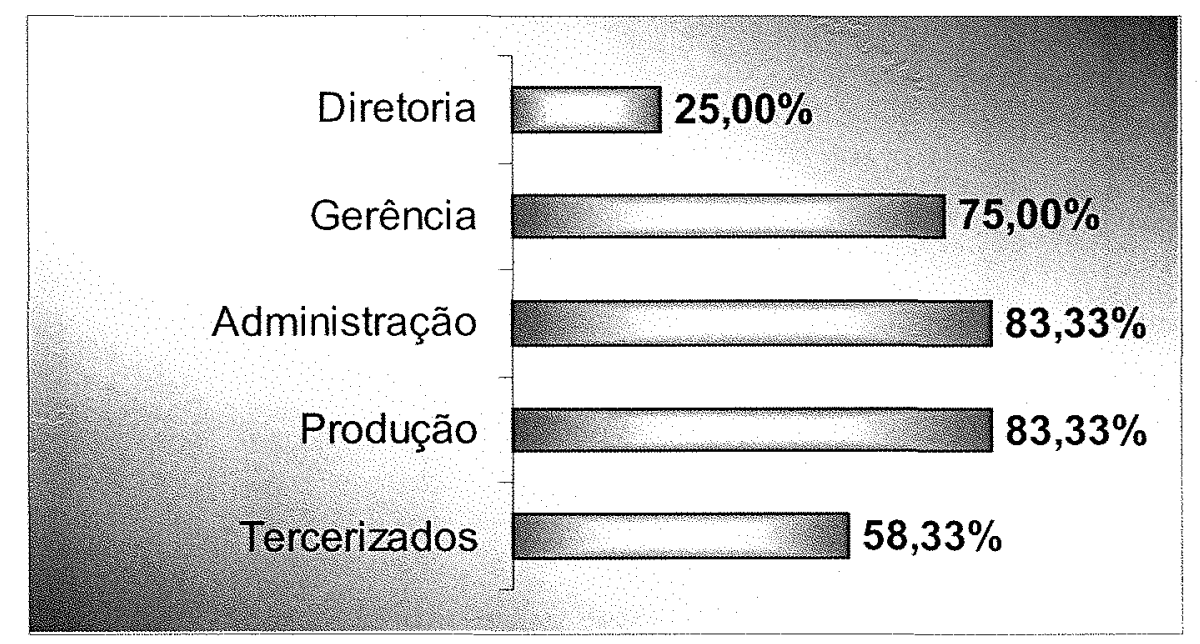

Figura 18 - Estrutura administrativa segundo o número de empresas em que os funcionários participam das atividades relacionadas à educação ambiental.

A Figura 18 também aponta que ainda não existe participação efetiva de todos os funcionários da organização nas atividades de educação ambiental. Deve-se ressaltar a importância do engajamento de todo o corpo administrativo e operacional da empresas no processo educativo.

\subsubsection{Certificação}

Das 14 empresas pesquisadas, 9 possuem algum tipo de certificação, ou seja, $64,28 \%$.

Observa-se ainda, que $28,57 \%$ das empresas possuem o selo do FSC, que só é concedido para empresas do setor florestal e 6 empresas, ou seja, $42,86 \%$ possuem a ISO 14001, conforme demonstrado na Figura 19. 


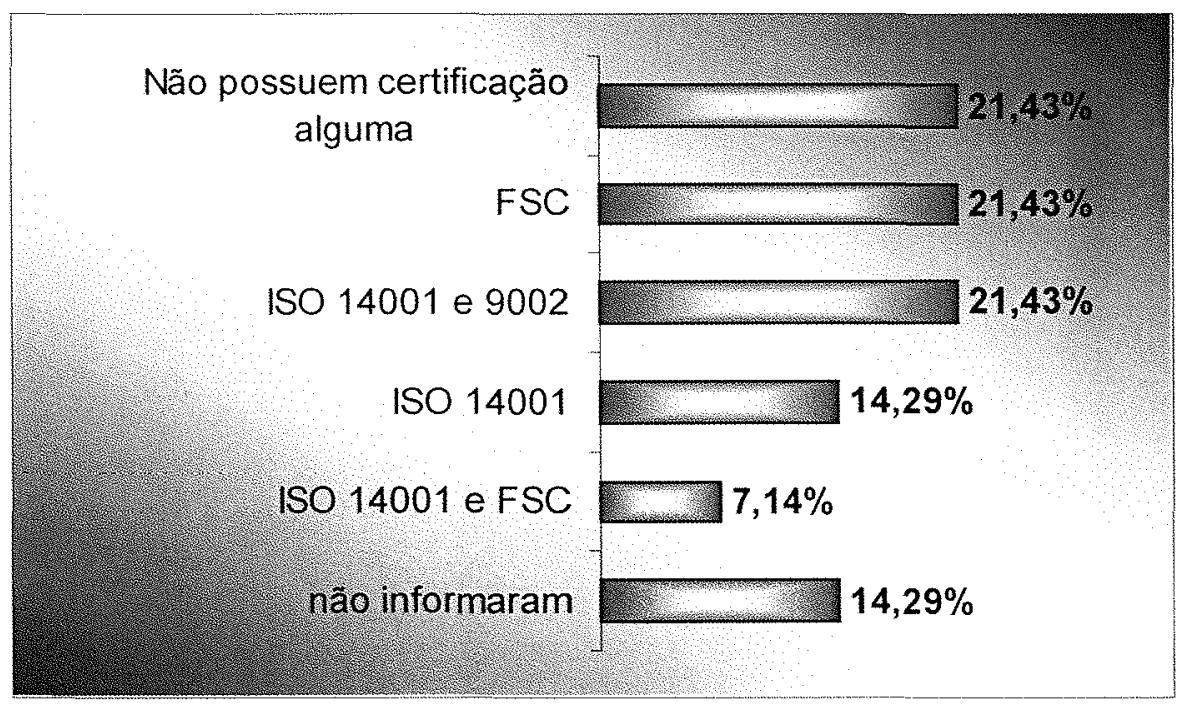

Figura 19 - Certificação.

"A obtenção da certificação ambiental por uma empresa e as condições para sua manutenção dependerão, inequivocadamente, da participação consciente de seus funcionários e fornecedores. A conscientização e o adequado treinamento dos funcionários têm importância vital nesse processo pois, muitas vezes, é através de erros operacionais que podem ser gerados os piores resíduos e provocados os maiores acidentes. Pela educação ambiental se pode acelerar esse processo de conscientização dos indivíduos, tanto internos como externos à empresa, possibilitando assim chegar mais rapidamente a almejada certificação por uma entidade credenciada" (Valle, 2000, p.13-14). 


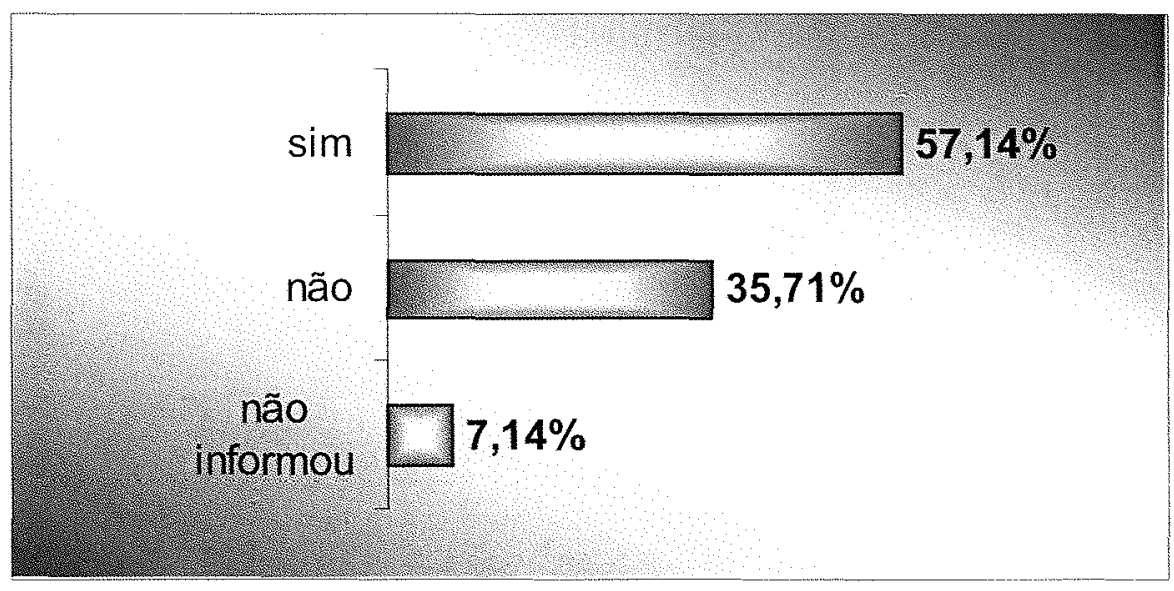

Figura 20 - Relação do programa de educação ambiental com a certificação.

$57,14 \%$ das empresas entendem que os programas de educação ambiental contribuem para a obtenção da certificação ou da recertificação.

Outras, que equivalem a $35,71 \%$, informam que os programas de educação ambiental não têm relação com a certificação, pois foram implantados antes de sua obtenção, conforme demonstrado na Figura 20.

Esses programas de educação ambiental quando implementados pelas empresas, podem contribuir para a obtenção da certificação.

É importante salientar que, os programas devem ser dirigidos aos funcionários, e estes devem ser diferenciados de treinamentos, buscando a compreensão do sentido dos valores sociais, e a conquista de um sentimento de profundo interesse pelo meio ambiente, de forma a contribuir para a sua proteção e qualidade. 
Dora Abreu (2000, p.79) diz que se a educação ambiental acontecer no âmbito do Sistema de Gestão Ambiental, ela será capaz de:

"(..) sensibilizar as pessoas, a ponto destas se tornarem responsáveis, não só pelas questões ambientais de suas empresas, mas, por tudo aquilo que possa causar impacto sobre a qualidade de vida dos diversos seres da Terra. A educação ambiental autêntica dispensa atestados e não precisa de papéis assinados para evidenciar sua presença, pois, quando ela chega, fica. (...) A própria postura das pessoas já é um atestado". 


\section{CONSIDERAÇÕES FINAIS}

O presente trabalho procurou analisar os programas de educação ambiental efetivados por empresas do setor florestal e contribuir para o seu aprimoramento.

O processo de educação ambiental deve iniciar-se de forma organizada, sendo fundamental a participação de todos os funcionários. Devese incentivar o desenvolvimento de uma criticidade que possibilite o repasse criativo das informações assimiladas, objetivando a emancipação da consciência humana, na busca de um pensar autônomo.

É de suma importância que, o desenvolvimento dos programas de educação ambiental, objetivem uma interação do público interno (funcionários, fornecedores, etc) e público externo (população do entorno, consumidores, etc).

As empresas que investem em programas dirigidos somente ao público externo, negligenciam a necessidade de incluir entre seus objetivos, os trabalhos de educação ambiental em seu próprio ambiente, maneira pela qual, poderiam aferir "in loco" a praticidade e eficácia dos programas ali desenvolvidos.

Deve-se criar na empresa um alto espirito participativo. As verdadeiras mudanças de comportamento que tornam as operações ecologicamente saudáveis dependem da participação e envolvimento de todos os protagonistas envolvidos no processo.

Os profissionais que trabalham com educação ambiental, devem estar conectados em profundidade com todos os elementos, estruturas e funções 
dos diferentes temas abordados, que incluem, necessariamente, uma preocupação com os direitos humanos. Devem familiarizar-se com as técnicas utilizadas na resolução de problemas, fazendo com que os participantes desenvolvam sua capacidade de observação, reconheçam e analisem dados, formulando hipóteses, deduções e previsões.

Os programas de educação ambiental devem ter a preocupação de gerar continuidade às atividades realizadas. Os processos de continuidade, decorrem da sistematização de uma série de atividades, que poderão ser acompanhadas e analisadas detalhadamente, favorecendo o surgimento de situações para reflexão e auto conhecimento.

No que tange aos processos de avaliação, esses são essenciais, na medida em que podem propiciar discussões organizadas sobre idéias e sentimentos, facilitando a compreensão dos temas estudados, favorecendo assim, o desenvolvimento do programa.

Estes programas quando implementados pelas empresas, podem contribuir para a obtenção da certificação ambiental. Os programas de educação ambiental devem ser diferenciados dos programas de treinamento, pois objetivam a compreensão do sentido dos valores sociais e a conquista de um sentimento de profundo interesse pelo meio ambiente, de forma a contribuir para a sua proteção e qualidade.

Estabelecendo-se como prioridade, a educação ambiental, na administração das empresas, pode-se, a partir de um planejamento consciente e adequado, envolver a participação de todos em um conjunto de ações sistematizadas e integradas que, certamente, contribuirão para o efetivo sucesso do programa de educação ambiental do próprio Sistema de Gestão Ambiental (SGA).

$\mathrm{Na}$ definição dos critérios de escolha dos programas de educação ambiental, as empresas deparam-se com questões éticas que fundamentam seu papel social. A educação ambiental é uma ferramenta necessária e 
importante para viabilização de muitos aspectos de responsabilidade social das empresas.

Portanto é importante contribuir para que o estado da arte da educação ambiental nas empresas seja aprimorado. As propostas do Tratado de Educação Ambiental para Sociedades Sustentáveis e Responsabilidade Global, podem não ser passiveis de realização plena, mas são referências para práticas críticas e construtivas, possíveis dentro dos moldes da realidade presente.

A consciência dos limites de cada situação envolvida na prática educativa e a clareza sobre uma pedagogia plenamente engajada no processo de desenvolvimento humano, pode apontar para a direção de uma educação ambiental que possibilite uma relação libertadora e emancipatória. 
ANEXOS 


\section{ANEXO A - Carta enviada às empresas.}

São Paulo, ..... de de $20 \ldots$.

Prezado Sr.

Apresentamos anexo um questionário que tem por finalidade coletar dados dos PROGRAMAS DE EDUCAÇÃO AMBIENTAL existentes nas empresas do setor florestal com o intuito de identificar e analisar o perfil dos programas existentes e também verificar qual a contribuição que os mesmos tem proporcionado aos públicos a que se dirigem.

Trata-se de uma pesquisa em nível de pós-graduação (mestrado) que tem o objetivo de buscar propostas para elaboração de programas de Educação ambiental que contribuam nos processos de Gestão Ambiental e tem também a intenção de colaborar com uma maior interação entre as empresas do setor florestal.

O desenvolvimento do trabalho está sendo realizado através do curso de pós-graduação em Recursos Florestais da Escola Superior de Agronomia Luiz de Queiroz da USP, junto ao Departamento de Ciências Florestais e está sob a orientação do professor Dr. Dalcio Caron.

Uma vez concluída a dissertação, os autores assumem um compromisso de enviar um relatório contendo os dados coletados e analisados.

Esperamos poder contar com a colaboração da empresa. A Eng. Agrônoma Márcia Celestino Macedo, uma das autoras do projeto, entrará em contato com V.Sa. para fornecer maiores informações sobre a pesquisa, bem como para negociar a possibilidade de aplicar pessoalmente o questionário.

Atenciosamente,

Edward Fagundes Branco

Gerente Administrativo e de Desenvolvimento 


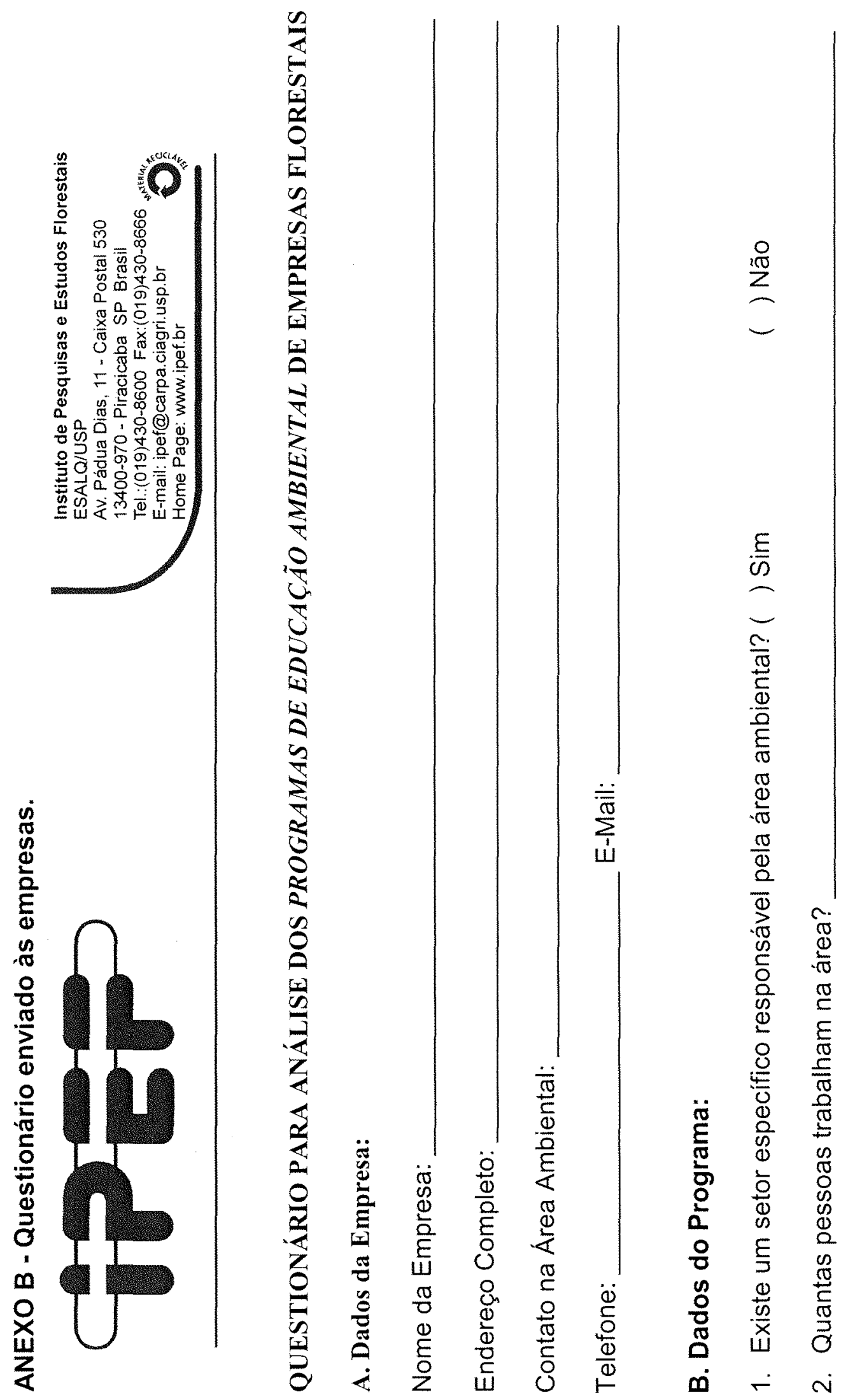




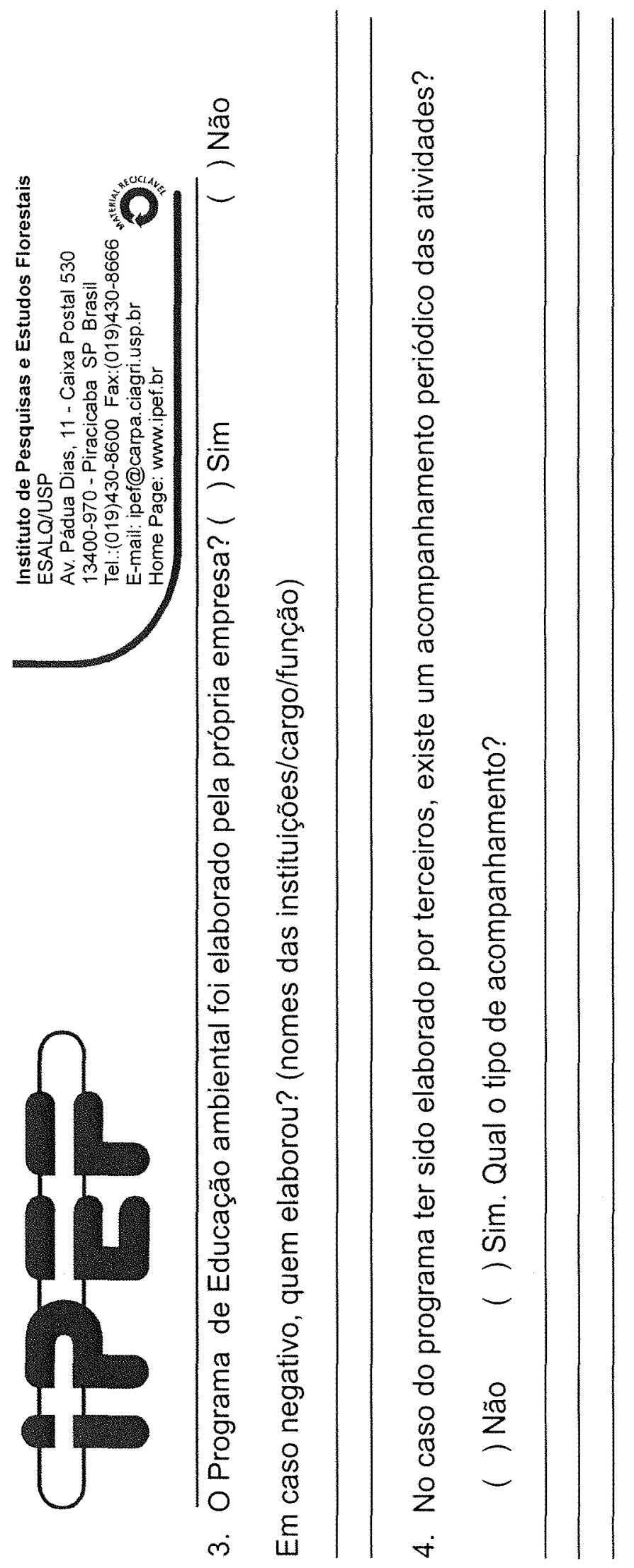




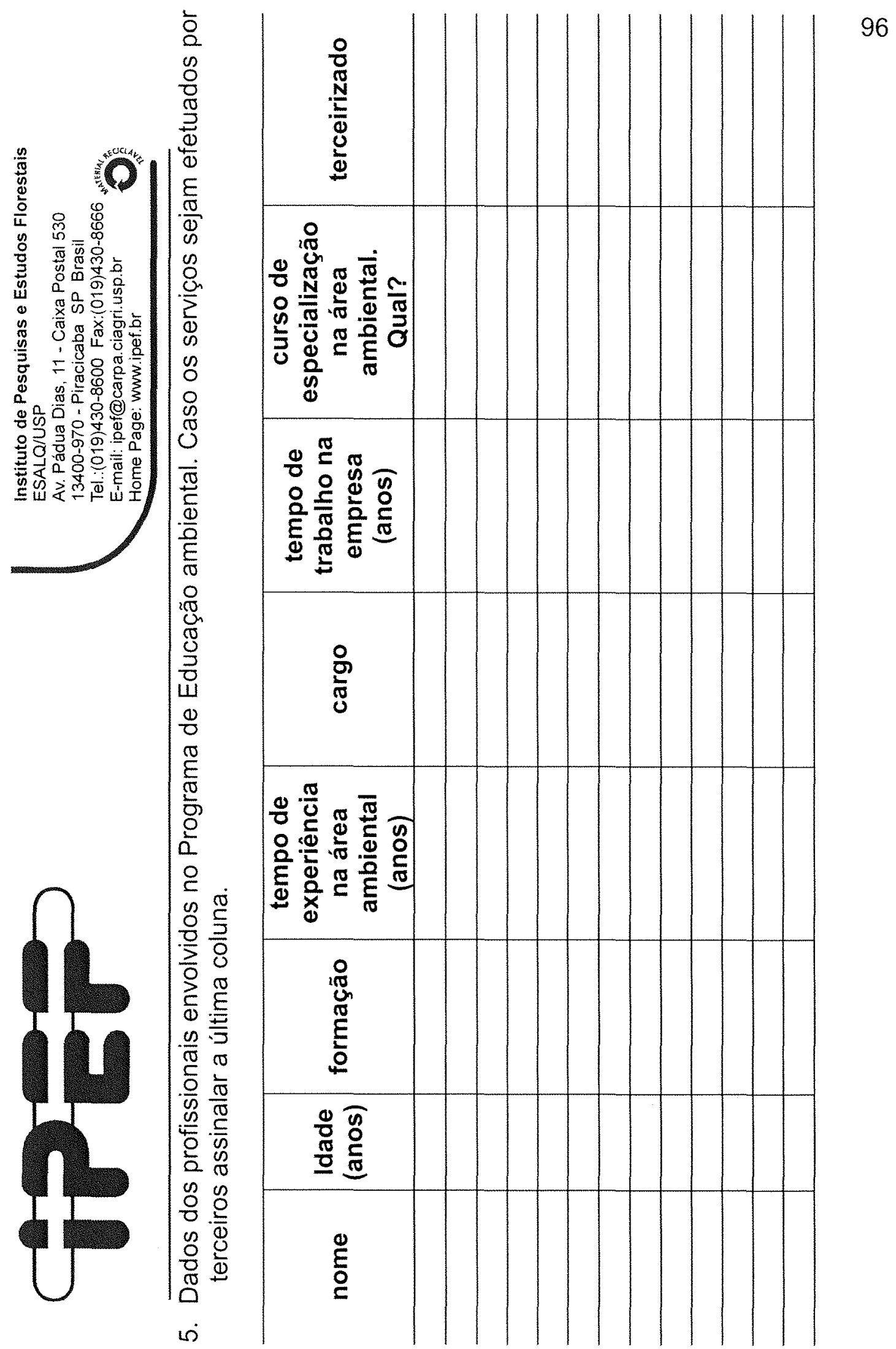




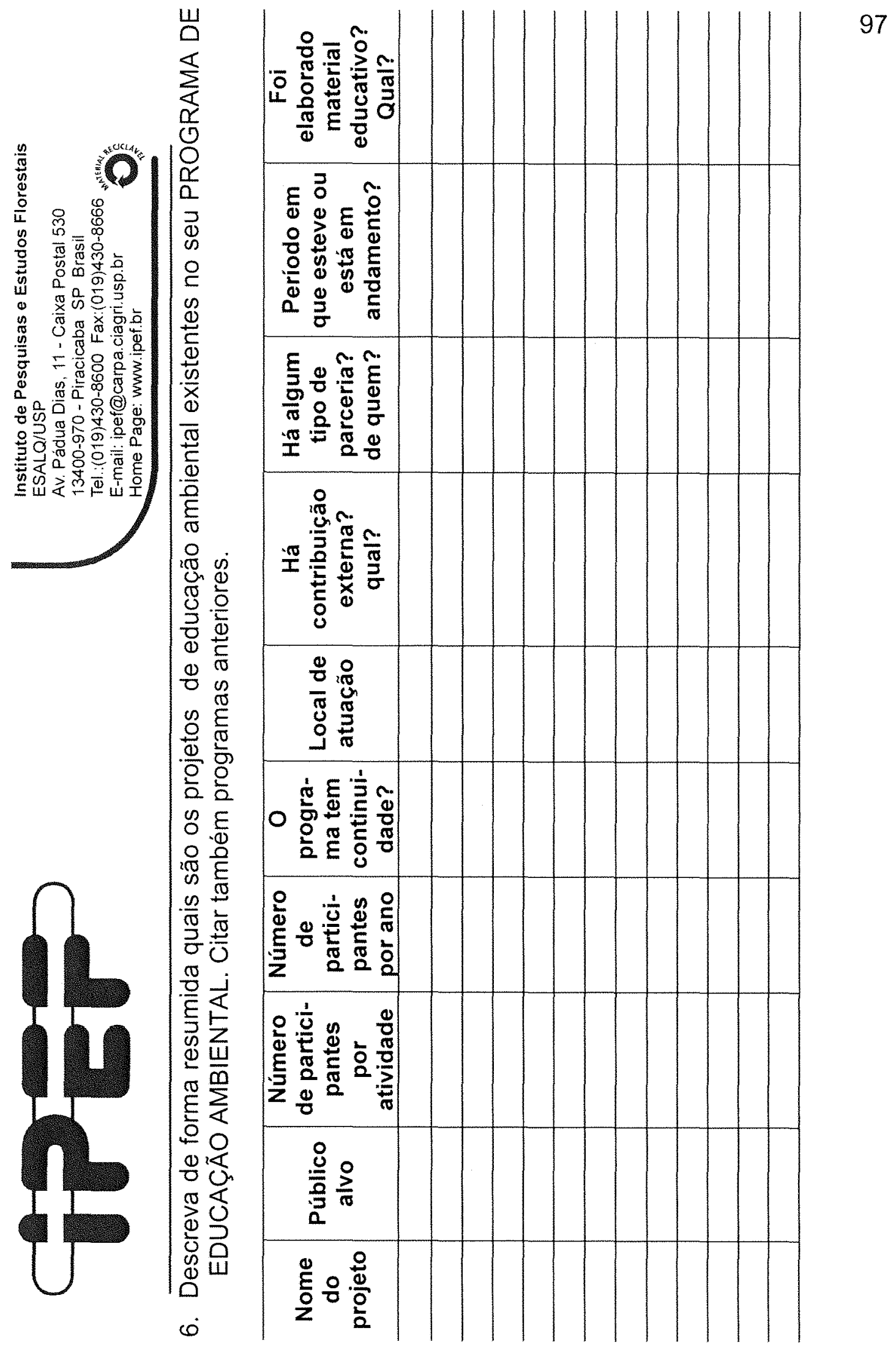



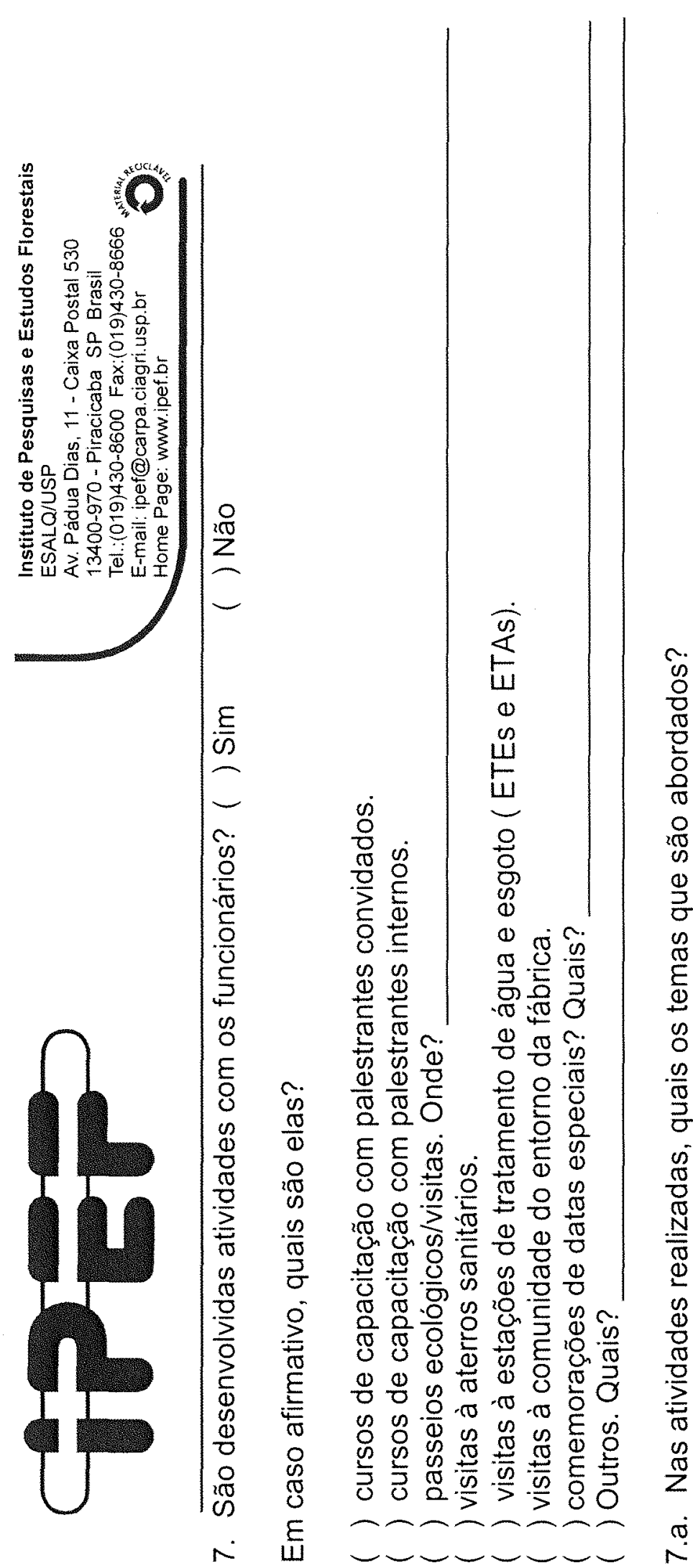

용

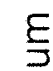

$\frac{\pi}{0}$

ర

$\stackrel{0}{0}$

(1) 0

कृ 응

ชั

은 융

$\left.\frac{\theta}{\sigma} \delta\right)$

एक 00

ज त

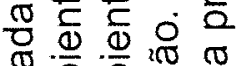

N $\frac{\pi}{2} \cdot \frac{\pi}{0}$

E $\frac{E}{\sigma} \frac{E}{\sigma}$

แ $\frac{0}{0} \cdot \frac{0}{0} \frac{0}{0}$

б.

응 \& $\stackrel{1}{0} \frac{1}{0}$

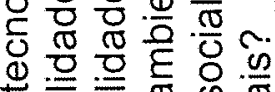
흥

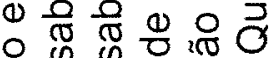
खण $\mathscr{E}$ 它 $\frac{1}{2}$ 응 की

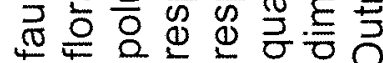




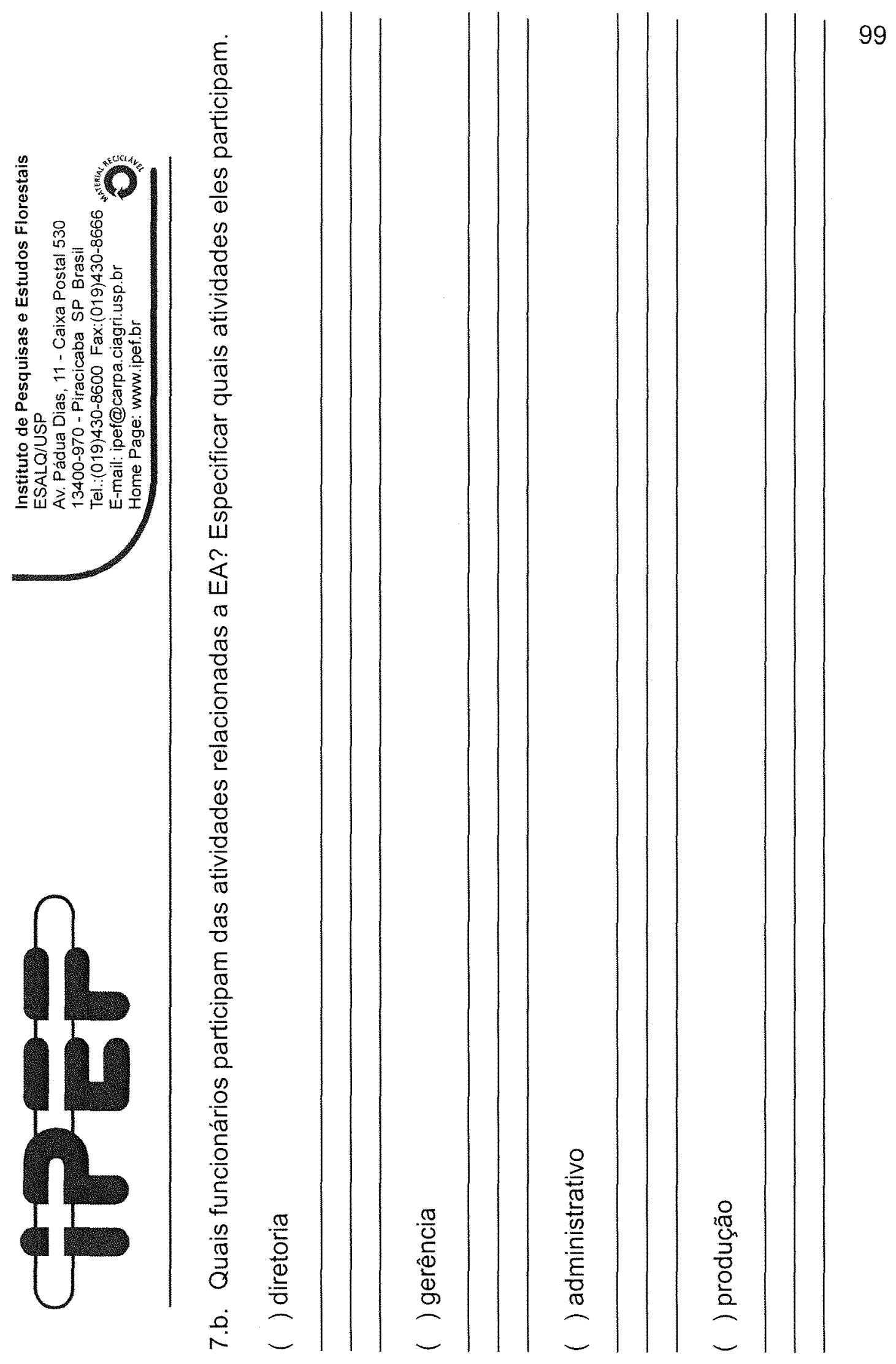




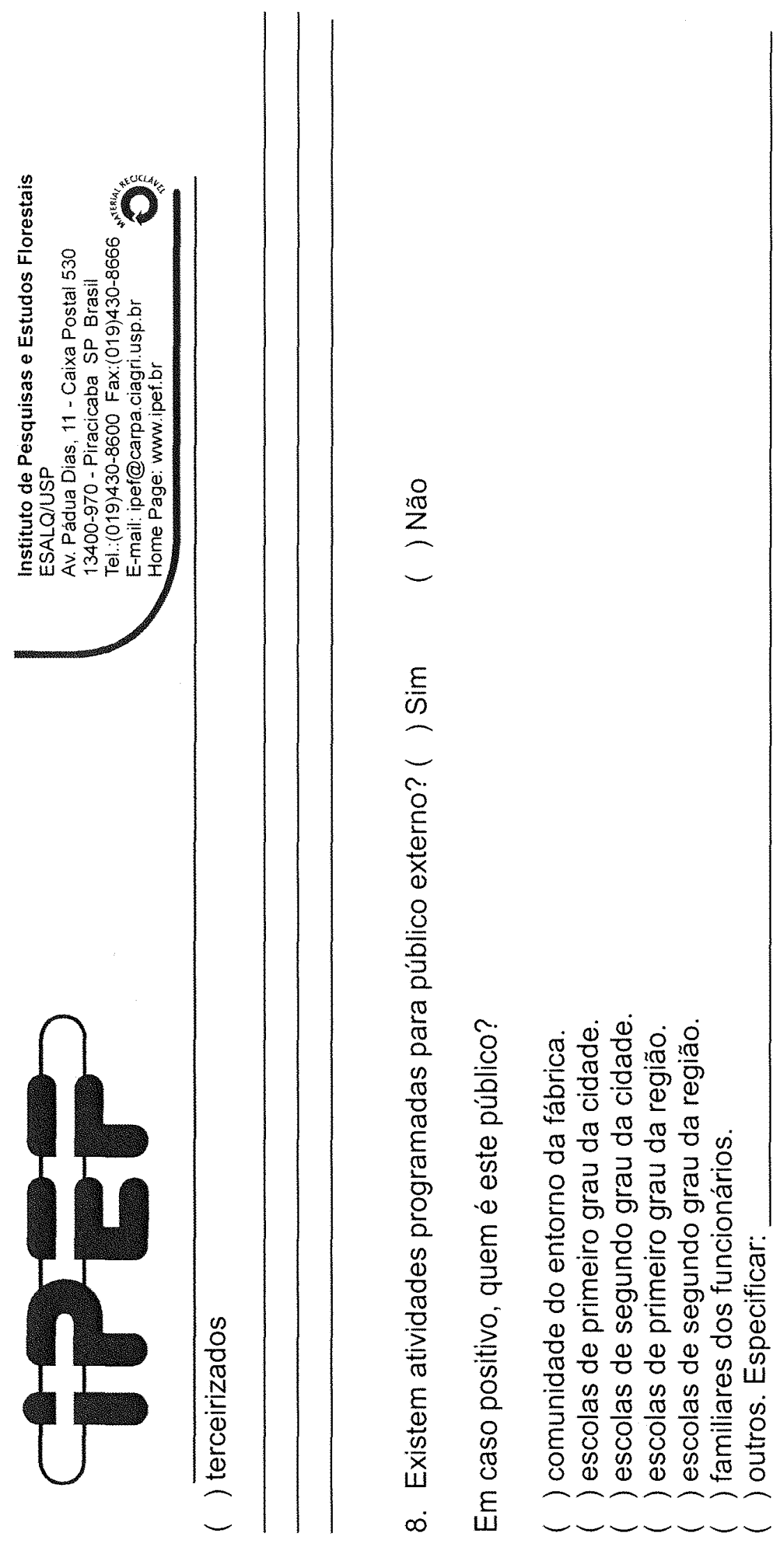




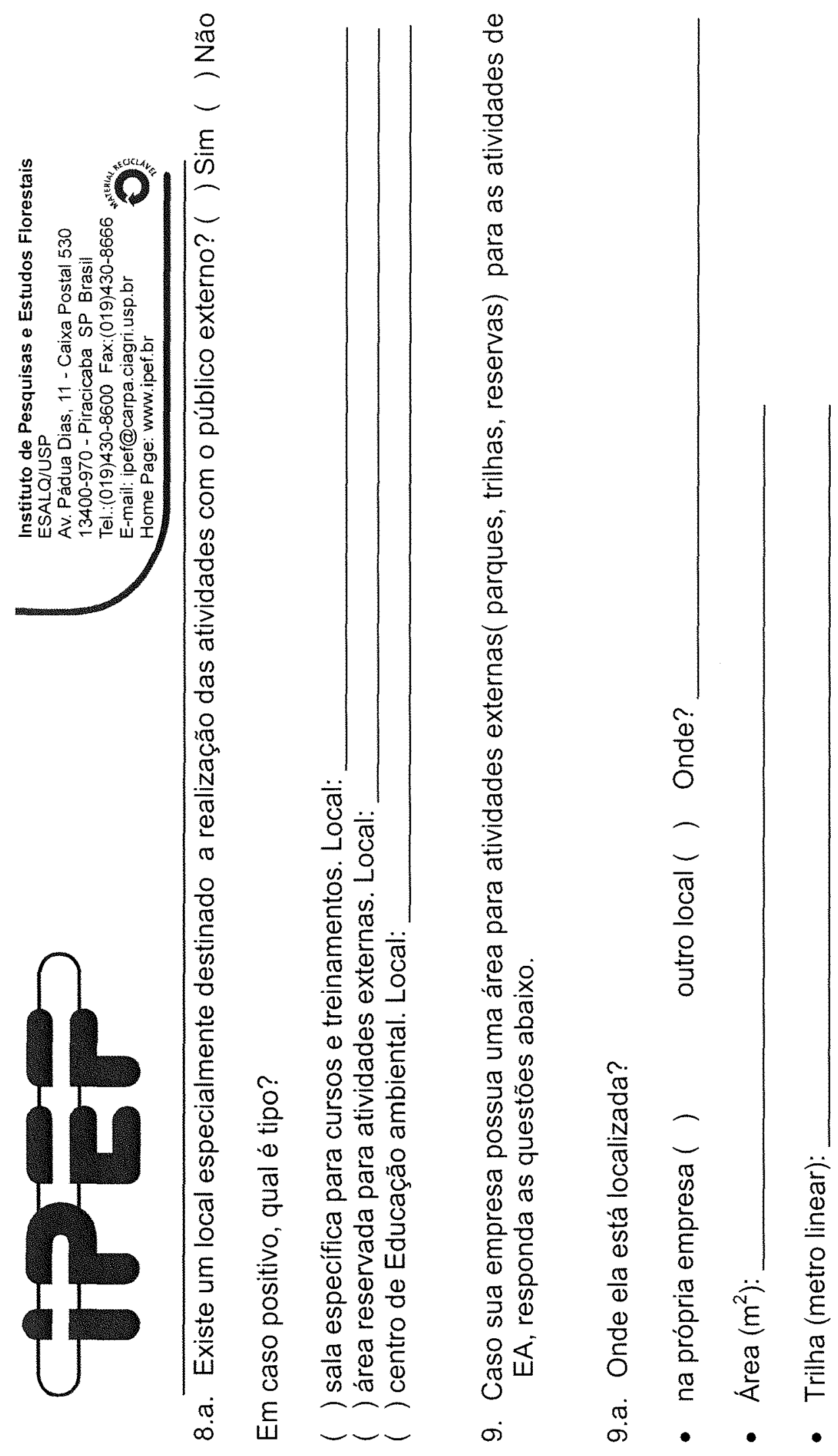



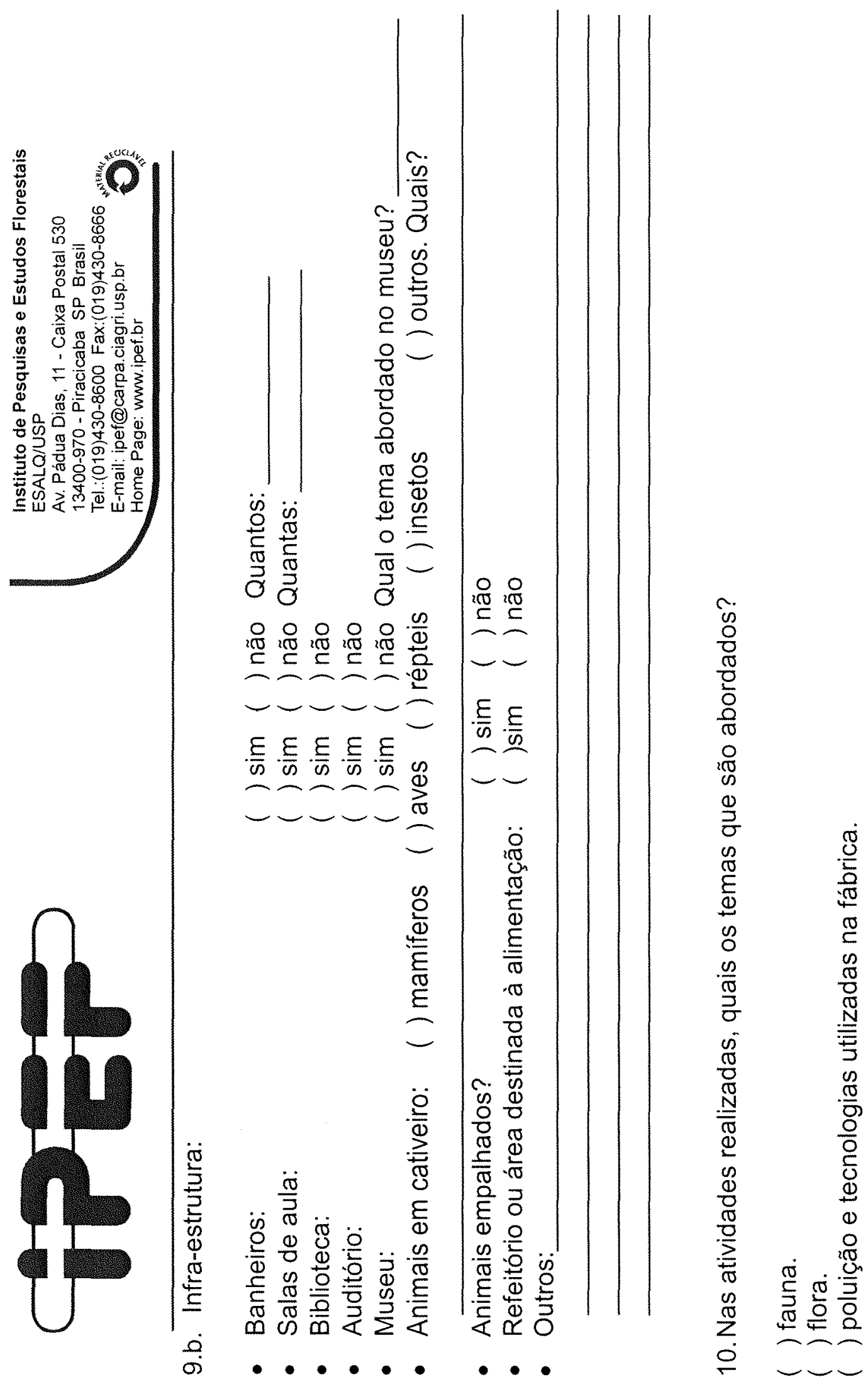


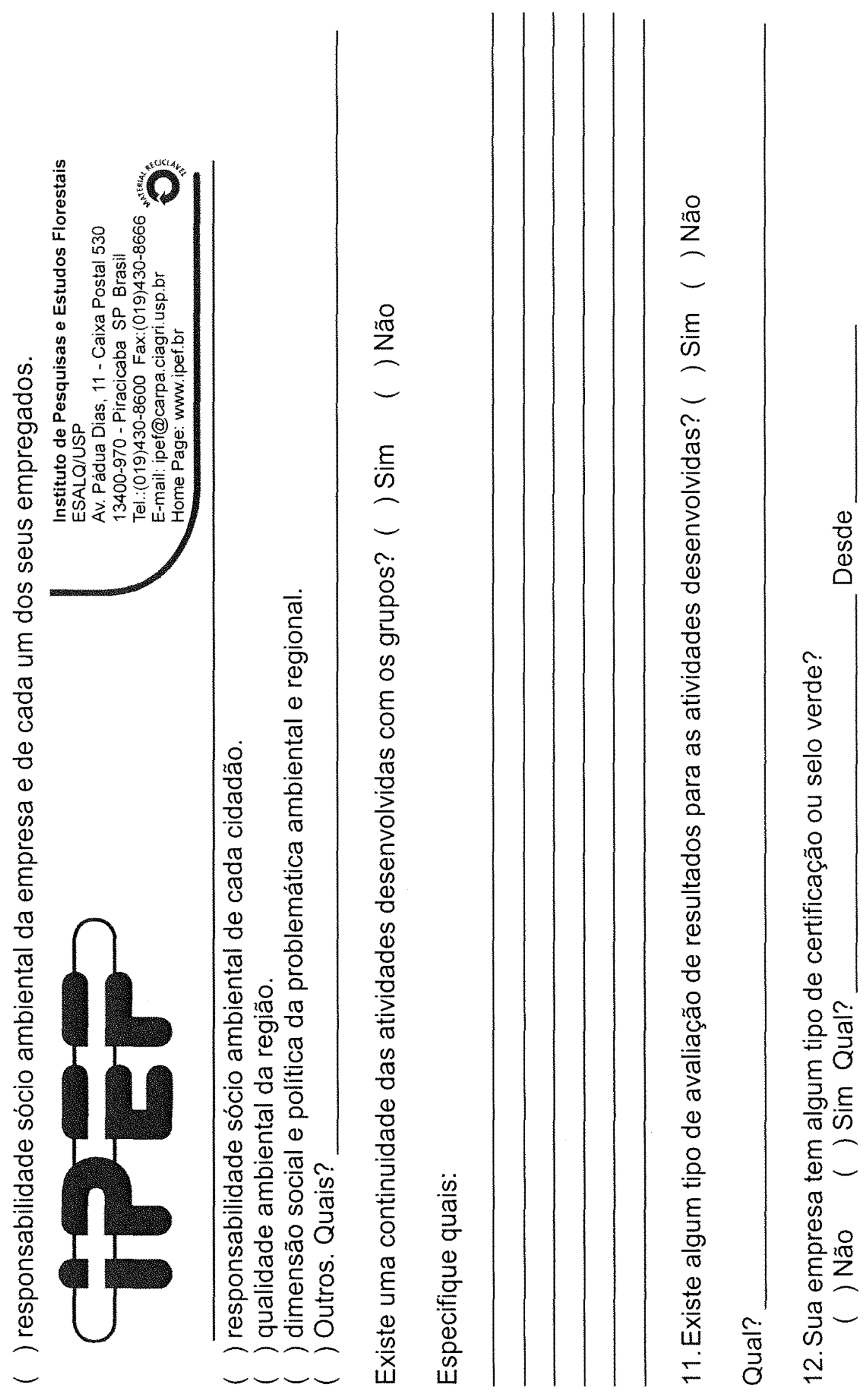



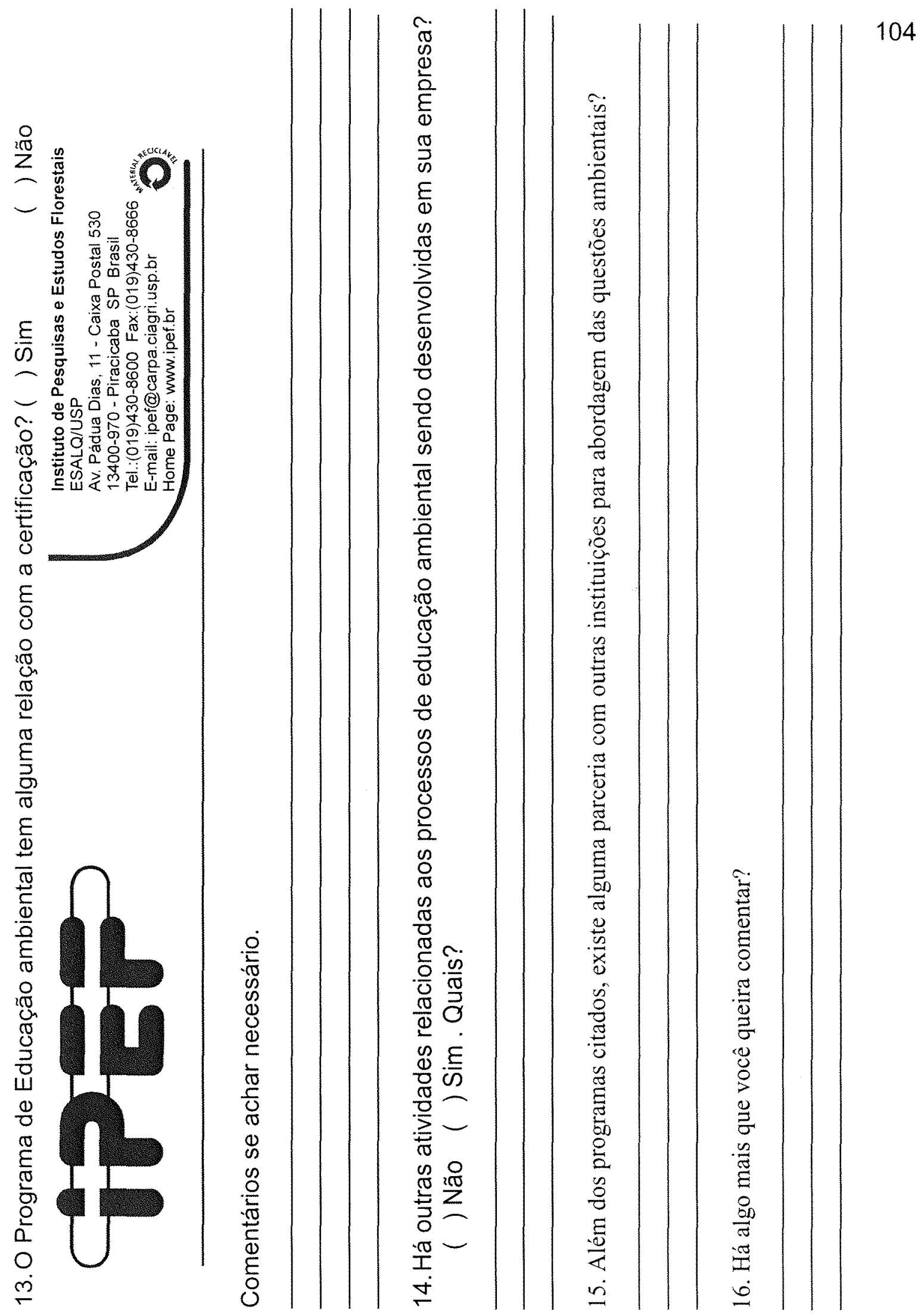


\section{ANEXO C - Empresas associadas ao IPEF - Instituto de Pesquisas Florestais - USP.}

1. Aracruz Celulose S.A.

2. Bahia Sul Celulose S.A.

3. CAF Santa Bárbara LTDA

4. Celulose Nipo - Brasileira S.A - CENIBRA

5. Companhia Suzano de Papel e Celulose

6. Duratex S.A.

7. Eucatex S.A. Indústria e Comércio

8. IKPA - Indústrias Klabin de Papel e Celulose

9. International Paper do Brasil

10. Inpacel Agroflorestal Ltda

11. Lwarcel Celulose e Papel Ltda

12. Pisa Florestal S.A.

13. Ripasa S.A. Celulose e Papel

14. Votorantin Celulose e Papel. 


\section{ANEXO D - Empresas não associadas ao IPEF - Instituto de Pesquisas Florestais - USP.}

1. A.W. Faber Castel S.A.

2. Acesita Energética S.A.

3. Agrominas Empreendimentos Rurais Ltda

4. Bacell S.A.

5. Berneck e Cia

6. Cambará S.A. - Produtos Florestais

7. Caxuama S.A. Reflorestamento

8. Celamr - Celulose Maranhão S.A.

9. Copener Florestal Ltda

10. Florestas Rio Doce

11. Flosul Indústria e Comércio de Madeiras Ltda

12. Gerdau S.A.

13. Igara Papéis e Embalagens Ltda

14. Irani Agroflorestal S.A

15. Jari Celulose S.A.

16. Manasa - Madeireira NacionalS.A.

17. Masisa do Brasil

18. Melhoramentos de São Paulo Arbor

19. Modo Batistella Ref. S. A.

20. Nobrecel S.A. - Celulose e Papel

21. Orsa Celulose Papel e Embalagens Ltda

22. Pains Florestal S.A.

23. Palcas do Paraná S.A.

24. Plantar S.A

25. Quinvalle

26. RAA - Reflorestadora Água Azul

27. Rigesa Celulose, Papel e Embalagens Ltda 
28. Satipel Minas Industrial Ltda

29. SQM Brasil Ltda

30. Swedish Match do Brasil S.A.

31. Tafisa Brasil S.A.

32. Tanagro S.A.

33. Terranova Brasil Ltda

34. Trombine Florestal S.A.

35. $\quad V \&$ M Florestal Ltda

36. Veracel Celulose S.A. 


\section{ANEXO E - Empresas associadas a BRACELPA - Associação Brasileira de Celulose e Papel - 2000.}

1. Adamas SA Papéis e Papelões Especiais

2. Adami SA Madeiras

3. Ahlstrom Papéis Ltda

4. Aracruz Celulose SA

5. Arjo Wiggins Ltda

6. Bacraft SA - Indústria de Papel

7. Bahia Sul Celulose SA

8. Cambará SA - Produtos Florestais

9. Cartonifício Valinhos SA

10. CBP Central Brasileira Comércio e Indústria de Papel Ltda

11. Celulose Irani SA

12. Celulose Nipo-Brasileira SA - Cenibra

13. Cia Indústrias Brasileiras Portela

14. Cia Santista de Papel

15. Cia Suzano de Papel e Celulose

16. Citroplast - Indústria e Comércio de Papéis e Plásticos Ltda

17. Cocelpa - Cia de Celulose e Papel do Paraná

18. Copapa - Cia Paduana de Papéis

19. CVG - Cia Volta Grande de Papel

20. Facepa - Fábrica de Celulose e Papel da Amazônia SA

21. Fernandez SA Indústria de Papel

22. Ibema - Cia Brasileira de Papel

23. IKPC - Indústria Klabin de Papel e Celulose SA

24. Indústria de Papel Gordinho Braune Ltda

25. Indústrias Klabin SA

26. Inpacel - indústria de Papel Arapoti SA

27. International Paper do Brasil Ltda 
28. IPB - Indústria de Papeias da Bahia Ltda

29. Jarcel Celulose SA

30. Klabin Bacell SA

31. Klabin Celucat

32. Klabin Embalagem SA

33. Klabin Kimberly

34. Klabin Papéis

35. Klabin Ponsa SA

36. Klabin Riocell SA

37. Limeira SA Indústria de Papel e Cartolina

38. Lwarcel Celulose e Papel Ltda

39. MD Papéis Ltda

40. Madeireira Miguel Forte SA

41. Manikraft Guaianazes Indústria de Celulose e Papel

42. Melhoramentos Papéis Ltda

43. Nobrevel SA - Celulose e Papel

44. Norske Skog Klabin

45. Orsa Celulose, Papel e Embalagem SA

46. Papirus Indústria de Papel SA

47. Pisa - Papel de Imprensa SA

48. Rigesa Celulose, Papel e Embalagens Ltda

49. Ripasa SA Celulose e Papel

50. Santher - Fábrica de Papel Santa Therezinha SA

51. Schweitzer - Mauduit do Brasil

52. Trombini Papel e Embalagens SA - Div Cel e Papel

53. Veracel Celulose SA

54. Votorantim Celulose e Papel AS 


\section{ANEXO F - Descrição sucinta dos programas de educação ambiental desenvolvidos pelas empresas.}

\section{Aracruz Celulose S.A.}

O programa de educação ambiental da Aracruz Celulose S.A. compreende um elenco de ações desenvolvidas pelas empresas do grupo Aracruz que objetivam levantar informações relevantes à sensibilização e conscientização de seus membros de modo a poderem contribuir para a proteção ambiental.

A atuação é realizada através de nichos já existentes em diversas áreas da empresa. Aproveitando-se os momentos oportunos para inserção de conteúdos através de módulos tornando o processo integrado e menos oneroso.

No trabalho com o público externo atua-se também através de intervenção por nichos, com programas da própria empresa. O Programa Bons Vizinhos, o de parceiros externo (Mosteiro Zen Morro da Vargem) ou intervenções diretas como a "Educação Ambiental para Fomentados" envolveram atendimento externo com consultorias, cursos e palestras. Desenvolveu-se também um programa de educação ambiental para o sul da Bahia.

\section{A.W. Faber Castell S.A.}

O trabalho de treinamento em educação ambiental nesta companhia foi desenvolvido por uma empresa de consultoria ambiental.

A metodologia de trabalho utilizada constituiu-se de 5 (cinco) fases: conhecer, admirar, amar, respeitar e conservar para preservar a natureza.

Entre os meses de março a maio de 2001, durante o curso de capacitação dos professores, foram implementados os trabalhos nas escolas 
do municipio. No mês de junho de 2001 a coordenação da empresa de consultoria e a Faber Castell, em parceria com a Secretaria da Educação e Cultura do Município de Prata - MG, realizaram o "10 Simpósio de Educação Ambiental de Prata, onde se registrou a presença de 706 participantes e um número significativo de alunos de escolas municipais, que colaboraram na montagem dos projetos de cada escola e estão engajados com os mesmos". (Faber Castell, ago 2001)

As atividades relacionadas à continuidade do processo estão em fase de elaboração e serão definidas de acordo com as exigências do FSC (Forest Stewardship Council), órgão certificador de unidades florestais exploradas por empresas, no qual a Faber Castell é certificada desde 1999. A empresa está elaborando um Plano de Trabalho Florestal 2001/2002 que é responsável pela implementação da política ambiental dos projetos florestais de Prata, MG.

A proposta seguinte é criar-se um grupo de estudos com 0 envolvimento de professores da comunidade, oferecendo apoio técnico, palestras ministradas por profissionais, e o acompanhamento de consultoria especializada.

Outras atividades ambientais assumidas pela Faber Castell em seus Parques Florestais em Prata - M.G. são monitoramentos da fauna, da qualidade de água, da conservação dos solos e levantamentos florísticos, todos em parceria com outras instituições.

Os principais objetivos do programa traçado pela empresa, são busca contínua por melhor qualidade de seus serviços e produtos, e um melhor relacionamento entre colaboradores, prestadores de serviços e comunidade. Procura-se, assim, contribuir para amenizar os diversos problemas ambientais existentes no município de Prata e proporcionar melhor qualidade de vida para a população e público envolvido nas diversas atividades da empresa. 


\section{Bahia Sul Celulose S.A.}

O programa de educação ambiental "Projeto Sementeira" foi elaborado pela própria empresa, e contou com a participação da ONG Fundação Relictus. O programa é executado nas próprias escolas que participam do projeto, uma vez que não há um centro específico de educação ambiental. $O$ projeto tem parceria com o BNDES (Banco Nacional de Desenvolvimento Econômico e Social), com as Secretarias de Educação Estadual e Municipal, e com além a Fundação Relictus acima citada. Em 2001 o programa foi implantado nos municípios de Alcobaça, Caravelas e N. Viçosa e tem como meta estender-se a várias localidades do extremo sul baiano.

O projeto consiste na capacitação de professores do ensino fundamental da rede pública, através de treinamentos que incluem a distribuição de cartilhas didáticas, contendo questões sobre cidadania e meio ambiente, que serão repassadas aos seus alunos.

Os professores e alunos são convidados a participar de visitas a trilhas ecológicas situadas em áreas da empresa com o objetivo de sensibilização e conhecimento "in loco" da diversidade biológica local. Outra atividade realizada é uma exposição onde os participantes têm a oportunidade de exibir os trabalhos desenvolvidos. Em todas as fases de implementação do projeto são realizados nas escolas, levantamentos, que possibilitam uma fase final de avaliação de sua eficácia.

No decorrer do processo, é feito, com os professores uma avaliação, do treinamento com os alunos do "Projeto Sementeira". Esta avaliação ocorre na forma de trabalhos escolares, sob coordenação dos professores.

A avaliação de resultados é feita através da eficácia das ações propostas. No entanto a coordenação do projeto faz o seguinte comentário: 
"Nós entendemos ser de fundamental importância a avaliação de efetividade dos projetos de Educação ambiental e inclusive fazemos isso. No entanto, temos dificuldade para obtenção de referências de outros trabalhos nesse sentido, o que poderia nos sugerir melhorias para a avaliação que realizamos aqui".

\section{CAF Santa Bárbara Ltda.}

No Programa Regular de Educação Ambiental da CAF são desenvolvidos, regularmente, trabalhos em conjunto com a Superintendência Regional de Ensino de Divinópolis e com as escolas municipais e estaduais dos municípios de Abaeté, Bom Despacho, Luz, Martinho Campos e Quartel Geral no Estado de Minas Gerais. A programação é realizada com alunos das $6^{\mathrm{a}}$ séries do ensino fundamental

A escolha pelas sextas séries deu-se após consulta a especialistas que alegam que a faixa etária compreendida entre 12 e 14 anos envolve uma fase da vida das crianças onde estão sendo firmadas a responsabilidade e a consciência de vários aspectos da realidade, dentre eles o Meio Ambiente. Além disso, o conteúdo curricular nesse estágio abrange muitos assuntos relacionados às questões ambientais.

Cada turma visita o centro de educação ambiental duas vezes ao ano e o coordenador do programa visita a escola uma vez nesse período, discutindo com os alunos o diagnóstico ou a situação ambiental da escola. $O$ centro de educação ambiental também recebe visitas de outros estudantes, da comunidade em geral e membros de entidades públicas, privadas e ONG's.

No periodo de férias escolares realiza-se um programa de educação com todos os funcionários de empresas da região de Bom Despacho. Procurase conscientizá-los para que identifiquem, solucionem e reduzam problemas que prejudiquem o meio ambiente, além de despertar-Ihes uma visão crítica para o combate à poluição e ao desperdício em suas atividades de rotina. 
A avaliação e monitoramento do programa são realizados de maneira objetiva. Formulários específicos demonstram os graus de aprendizagem e satisfação dos participantes.

Há também a realização de cursos, seminários e também, alguns projetos específicos em andamento tais como: reciclagem de latas de alumínio nas escolas e levantamento entorno-faunístico nas áreas do CEAM - Centro de Educação ambiental

Em 1996 o trabalho desenvolvido foi condecorado com Menção Honrosa no Prêmio Nansen Araújo da FIEMG que identificou as melhoras parcerias entre empresas e escolas públicas nos trabalhos de educação ambiental. (CAF Santa Bárbara, agosto 2001)

\section{CENIBRA - Celulose Nipo - Brasileira S.A}

O projeto Escola da Vida foi desenvolvido em 1996, em conjunto com a ONG Fundação Relictus de Ipatinga. O programa é executado por uma empresa contratada, que realiza as atividades com os alunos do ensino fundamental, numa área reservada para atividades externas, denominada Fazenda Macedônia.

O programa consiste em um treinamento para educadores ao longo de quatro módulos, cada um explicitando conceitos ecológicos específicos, posteriormente repassados para os alunos em forma de atividades pedagógicas e artísticas.

O Relatório Social da BRACELPA de 2000 (p. 14), comenta sobre o Projeto Mutum que tem por objetivo reintroduzir na natureza aves ameaçadas de extinção.

"Esta foi a primeira experiência de reintrodução de aves na natureza, com resultados positivos, mostrando o sucesso de uma parceria entre uma das associadas à Bracelpa e uma ONG. Localizada à margem direita do Rio Doce, nos municipios de Bugre e Ipaba, em Minas 
Gerais, a Fazenda Macedônia, onde se realiza o Projeto conta com área total de aproximadamente três mil hectares, dos quais cerca de $50 \%$ estão cobertos com vegetação nativa. O restante está plantado com eucalipto, além de conter um projeto de agricultura social em parceria com a Prefeitura e o Sindicato dos trabalhadores Rurais de Ipaba."

\section{Duratex S.A}

O programa inicial de educação ambiental era o denominado "pic-nic na Floresta", onde parentes de funcionários participavam de trilhas e banhos de rio nas áreas florestais de Botucatu, Itapetininga e Agudos, Estado de São Paulo. A demanda foi crescendo e em 1996, houve o consenso de unificar o programa num único centro de visitantes. Decidiu-se por Agudos, interior de São Paulo, onde já havia a chamada "Área de Vivência Ambiental - Piatan", com um museu, um criadouro conservacionista, trilhas e área de lazer.

A Duratex é uma empresa voltada para a exportação e como tal tem por objetivo demonstrar aos seus clientes sua preocupação em repor à natureza todas as árvores cortadas. Portanto ela corta somente na proporção em que planta.

A empresa não considera como um programa de educação ambiental as atividades realizadas, pois sabe que recebendo crianças somente uma vez ano não se desenvolve um processo educativo que possa ser monitorado.acompanhar. O que ela admite é possuir um espaço próprio para atividades de educação ambiental, uma ferramenta a mais para o ensino que pode ser utilizada pelos professores.

A Duratex oferece monitor, lanche completo e material de divulgação. Compete à escola o transporte, a definição dos pontos que serão discutidos na visita e a solicitação do local, bem como a seguranças dos alunos. 


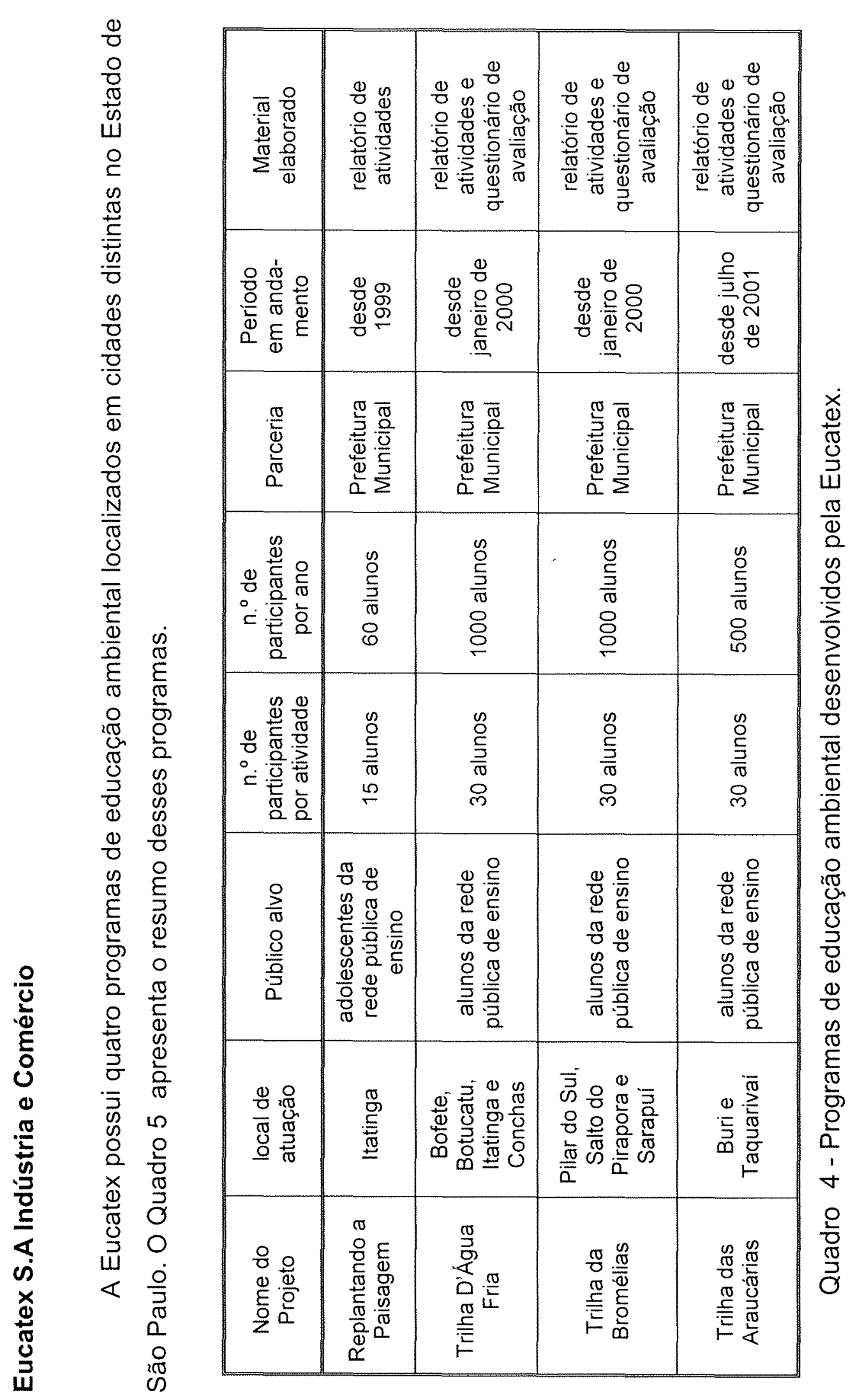




\section{IKPA - Indústrias Klabin de Papel e Celulose}

A Klabin implantou em Monte Alegre, Estado do Paraná, um Centro de Interpretação da Natureza, e possui um programa, no parque ecológico, que baseia-se em visitas auto orientativas, tendo freqüência de cerca de 30.000 visitantes ao ano, sendo composto de estudantes em cerca de $50 \%$ desse total. Essa demanda é originária do pais e do exterior.

Junto a esse Centro há criadouros para reprodução de espécies da fauna regional, extintas ou ameaçadas, para posterior soltura nas florestas da Klabin. Através dos trabalhos desenvolvidos nesta área por especialistas da empresa, apoiados por universitários e pelo IBAMA, já foram identificadas 322 espécies de aves, algumas delas raras e ameaçadas de extinção.

Mamíferos como o tamanduá bandeira, o lobo guará, a lontra e a onça parda, encontram refúgio nas florestas da Klabin.

Com o programa de preservação da fauna, já são encontrados, em grande número, os macacos-prego, bugios, capivaras, catetos, queixadas, três espécies de veado, felinos de menor porte como a jaguatirica, o gato-do-mato e pequenos mamíferos como a cotia e o quitai, entre outras espécies, num total de 50 mamíferos identificados até o momento". (Industria Klabin de Papel e Celulose S.A., 2001).

\section{International Paper do Brasil. S.A}

A International Paper desenvolve seu programa de educação ambiental, denominado "Passeio no Parque", no Parque Florestal International Paper, localizado em Mogi - Guaçu, Estado de São Paulo, e o público alvo consiste em estudantes de ensino fundamental e médio da rede pública da cidade e região de Mogi - Guaçu. O programa atendeu, em 1999, cerca de 
1500 alunos. As cidades participantes foram: Itapira, Estiva Gerbi, Mogi - Mirim e Mogi - Guaçu, todas localizadas no interior do Estado de São Paulo.

O programa foi elaborado pela própria empresa e sempre conta com consultorias de uma coordenadora pedagógica para aperfeiçoamento das atividades. Todos os funcionários envolvidos no programa têm outras funções dentro da empresa, não havendo, portanto, estrutura para elaboração de novos projetos todos os anos.

Em 2001 foram programadas visitas de 21 escolas ao Parque Ecológico. Destas, poucas trabalham a Educação ambiental na perspectiva de uma interação de todos os seres da natureza. Há uma visão antropocêntrica.

Nas atividades que são desenvolvidas incluem-se temas relacionados à produção de papel, produção de mudas de eucalipto, cultura cabocla, cultura indígena, proteção florestal, coleta seletiva de lixo, ciclo da água, criação de abelhas e cultura do homem da Amazônia.

\section{Inpacel - Indústria de Papel Arapoti S.A}

A Inpacel desenvolve um programa de educação junto às escolas do município de Arapoti, Estado do Paraná, dirigido, principalmente, para alunos da primeira a quarta séries do ensino fundamental. O programa atendeu, em 2000, cerca de 1000 alunos e a previsão para 2001 era de receber 1200 alunos das escolas municipais e também estender o programa a escolas estaduais e particulares de Arapoti.

O local de atuação é o Parque Florestal Inpacel em Arapoti, onde está instalado o laboratório ambiental e o museu com animais taxidermizados encontrados na região. O programa está em andamento desde o início de 2000. Foi elaborada uma apostila para professores e cartilha sobre a araucária.

Os alunos das terceiras séries fazem uma visita durante o ano letivo, desdobrando-se em outra no ano seguinte, aprofundando os temas tratados 
anteriormente. O programa envolve como atividades de avaliação, redações, questionários e conversas informais com alunos e professores.

Em datas comemorativas como Semana do Meio Ambiente e o Dia da Árvore (entre outros), são realizados concursos em parcerias com as escolas municipais, estaduais e particulares premiando os principais trabalhos apresentados.

O objetivo principal do programa é informar e motivar funcionários, familiares e a comunidade quanto à responsabilidade ambiental, criando-se padrões de conduta voltados à conservação do meio ambiente $\mathrm{e}$ conseqüentemente a melhoria da qualidade de vida. As ações ambientais praticadas pela empresa, são divulgadas criando um canal de comunicação com a comunidade.

\section{Lwarcel Celulose e Papel Ltda.}

A idéia-força do projeto é a profissionalização. O trabalho é realizado com alunos que cursam a oitava série do ensino fundamental e deverá ser executado até o ano de 2001 para que todos os adolescentes que ingressaram na quinta série em 1998 tenham a oportunidade de chegando a oitava série, visitarem as instalações da empresa e conhecer sua realização industrial e social.

São criados, juntamente com os professores, temas para que sejam desenvolvidas redações que obriguem os adolescentes, participantes do projeto, a refletirem sobre o problema.

Foram lançados dois concursos para envolvimento de um número maior de participantes fazendo com que estes percebam o ponto crucial de suas vidas, que é quando estão deixando o ensino fundamental e partindo para o ensino médio. A preocupação da empresa foi a de fazer com que os participantes se coloquem alertas para vislumbrar as perspectivas e horizontes que podem ser abertos como oportunidades para a vida profissional. 
Dos dois concursos, um deles é o de redação e é obrigatório (ponto muito discutido na fase inicial), pois conta como pontuação na matéria de português (decisão instituída pela Diretoria de Ensino). O outro é um concurso de fotografias e a participação é opcional. A premiação é um curso (línguas ou informática) pago por um ano pela empresa para cada um dos ganhadores das duas melhores redações e máquinas fotográficas par os cinco melhores trabalhos em fotografias. 15 .

Rigesa Celulose, Papel e Embalagens Ltda.

Em 1974, a American Forest Foundation criou o PLT-Project Learning Tree (Projeto Aprendendo com a Árvore ou PACA).

Este projeto expandiu-se para diversos paises como Canadá, Finlândia, México, Suécia, Japão e Brasil. As unidades da Rigesa em Três Barras, Estado de Santa Catarina, foram as primeiras a implantar o PACA no Brasil.

O projeto PACA não educa somente baseando-se em árvores, mas também aborda questões ambientais relativas ao ar, água, solo, vegetais e animais, e suas inter-relações. O objetivo do PACA é demonstrar que é possivel harmonizar o desenvolvimento social e econômico da nossa sociedade, que tem como característica a constante agressão do homem à natureza.

São mais de 1.100 professores treinados pela Rigesa. O PACA está presente em mais de 17 escolas, atingindo aproximadamente 25.000 alunos numa população de 150.000 habitantes. Em 2001 deverá alcançar o número significativo de 200 escolas.

O primeiro treinamento foi dado em 1995, em São Francisco do Sul, Estado de Santa Catarina, por duas professoras credenciadas no estado da Virgínia, nos Estados Unidos. Nesta primeira etapa, 75 professores da rede 
estadual e municipal de ensino de Três Barras foram habilitados e deram início ao PACA - Projeto Aprendendo com a Árvore.

Ainda em 1995, a Escola Básica Municipal "Guita Federmann" de Três Barras, foi a primeira escola a aplicar o PACA. O projeto contribuiu para um aumento nos números de freqüência e aprovação dos alunos da referida escola. Além de melhorar o desempenho das aulas ministradas pelos professores, desenvolver a interdisciplinaridade, a pesquisa teórica baseada em experiências e a experiência de campo, estimulando a aprendizagem, a criatividade e a autonomia consciente dos educandos com relação a conteúdos originais que proporcionam ativa interação entre professores e alunos através de diálogos e debates.

Em 1996 o projeto expandiu-se para as demais escolas de Três Barras, envolvendo aproximadamente 3.000 alunos e a comunidade, que se tornou parceira do projeto, pois uma das principais metas do PACA é o envolvimento e comprometimento da comunidade onde está inserida a escola.

Em 1997 o projeto expandiu-se para o município vizinho de Canoinhas, onde passou a ser desenvolvido em mais de 20 escolas, envolvendo cerca de 4.000 alunos e, conseqüentemente, seus familiares e a comunidade em geral.

Sucessivamente o PACA foi tomando espaço em outros Municípios. Os sete Municipios que hoje aplicam o PACA são: Três Barras, Canoinhas, Major Vieira, Mafra, Porto União, Bela Vista do Toldo e Irineópolis. ${ }^{16}$ 


\section{Ripasa S.A Celulose e Papel}

A empresa possui um programa de educação ambiental, por ela elaborado, que é aplicado em dois Parques Florestais distintos.

No Municipio de Ibaté, centro do Estado de São Paulo, encontra-se o Parque Florestal Fortaleza, com uma área de 5603 ha. Neste parque é desenvolvido, desde 1987, o programa de educação ambiental "Conhecer para Preservar", que recebe alunos e professores do ensino fundamental, das cidades de Ibaté, Araraquara e São Carlos, e familiares dos funcionários da empresa. São utilizados como recursos didáticos principais, a "Trilha Interpretativa da Natureza" e o "Núcleo Faunístico Abrahão Zarzur", que foi incorporado ao programa em 1994. Assim, é realizado um programa permanente de estudos do meio, com o intuito de transmitir noções sobre educação voltada ao meio ambiente (RIPAX, s.d.).

O programa atende crianças da $6^{\mathrm{a}}$ série, com 35 a 40 alunos por atividade. O número de participantes anual é de 5000. Eventualmente a Prefeitura do Municipio fornece ônibus para transporte dos jovens. O programa tem como material educativo um vídeo que fala sobre o parque e a empresa. Outro público atingido é o de professores, com um número anual de 30 participantes e a intenção é prepará-los para a visita ao Parque Florestal.

No início de cada ano, a RIPASA entra em contato com a delegacia de ensino de Araraquara procurando interar-se dos principais temas que serão tratados com os alunos. Dessa forma os trabalhos realizados são na trilha são consonantes com os conteúdos teóricos abordados em sala de aula. $\mathrm{O}$ objetivo principal é atender as escolas estaduais da região, fornecendo transporte para os alunos, acompanhamento de monitor durante a trilha e lanche no final do passeio. Durante a caminhada na trilha, os alunos podem observar três tipos distintos de florestas, alguns afloramentos de rochas e um rio. 
Ibaté atende também grupos de terceira idade. O número anual de participantes é de, aproximadamente, 3000 pessoas.

O segundo parque está localizado em lbiti e também atende crianças da $6^{\text {a }}$ série. O número anual de participantes é de 100. A prefeitura local fornece ônibus e o programa está em andamento desde 1998.

O enfoque principal é atender o maior número possível de visitantes. O programa não tem a intenção de formar educadores ambientais. Eles se colocam como apoio complementar às atividades dadas na escola. Não é esclarecido o motivo pelo qual escolhem a $6^{\mathrm{a}}$ série como público alvo. A empresa diz contribuir com a educação ambiental propiciando a contemplação de imagens naturais que não podem ser vistas na escola. Eventualmente flexibiliza-se o espaço, destinando-o, por exemplo, às crianças de Americana, além de Ibaté e Araraquara. O programa tem se estendido a várias cidades da região.

\section{Veracel Celulose S.A}

A Veracel possui um programa que é denominado "Conhecendo a Mata Atlântica", que atua desde 1996 atendendo estudantes e professores .

A empresa possui um centro de educação ambiental localizado em Porto Seguro, Estado da Bahia, denominado Estação Vera Cruz, com uma área de aproximadamente 6.069 ha. $O$ Centro possui cinco trilhas interpretativas, sendo a principal constituída de 1.850 metros. O processo de continuidade do programa se dá através de novas à reserva, palestras e cursos de extensão nas escolas e junto às comunidades. $A$ avaliação é feita através de questionários. Os locais de atuação são: Costa do Descobrimento, Porto Seguro, Eunápolis, Belmonte e Santa Cruz da Cabrália. 


\section{REFERÊNCIAS BIBLIOGRÁFICAS}

ABREU, D. Sem ela nada feito! Salvador: Casa da Qualidade, 2000. 100p.

ALVES, R. O amor que ascende a lua. Campinas: Papirus, 2000. 214p.

ARACRUZ CELULOSE S.A. Educação ambiental e relatório social e ambiental. http://www.aracruz.com.br (10 maio 2002).

ARACRUZ CELULOSE S.A. Programa de educação ambiental. rcsa@aracruz.com.br (27 abril 2001).

ARAÚJO, J. A. de. Manual de sistema de gestão ambiental. Piracicaba: Idéia Dois, 1997. 144p.

ASSOCIAÇÃO BRASILEIRA DE CELULOSE E PAPEL - BRACELPA Relatório social. São Paulo, 2000. 16p.

BACHA, C.J.C. O uso sustentável de florestas: o caso Klabin. In: LOPES, I.V.; BASTOS, S.G.; BILLER, D.; BALE, M. (Orgs.). Gestão ambiental no Brasil: experiência e sucesso. Rio de Janeiro: Fundação Getúlio Vargas, 1996. 408p.

BAHIA SUL CELULOSE S.A. Ação social. http://www.bahiasul.com.br (12 maio 2001)

BRAGA, T. Educação ambiental, economia internacional e gestão empresarial, 1994. In: SORRENTINO, M.; TRAJBER, R.; BRAGA, T. Cadernos do III Fórum de Educação ambiental. São Paulo: Gaia, 1995. p.215-224. 
BRUYNE, P.; HERMAN, J.; SCHOUTHEETE, M. Dinâmica da pesquisa em ciências sociais. Rio de Janeiro: Francisco Alves, 1991. 252p.

CALLENBACH, E.; CAPRA, F.; GOLDMAN, L. et al. Gerenciamento ecológico. São Paulo: Cultrix / Amana, 1993. 203p.

CAPRA, F. A teia da vida: uma nova compreensão científica dos sistemas vivos. São Paulo: Cultrix, 1996. 256p.

CASTRO, M. C. Desenvolvimento sustentável e gestão ambiental na formulação de políticas públicas: a experiência do estado do Amapá. Macapá: CEFORH/SEMA, 1998. 114p.

CORTEZ, A, T, C; A política ambiental em indústrias de Rio Claro. Rio Claro: UNICLAR/FAAP/CENAP/Rio MIX, 1997. 119p. (Relatório de pesquisa)

CZAPSKI, S. A implantação da educação ambiental no Brasil. Brasilia: Coordenação de Educação ambiental do Ministério da Educação e do Desporto, 1998. cap.1, p.17-70.

DALLARI, D. Direito de participação. In: SORRENTINO, M. (Org.). Ambientalismo e participação na contemporaneidade. São Paulo: EDUC, 2001. cap.4, p.85-114.

DELORS, J. Educação: um tesouro a descobrir. 2.ed. São Paulo: Cortez, 1999. 288p.

DURATEX S.A. Meio Ambiente. http://www.duratex.com.br (02 maio 2001)

EXAME. Guia Exame de Boa Cidadania Corporativa. São Paulo, n.754, 18 nov.2001. 
FABER CASTELL. Educação ambiental: síntese do treinamento de educação ambiental. cassiano.schneider@faber-castel.com.br (01 Agosto 2001).

FERREIRA, L. C.; VIOLA, E. (Org.) Incertezas de sustentabilidade na globalização. Campinas: UNICAMP, 1996. 331p.

FOREST STEWARDSHIP COUNCIL. http://www.wwf.org.br/fsc (dez. 1999).

GADOTTI, M. Pedagogia da terra. 2.ed. São Paulo: Fundação Petrópolis, 2000. 217p.

GOMES, P. M. Gestão ambiental na esfera do Estado e do mercado: quem regula o quê e por quê. In: QUINTAS, J. S. Pensando e praticando a educação ambiental na gestão do meio ambiente. Brasília: Edições Ibama, 2000. cap.9, p.127-138.

GONÇALVES, C. W. P. Um pouco de filosofia no meio ambiente. In: QUINTAS, J. S. Pensando e praticando a educação ambiental na gestão do meio ambiente. Brasília: Edições Ibama, 2000. cap.2, p.21-37.

GUTBERLET, J. Desenvolvimento desigual: impasses para a sustentabilidade. São Paulo: Fundação Konrad-Adenauer-Stftung, 1998. 109p.

HARMAN, W; HORMANN, J. O trabalho criativo: o papel construtivo dos negócios numa sociedade em transformação. 12.ed. São Paulo: Cultrix, 1990. 233p.

HUNGERFORD, H. R.; PEYTON, R. B. Como construir un programa de educación ambiental. 1.ed. Syntax: C.B.,1992. 59p.

INDÚSTRIA DE PAPEL DE ARAPOTI - INPACEL. Meio ambiente. http://www.international paper.com.br. (18 maio 2001) 
INDÚSTRIAS KLABIN DE PAPEL E CELULOSE. - IKPC. Meio ambiente e educação ambiental. http://www.klabin.com.br (maio de 2001).

INTERNATIONAL PAPER DO BRASIL. Meio ambiente. http://www.internationalpaper.com.br. (05 jun 2001).

LAKATOS, E. M.; MARCONI, M. A. Técnicas de pesquisa. São Paulo: Atlas, 1982. 205p.

LAKATOS, E. M.; MARCONI, M. A. Fundamentos da metodologia científica. 3.ed. São Paulo: Atlas, 1991. 270p.

LAYRARGUES, P. P. A resolução de problemas ambientais locais deve ser um tema-gerador ou a atividade-fim da educação? In: REIGOTA, M. Verde cotidiano: o meio ambiente em discussão. Rio de Janeiro: DP\&A, 1999. p.131-148.

LÜDKE, M; ANDRÉ, M. E. D. A. Pesquisa em educação: abordagens qualitativas. São Paulo: E.P.U., 1986. 99p.

LWARCEL CELULOSE E PAPEL LTDA. Meio ambiente. http://lwart.com.br. (02 jun.2001).

MAIMON, D. Passaporte verde: gestão ambiental e competitividade. Rio de Janeiro: Qualitymark, 1996. 120p.

MARINHO, P. A pesquisa em ciências humanas. Petrópolis: Vozes, 1980. $171 \mathrm{p}$.

MARTINE, G. (Org.) População, meio ambiente e desenvolvimento. Campinas: UNICAMP, 1993. 207p. 
MEDINA, N. M. Breve histórico da Educação ambiental. In: PADUA, S.M; TABANEZ, M. F. Educação ambiental: caminhos trilhados no Brasil. Brasília: Pax/lpê, 1997. 283p

MENDONÇA, R. A experiência na natureza segundo Joseph Cornnel. In: SERRANO, C. (Org.). A Educação pelas pedras: ecoturismo e educação ambiental. São Paulo: Chronos, 2000. 189p.

MOGGI, J.; BURKHARD, D. O espírito transformador: a essência das mudanças organizacionais do século XXI. São Paulo: Infinito, 2000. 135p.

MORIN, E. Os sete saberes necessários à educação do futuro. São Paulo: Cortez, 2000. 118p.

MOURA, L. A. A. Qualidade e gestão ambiental: sugestões para implantação das normas ISO 14000 nas empresas. 3.ed. São Paulo: Juarez de Oliveira, 2002. 331p.

PADUA, S. M.; TABANEZ, M. F. (Orgs.). Educação ambiental: caminhos trilhados nos Brasil. Brasília: Instituto de Pesquisas Ecológicas, 1997. 283p.

PANAYOTOU, T. Mercados verdes: a economia do desenvolvimento alternativo. Rio de Janeiro: Nórdica, 1994. 175p.

REIGOTA, M. Meio ambiente e representação social. São Paulo: Cortez, 1995. 87p.

RICHARDSON, R. J. Pesquisa social: métodos e técnicas. 3.ed. São Paulo: Atlas, 1999. 333p.

Rigesa Celulose, PAPEL E eMBAlagens ltDA. Projetos sociais. http://www.rigesa.com.br (30 maio 2001) 
RIPASA SA CELULOSE E PAPEL. Meio ambiente. http://www.ripasa.com.br (30 maio 2001).

ROCHA, L.M.; ANDRADE, V. J. Manuais para a capacitação no manejo de unidades de conservação. Bauru: Sociedade Educativa Gaia, 1997. 31p.

SANTA BÁRBARA LTDA - CAF. Centro de educação ambiental. http://www.caf.ind.br. (maio 2001).

SANTA BÁRBARA LTDA - CAF. Programa regular de educação ambiental: Prêmio ambiental von Martius. cafbd@gshnet.com.br (02 jul 2001).

SANTOS, B. S. Pela mão de Alice: o social e o político na pós-modernidade. 3.ed. São Paulo: Cortez, 1997. 348p.

SELLTIZ, C.; JAHODA, M.; DEUTSCH, M.; COOK, S. W. Métodos de pesquisa nas relações sociais. São Paulo: EPU, 1974. 687p.

SORRENTINO, M. De Tbilisi a Thessaloniki: a educação ambiental no Brasil. In: QUINTAS, J. S. Pensando e praticando a educação ambiental na gestão do meio ambiente. Brasília: Edições Ibama, 2000. cap.7, p.105114.

SORRENTINO, M. Educação ambiental e universidade: um estudo de caso. São Paulo, 1995. 263p. Tese (Doutorado) - Faculdade de Educação, Universidade de São Paulo.

SORRENTINO, M. Vinte anos de Tbilisi, cinco da Rio 92: a educação ambiental no Brasil. Debates Sócio Ambientais, n.7, p.3-5, jun/set. 1997a.

SORRENTINO, M. Meio ambiente e grandes empresas: otimismo do discurso, pessimismo da ação. In: SEMINÁRIO SOBRE A ECONOMIA MINEIRA, Belo Horizonte, 1995. Anais. Belo Horizonte: CEDEPLAR/UFMG, 1995. 
SOUZA, L. R. O papel da educação ambiental em empresas. http://techoje.com.br. (05 maio 2000).

VALLE, C. E. Qualidade ambiental: como ser competitivo protegendo o meio ambiente: como se preparar para as normas ISO 14000. São Paulo: Pioneira, 1995. 117p.

VERACEL CELULOSE SA. Meio ambiente / programa estação Vera Cruz. http://www.veracel.com.br. (29 maio 2001).

VIEZZER, M., RODRIGUES, C.L., MOREIRA, T. Enfoque de educação popular e gênero - somos todos sujeitos e não objetos. In: TRAJBER, R., MANZOCHI, L. H. (Orgs.). Avaliando a educação ambiental no Brasil: material impresso. São Paulo: GAIA, 1996. 226p. 